\title{
História da Matemática e Cinema: \\ $O$ caso da criptografia na introdução do ensino de Álgebra
}

\author{
Fabiana de Souza Bomfim
}

\author{
DISSERTAÇÃO APRESENTADA AO \\ INSTITUTO DE MATEMÁTICA E ESTATÍSTICA DA \\ UNIVERSIDADE DE SÃO PAULO \\ COMO REQUISITO PARCIAL PARA \\ OBTENÇÃO DO TÍTULO DE \\ MESTRE EM CIÊNCIAS NO \\ PROGRAMA DE MESTRADO PROFISSIONAL EM \\ ENSINO DE MATEMÁTICA SOB ORIENTAÇÃO DO \\ PROFESSOR DR. ANTONIO CARLOS BROLEZZI
}




\section{História da Matemática e Cinema: \\ O caso da criptografia na introdução do ensino de Álgebra.}

Fabiana de Souza Bomfim 


\section{História da Matemática e Cinema: o caso da Criptografia na introdução do ensino de Álgebra.}

Fabiana de Souza Bomfim

Comissão Julgadora:

$>$ Prof. Dr. Antonio Carlos Brolezzi (orientador) - IME-USP

$>$ Prof. Dra.Circe Mary Silva da Silva Dynnikov - IME -USP

$>$ Prof. Dr. Vinício de Macedo Santos FE -USP 


\section{Agradecimentos}

À Deus, por me permitir vivenciar intensamente essa experiência de estudo e por sempre iluminar as minhas escolhas diante de tantas oportunidades que a vida me oferece diariamente.

Ao meu querido avô materno, Cícero Antônio dos Santos, por me contaminar com a sua paixão pela busca constante por conhecimento, pela sua dedicação, companheirismo e amor incondicional . Obrigada por sempre enxergar em mim tanto potencial e me proporcionar experiências inspiradoras sempre. Ao meu querido orientador Brolezzi, pelas aulas e orientações sempre inspiradoras, por estar sempre disposto a ajudar com paciência e alegria. Obrigada por respeitar minhas escolhas, entender minhas limitações e me ajudar a encontrar caminhos de superação. Obrigada por sempre confiar em meu potencial. Sou imensamente grata por sua generosidade durante toda a realização desse trabalho.

À querida professora Barbara Valério, cuja experiência e conversas permitiram que eu ampliasse minhas referências bibliográficas. Agradeço também todas as contribuições maravilhosas que deu ao meu trabalho.

Ao meu amado marido Vinícius, companheiro de todas as horas e momentos e principal incentivador. Sem ele, nada teria acontecido. Obrigada meu amor, por fazer do meu sonho, nosso sonho.

Ao querido Silvio Barini, que de forma muito generosa compartilhou comigo a história de sua trajetória. Obrigada por me inspirar com seus exemplos e por me apoiar nessa trajetória.

À minha querida Roberta Jung coordenadora e amiga, agradeço todo apoio, incentivo e ajuda durante essa jornada.

Agradeço a todos os queridos amigos e professores incríveis que passaram pela minha vida e que me ajudaram de diversas formas a concluir esse trabalho. 
E principalmente aos meus queridos alunos, que são inspiradores sempre! Aprendi muito mais com vocês do que ensinei. Obrigada por me ajudarem a realizar todos os dias o meu sonho de infância: ser professora.

"Educar é impregnar de sentido o que fazemos a cada instante!" 
Como as ciências matemáticas são tão vastas e variadas, é necessário localizar seu cultivo, pois toda atividade humana está ligada a lugares e pessoas."

David Hilbert

\section{RESUMO}

O presente trabalho descreve uma proposta de aprendizagem significativa e contextualizada social e culturalmente na introdução do ensino de Álgebra por meio da utilização do filme Jogo da Imitação (2014), que traz elementos da História da Matemática, em especial da História da Criptografia. A proposta descrita apresenta o cinema como organizador prévio para as aulas de Matemática, em particular de Álgebra, com a finalidade de promover aprendizagem significativa, no sentido de Ausubel, Novak e Hanesian (1980). O trabalho também traz a descrição de atividades nas quais há um uso intencional da História da Matemática na construção do conhecimento para a formação do cidadão criativo, crítico, responsável e participativo, envolvendo professores de matemática e alunos do Ensino Fundamental II de uma escola particular da cidade de São Paulo. O trabalho também descreve a concepção de ensino dessa escola, em que as atividades foram realizadas, a fim de dar a elas o devido contexto.

Palavras-chaves: Criptografia, Aprendizagem significativa; História da Matemática; Cinema; Atitude, Contexto. 


\begin{abstract}
The present work describes a meaningful, socially and culturally contextualized learning approach in the introduction of Algebra teaching through the use of the movie The Imitation Game (2014), which brings elements of the History of Mathematics, especially the History of Cryptography. The proposal described presents the cinema as a previous organizer for Mathematics classes, in particular Algebra, with the purpose of promoting meaningful learning, in the sense of Ausubel, Novak and Hanesian (1980). The paper also describes activities in which there is an intentional use of the History of Mathematics in the construction of knowledge for the formation of a creative, critical, responsible and participative citizen, involving mathematics teachers and Elementary School students from a private school in Sao Paulo City. The paper also describes the conception of teaching of this school, in which the activities were carried out, in order to give them the due context.
\end{abstract}

Key words: Cryptography, Meaningful learning; History of Mathematics; Movie theater; Attitude, Context. 


\section{SUMÁRIO}

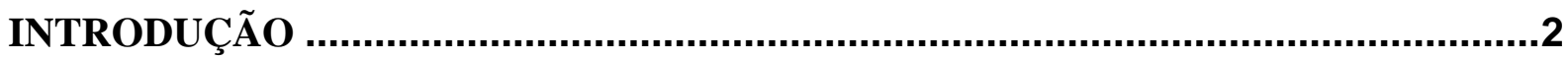

I. APRENDIZAGEM SIGNIFICATIVA

TIPOS DE APRENDIZAGEM ……....................................................................................

ORGANIZADORES PRÉVIOS, DIFERENCIAÇÃO PROGRESSIVA E A

RECONCILIAÇÃO INTEGRADORA....................................................................................11

II. HISTÓRIA NA EDUCAÇÃO MATEMÁTICA ...............................................15

A HISTÓRIA DA MATEMÁTICA COMO UM ESPELHO_.................................................15

A HISTÓRIA DA MATEMÁTICA COMO PINTURA …….............................................17

III. CINEMA E HISTÓRIA DA MATEMÁTICA - NA BUSCA POR UM

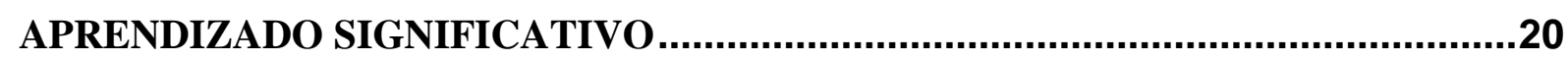

IV. BREVE INTRODUÇÃO DA HISTÓRIA DA CRIPTOGRAFIA........................24

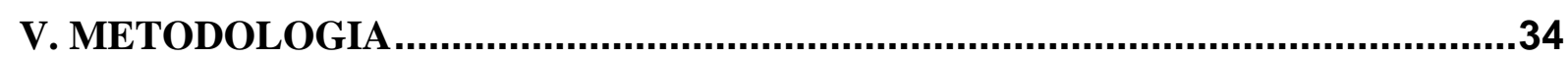

PLANEJAMENTO DA PESQUISA ..............................................................................

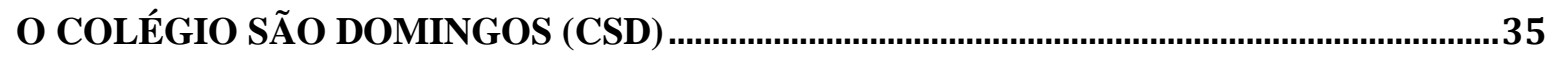

SEQUÊNCIA DIDÁTICA .....................................................................................................39

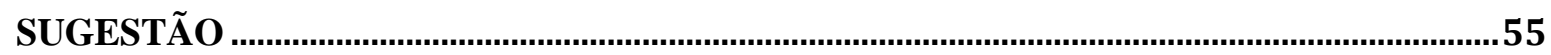

PRINCIPAIS APRENDIZADOS.............................................................................................

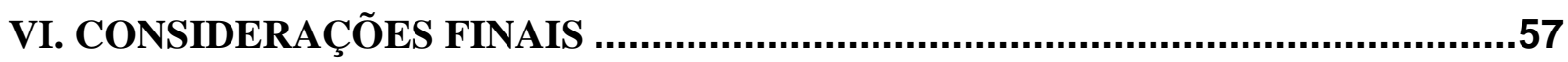

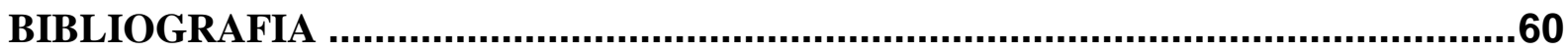

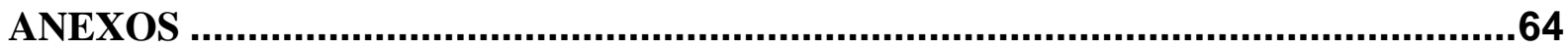

O GANSO QUE JAMAIS GRASNAVA (A HISTÓRIA DA ENIGMA) ..................................64

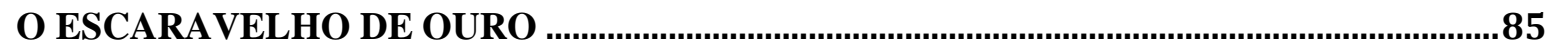

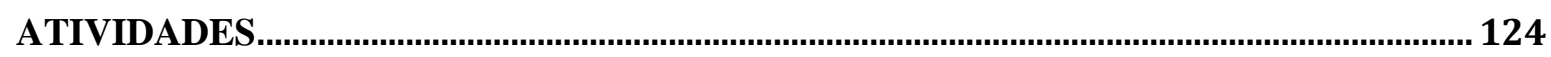




\section{INTRODUÇÃO}

O ensino de Matemática passou por diversas transformações, e cada vez mais estudos analisam tendências que reforçam o importante papel da Matemática no currículo e na vida. $\mathrm{O}$ ensino de Matemática visa formar cidadãos capazes de compreender os processos tecnológicos e sociais de produção, distribuição e consumo de bens necessários à humanidade, por meio da Matemática, conforme já preconizavam no final do século passado os Parâmetros Curriculares Nacionais (PCNs) (1998).

$\mathrm{Na}$ configuração mundial contemporânea, as preocupações se voltam para os problemas ambientais, como a redução de recursos naturais; do crescimento populacional; da pluralidade cultural; das novas prioridades da ciência e da tecnologia; entre outros, que trazem impactos nos modelos de educação, cultura e desenvolvimento socioeconômico.

Nesse contexto mundial, a Educação está apresentada como agente transformador de uma sociedade plural, e torna-se premente a necessidade de atender as demandas sociais de acessibilidade da educação para todos..

Como campo de pesquisa, a Educação Matemática tem trazido paradigmas de ensino que visam uma educação em matemática em consonância com as ditas humanidades. Assim, a matemática pode assumir seu papel na sociedade, na formação do cidadão, não como uma disciplina à parte, com fim em si mesma. O ensino da Matemática não se limita ao conhecimento formal de definições, resultados, técnicas e demonstrações. Para que os conhecimentos tenham significado, os alunos precisam se apropriar deles, mobilizá-los e utilizá-los em situações diversas que atendam as demandas dessa nova configuração de mundo e sociedade.

No entanto, se por um lado há um senso comum que sinaliza que a "Matemática está em tudo", e se desenvolvem argumentos para justificar a função educacional da disciplina, por outro lado existe um isolamento, manifestado na prática, em relação às demais disciplinas. Tornou-se comum que muitos alunos tenham dificuldades em utilizar os conhecimentos básicos em situações contextualizadas, como podemos observar nos baixos resultados em exames como o Programme for International Student Assessment (PISA), Programa Internacional de Avaliação de Estudantes.

O PISA é uma avaliação aplicada aos alunos com faixa de 15 anos em que se pressupõe o término da escolaridade básica obrigatória na maioria dos países. O Brasil tem tido um desempenho um pouco melhor em sua quinta participação em 2012, cujo foco foi 
Matemática, em comparação a 2003 que teve o mesmo foco. No entanto, esse avanço não foi o suficiente para elevá-lo no ranking mundial, pois ainda ocupando o $58^{\circ}$, com 65 países participantes. Os alunos brasileiros ainda apresentam muita dificuldade em aplicar o conhecimento em situações do cotidiano, e na explicação científica de eventos rotineiros.

Quadro 1: Comparativo dos resultados do Brasil no PISA desde 2000, segundo o INEP

\begin{tabular}{|c|c|c|c|c|c|}
\hline & 2000 & 2003 & 2006 & 2009 & 2012 \\
\hline Número de alunos participantes & 4.893 & 4.452 & 9.295 & 20.127 & 18.589 \\
\hline Leitura & 396 & 403 & 393 & 412 & 410 \\
\hline Matemática & 334 & 356 & 370 & 386 & 391 \\
\hline Ciências & 375 & 390 & 390 & 405 & 405 \\
\hline
\end{tabular}

Sobre essa questão da aplicação da matemática em situações contextualizadas, parece interessante valer-se do conceito, já clássico, da aprendizagem significativa (AUSUBEL, 1980, MOREIRA, 2006). A maior dificuldade está em entender do que se trata um aprendizado significativo, onde os alunos sejam capazes de compreender, se apropriar e aplicar o que lhes é ensinado em diferentes situações.

A prática em sala de aula nos mostra que os alunos são afetados de formas diferentes durante as aulas. Para os alunos que já gostam da disciplina e apresentam facilidade na mesma, a metodologia, os materiais didáticos, e a empatia com o professor e sua maneira de ministrar a aula talvez interfira pouco em seu aprendizado. Por outro lado, para os alunos que apresentam dificuldades, é preciso mais recursos para que se possa melhorar seu desempenho no estudo da Matemática, propiciando um melhor relacionamento com a mesma.

Podemos observar em nossa prática, e através das exigências do cotidiano escolar, que os alunos respondem as atividades que lhes são impostas, mas não conseguimos avaliar se essa resposta é decorrente de uma aprendizagem com real significado, ou apenas decorrente de uma memorização momentânea para realizar a atividade que lhe foi solicitada. No segundo caso, de fato, não houve compreensão e apropriação da ferramenta que lhe foi ensinada.

Assim, as funções da matemática e a presença da tecnologia nos permitem afirmar que aprender matemática deve ser mais do que memorizar resultados 
dessa ciência e que a aquisição do conhecimento matemático deve estar vinculada ao domínio de um saber fazer matemática e de um saber pensar matemático. (BRASIL, 1998, p. 252).

Segundo Muzzi (2004), não há um trabalho efetivo cujo foco seja uma perspectiva sócio-crítica de modelagem agregada a resolução de situações problemas. Nossa prática didática, em muitas vezes, fica limitada a fixação de conteúdos ou situações problemas distantes da realidade, não está sendo direcionada para a formação contínua de um cidadão crítico, através de um aprendizado significativo. Infelizmente, acabamos por contribuir para uma constante memorização ocasional e nada eficiente para formação do cidadão crítico.

(...) não é hora de buscarmos ressignificar a Matemática com a qual trabalhamos? (...) Não é hora de buscarmos uma Matemática que instrumentalize o cidadão para atuar e transformar a realidade em que vive? Uma Matemática crítica, que o ajude a refletir sobre as organizações e relações sociais? Uma Matemática próxima da vida, útil, compreensível, reflexiva? Uma Matemática que não se mostre perfeita, infalível, mas que seja capaz de ajudar a encontrar soluções viáveis? (MUZZI, 2004, p. 39).

Refletir sobre a própria prática e buscar uma transformação no ensino e aprendizagem para se proporcionar uma aprendizagem mais significativa na introdução do ensino de Álgebra é objeto da presente investigação. Para isso, começamos pela busca do conceito de aprendizagem significativa, que nos ajudará a justificar as escolhas que fizemos com relação às atividades propostas. 


\section{APRENDIZAGEM SIGNIFICATIVA}

O conceito de aprendizagem significativa é um clássico da educação, e se atribui a David Ausubel. Ele nasceu em 25 de outubro de 1918, em Nova Iorque - EUA, filho de uma família judia e pobre, imigrantes da Europa Central, cresceu muito insatisfeito com a educação, segundo ele próprio, "violenta e reacionária” que recebera. Em sua formação acadêmica, no Canadá, dedicou-se a educação, na busca por melhorias necessárias para um verdadeiro aprendizado, se preocupando também, com uma teoria que pudesse ajudar os professores em seu desempenho em sala de aula. Em sua teoria, o principal conceito é o de aprendizagem significativa.

Sua teoria sobre a aprendizagem significativa tem por elemento principal a construção de princípios que podem ser adaptados em diferentes contextos e situações, com diferentes pessoas.

Tem como ponto de partida o conjunto de conhecimentos que o aluno traz consigo, denominado por estrutura cognitiva. Definida por ele em 1968 e aprofundada por Ausubel, Novak e Hanesian em 1980, a aprendizagem que acontece quando as novas ideias se conectam a informações ou conceitos já existentes na estrutura cognitiva do indivíduo se denomina de aprendizagem significativa.

Desta forma a aprendizagem significativa só acontecerá quando as novas informações se relacionarem e se incorporarem à estrutura cognitiva de uma forma não substantiva e arbitrária, ou seja, quando o aluno conseguir acessar e relacionar os assuntos aprendidos em diferentes contextos.

Assim, a aprendizagem significativa caracteriza-se pela relação e diálogo entre a nova informação e algum aspecto relevante da estrutura cognitiva do sujeito. Essa informação só é aprendida de forma significativa, quando se relaciona e dialoga com outras ideias, conceitos ou proposições, que sejam relevantes e inclusivas, que estejam bem esclarecidas e disponíveis na mente do indivíduo e possam funcionar como âncoras para o novo conhecimento adquirido.

De acordo com as ideias de Azevedo (2001), podemos dizer, metaforicamente, que a estrutura cognitiva do aluno é como uma rede de saberes sempre inacabada e em constante construção, cheia de nós atados, soltos, desatados e pontas soltas, que oferecem a contínua possibilidade de serem ligadas a outras pontas, conectadas a novos fios, onde os nós poderão ser atados ou desatados, a partir das novas informações para que a rede seja ampliada. Dessa 
forma, os fios que já compõem a rede e se conectam a novos fios funcionam como ancoradouro e suporte para as novas partes da rede que serão costuradas, e bases para as novas aprendizagens que serão adquiridas.

Ainda nesta perspectiva, quando uma informação não é aprendida de forma significativa, e não há "fios" na rede cognitiva onde ela possa se conectar, ela é aprendida de forma mecânica. Ou seja, a informação recém aprendida não dialoga com as informações relevantes presentes na estrutura cognitiva do indivíduo, e por isso são armazenadas de forma arbitrária e literal. Dizemos então que houve uma aprendizagem mecânica.

Para Ausubel, Novak e Hanesian (1980) a aprendizagem mecânica e a aprendizagem significativa não se contrapõem, elas representam um continuun. Isso significa, segundo os autores, que em algum momento quando o aluno aprender conceitos inteiramente novos, a aprendizagem mecânica acontecerá inevitavelmente, pois não haverão "conceitos âncoras". Entretanto, com o tempo e a aquisição desses "conceitos âncoras" o aprendizado, que inicialmente era apenas mecânico, tornar-se-à um aprendizado significativo.

Para que esse continuun aconteça de forma mais acelerada, Ausubel (1980) nos sugere uma modificação na estrutura cognitiva do aluno através de organizadores prévios. Esses organizadores consistem em atividades prévias, nas quais são trabalhados conceitos e princípios que tenham maior poder de extensão e que possam ser utilizados como subsunçorespara a nova aprendizagem. Na teoria de Ausubel, subsunçor é uma ideia âncora, isto é, o conhecimento relevante especificamente para nova aprendizagem. Um subsunçor é, por exemplo, um símbolo já significativo, um conceito, uma proposição, um modelo mental, uma imagem.

Além disso, se faz necessário que esses conceitos sejam apresentados de forma programática, utilizando métodos que apresentem e ordenem a sequência dos conteúdos de forma a aumentar a clareza e a estabilidade da estrutura cognitiva.

Ausubel, Novak e Hanesian (1980), ainda destacam quatro vantagens da aprendizagem significativa em relação à mecânica: os conhecimentos que são aprendidos de forma significativa ficam retidos por maior tempo; as novas informações ajudam os alunos a diferenciarem as ideias âncoras, aumentando assim a capacidade de uma maior facilidade em aprender novos conceitos relacionados; mesmo que as informações sejam esquecidas após a assimilação, elas deixam resíduos em todo o quadro de conceitos relacionados; e por fim, as informações aprendidas significativamente podem ser aplicadas em diferentes e novos contextos e situações problemas. 
A aprendizagem significativa provoca transformações na estrutura do conhecimento do aluno. Essa transformação trata-se menos como "mudança conceitual", e mais como desenvolvimento, enriquecimento conceitual por meio da construção e discriminação de significados, o que pressupõe a aprendizagem significativa como geradora de modificação da estrutura cognitiva, sem eliminação, esquecimento dos conceitos anteriores a tal experiência ou simples adição (MOREIRA, 2005, p. 33)

Estas vantagens tornarão a ação do educador eficaz, e não apenas eficiente. Pois haverá por parte do educador a preocupação de oferecer aos alunos novos conceitos, métodos planejados para a construção de sentidos na sua aprendizagem. Adicionalmente, poderá oferecer aos alunos a oportunidade de se apropriar, de fato, do que lhe é ensinado e até mesmo ressignificar esses novos conceitos.

\section{TIPOS DE APRENDIZAGEM}

Na teoria apresentada por Ausubel, Novak e Hanesian (1980), há dois tipos básicos de aprendizagem, a aprendizagem por recepção e aprendizagem por descoberta, e ambas podem ser mecânicas ou significativas.

A aprendizagem por recepção, mecânica ou significativa, segundo os autores, realizase quando:

...todo conteúdo daquilo que vai ser aprendido é apresentado ao aluno sob a forma final. A tarefa de aprendizagem não envolve qualquer descoberta independente por parte do estudante. Do aluno exige-se somente internalizar ou incorporar o material (uma lista de sílabas sem sentido ou adjetivos emparelhados; um poema ou um teorema geométrico) que é apresentado de forma a tornar-se acessível ou reproduzível em alguma ocasião futura. (AUSUBEL; NOVAK; HANESIAN, 1980, p.20).

É comum percebermos esse tipo de aprendizagem no ensino de álgebra, quando lhes é ensinado manipulações algébricas, algoritmos de resolução de equações entre outros, como se fossem procedimentos naturais,como se sua utilização em suas vidas futuras fosse algo óbvio. Mais uma vez, recorremos a matematização de tudo, argumentando sua utilidade e presença em todas as coisas, sem mostrar de fato como isso acontece na prática. Ou ao menos, sem expor aos alunos a origem do conteúdo, como tais resultados foram obtidos e que 
determinados conceitos não são de fato utilizados em seu cotidiano, mas em situações específicas de algumas áreas do conhecimento.

Os alunos receberão a fórmula resolutiva da equação do $2^{\circ}$ grau, ou o fato de que nas

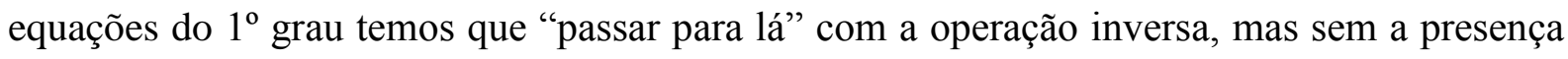
de conteúdos “âncoras”, essa aprendizagem recebida será mecânica. É o que tem acontecido na maioria das vezes, principalmente no ensino de álgebra, onde os conceitos são abstratos.

Para que haja uma aprendizagem por recepção significativa, segundo Ausubel, Novak e Hanesian (1980), “a tarefa ou matéria potencialmente significativa é compreendida ou tornada significativa durante o processo de internalização".

Segundo Tavares (2003), podemos ter uma situação de aprendizagem receptiva significativa, quando existirem condições do aluno transformar os significados lógicos de um determinado assunto potencialmente significativo, em significados psicológicos, em conhecimento construído e estruturado de modo idiossincrático.

$\mathrm{Na}$ aprendizagem por descoberta, sua principal característica é a descoberta resultante da ação do aluno, ele próprio construindo seu conhecimento. O aluno não receberá apenas os conceitos, mas a ele será proporcionado a descoberta advinda de suas ações, facilitando com que as observações e conclusões sejam incorporadas à sua estrutura cognitiva. Nesse caso, sua utilização favorece uma aprendizagem significativa, mas não garante que ela aconteça. Além do que, exige mais tempo e organização do educador para a realização de atividades desse tipo, que propiciem a descoberta e construção do conhecimento.

O conhecimento humano é construído; a aprendizagem significativa subjaz essa construção. (J.D. Novak)

O aluno deve reagrupar informações, integrá-las à estrutura cognitiva existente e reorganizar e transformar a combinação integrada, de tal forma que dê origem ao produto final desejado ou à descoberta de uma relação perdida entre meios e fins. Concluída a aprendizagem por descoberta, o conteúdo descoberto torna-se significativo da mesma forma que o conteúdo apresentado torna-se significativo na aprendizagem por recepção. (AUSUBEL, NOVAK e HANESIAN, 1980, p. 21)

Igualmente devemos levar em consideração outros elementos para que haja uma aprendizagem significativa. $\mathrm{O}$ aluno precisa apresentar uma predisposição para fazer as 
relações entre o novo conhecimento e as informações subçunsoras existentes em sua estrutura cognitiva. Segundo Novak (1998), a predisposição para a aprendizagem é uma das condições para que haja a aprendizagem significativa e está diretamente relacionada com a integração de pensamentos, sentimentos e ações, e dá a aprendizagem significativa uma conotação humana.

Essa integração entre pensamentos, ações e sentimentos traz pontos positivos e negativos. Segundo Novak, quando há a aprendizagem significativa, o aluno se sente bem, cresce e se predispõe a novas situações de aprendizagem. Quando isso não acontece, o aluno passa a desenvolver atitudes de recusa e não se submete a novas situações de aprendizado. $\mathrm{Na}$ perspectiva de Novak, a aprendizagem, o ensino, o currículo, o meio social e a avaliação também devem ser considerados para a busca de uma aprendizagem significativa. Ou seja, outras variáveis devem ser levadas em consideração na escolha de métodos e conceitos que buscam um aprendizado significativo.

A atitude do aluno é de crucial importância para o processo de aprendizagem significativa. O aluno deve manifestar um esforço e disposição para relacionar de maneira não arbitraria o novo material potencialmente significativo à sua estrutura cognitiva. Significando que não importa o quanto o material seja potencialmente significativo, se o aluno apenas tiver interesse de "decorar" a nova informação, não haverá a aprendizagem significativa do material. (TAVARES, 2005).

De acordo com Asubel, Novak e Hanesian (1980), os alunos acabam se predispondo a uma aprendizagem mecânica diante de um conteúdo significativo, por obterem respostas "prontas e corretas", deixando-os mais seguros diante das situações de aprendizagem. Nas palavras dos autores:

Uma outra razão é que, devido ao alto nível de ansiedade ou devido a uma experiência crônica de fracasso numa determinada disciplina (refletindo, por sua vez, uma baixa aptidão ou um ensino inadequado) isso acarreta uma falta de confiança em sua capacidade de aprender significativamente e, portanto, o aluno não vê outra alternativa senão a aprendizagem automática para torná-lo mais seguro. (Esse fenômeno é muito familiar aos professores de matemática, pois frequentemente se defrontam com o "estado de perplexidade" ou de "ansiedade de seus alunos") (AUSUBEL; NOVAK; HANESIAN, 1980, p.36). 
Para que não haja essa predisposição para uma aprendizagem mecânica (sem a possibilidade de tornar-se uma aprendizagem significativa), é necessário que haja atitude, tanto dos alunos quanto dos docentes em suas práticas. Muitas são as definiçõos e interpretações da palavra atitude, todas elas apresentam como senso comum à possibilidade de ser algo que influencie o comportamento.

Para Klausmeier e Goodwin (1977, p.414), o conceito de atitude também possui alguns atributos definidores como: aprendibilidade (sem consciência ou com intencionalidade); estabilidade (temporária ou permanente); significado (baixo ou alto); conteúdo (afetivo alto ou cognitivo alto); e orientação (com aproximação alta ou esquiva alta).

Brito (1996, p.11), define atitude como: "Uma disposição pessoal, idiossincrática, presente em todos os indivíduos, dirigida a objetos, eventos ou pessoas, que assume diferente direção e intensidade de acordo com as experiências do indivíduo. Além disso, apresenta componentes do domínio afetivo, cognitivo e motor”.

Tendo como base a definição dada por Brito, o professor que almeja proporcionar condições para que haja uma aprendizagem significativa, deve levar a atitude em consideração, e mais do que isso, precisa assumir uma direção e intensidade diferente, tendo como foco o indivíduo e os elementos necessários para a educação do futuro. "Assim, o professor, por sua vez, deve conhecer bem a ciência que ensina, ter o aluno como foco principal para seu trabalho e contextualizar suas aulas à realidade do aluno de modo a incentivá-los a aprender”.( DA CONCEIÇÃO, 2017)

Segundo Morin (2011, p.19), a educação do futuro requer um esforço transdiciplinar, que seja capaz de reconectar a cultura científica e a cultura das humanidades. O conhecimento não deve ser apenas visto como um reflexo ou espelho da realidade, e sim como uma tradução, seguida de uma reconstrução da experiência que o indivíduo é submetido.

Nessa concepção, pensar numa aprendizagem significativa na atualidade requer pensar nos conteúdos específicos do ensino e o material utilizado, mas que também tenha uma predisposição e atitudes positivas na busca da construção de um conhecimento complexo,ou seja, que seja construído junto com outros professores.

De acordo com Severino( 2003), "É que, dadas as nossas condições e a complexidade da prática, precisamos de múltiplos enfoques mediatizados pelas abordagens das várias ciências particulares; mas não se trata apenas de uma justaposição de múltiplos saberes: é preciso chegar à unidade na qual o todo se reconstitui como uma síntese que, nessa unidade, é maior do que a soma das partes. Por isso, precisa ser também prática transdisciplinar." 
A educação deve buscar as complexas relações entre o contexto, o saber e o indivíduo, para trazer novas perspectivas para olhar o mundo. Entretanto, em conjunto com todas as áreas do conhecimento, fragmentadas pelas disciplinas, mas unidas nessa busca por revelar novas articulações do saber. Articulações essas que serão capazes de questionar constantemente os conhecimentos e ressignificar os mesmos.

Professores com atitudes positivas em relação à Matemática, e que consigam enxergar a disciplina como parte de um todo, auxiliam no combate aos mecanismos predispostos a uma aprendizagem mecânica desenvolvida pelo aluno por conta da insegurança e da ansiedade. Atitudes positivas dão segurança e ajudam o aluno a ter independência e suas próprias atitudes no que diz respeito a estudar.

Para que o material escolhido seja compreendido e não memorizado, para que se torne um material potencialmente significativo, segundo Ausubel, faz-se necessário uma organização conceitual, para que haja uma conexão lógica com as ideias âncoras existentes na estrutura cognitiva do aluno e deve apresentar relação com as ideias especificamente relevantes.

Para tal, o professor deve buscar métodos que possam conhecer os conhecimentos prévios (construções pessoais) dos alunos e avaliar como relacioná-los aos conhecimentos que serão abordados em suas aulas. Afinal, segundo Ausubel, Novak e Hanesian (1980), o aprendizado só será significativo se os novos conceitos abordados se conectarem a estrutura cognitiva existente em cada aluno, e se tornar uma ancoragem para novos conceitos que surgirem. Desta forma, ao reorganizar o conhecimento do aluno ou identificar semelhanças e diferenças entre o que já sabia e o novo conteúdo aprendido, o aluno deixa claro o seu protagonismo ativo no próprio processo de aprendizagem (Moreira, 2003)

\section{ORGANIZADORES PRÉVIOS, DIFERENCIAÇÃO PROGRESSIVA E A RECONCILIAÇÃO INTEGRADORA}

Os organizadores prévios, segundo Ausubel, Novak e Hanesian (1980), são instrumentos (textos, trechos de filmes, esquemas, desenhos, imagens, fotos, afirmações, citações, mapas conceituais, jogos, programas de computador, entre outros) que nos ajudam na integração de novos conhecimentos, quando esses não possuem ideias subçunsoras ou quando as ideias âncoras existentes em sua estrutura não estão claras e estáveis o suficiente para ancorarem o novo conhecimento. 
A função principal de um organizador prévio é funcionar como uma "ponte cognitiva" entre o conhecimento que o aluno já sabe e o que ele irá saber. Além do que, podem constituir importantes instrumentos de contextualização sócio-cultural, já que criam referentes ao conteúdo.

Por Ausubel, Novak e Hanesian (1980), as funções básicas de um organizador prévio são:

“1. Oferecer uma armação ideativa para a incorporação estável e retenção do material mais detalhado e diferenciado que se segue no texto a aprender ou na exposição a acompanhar;

2. Aumentar a discriminalidade entre este último material e ideias similares ou ostensivamente conflitantes na estrutura cognitiva;

3. Tornar evidentes as ideias que porventura já existam na estrutura cognitiva e que possam servir de esteio às novas aprendizagens, potencializando assim a capacidade de aprendizagem do sujeito."

A utilização de um organizador prévio, através de um material que permita a apresentação de conceitos gerais, que tenham maior poder de extensão para os alunos tem como objetivo obter uma diferenciação progressiva e uma reconciliação integradora.

Na diferenciação progressiva, há uma organização sequencial, primeiro com as ideias gerais e inclusivas da disciplina, e depois elas são progressivamente diferenciadas em termos de detalhes e especificidades.

Nas palavras de Ausubel (2003, p.166):

(1) é menos difícil para os seres humanos apreenderem os aspectos diferenciados de um todo, anteriormente apreendido e mais inclusivo, do que formular o todo inclusivo a partir das partes diferenciadas anteriormente aprendidas;

(2) a organização que o indivíduo faz do conteúdo de uma determinada disciplina no próprio intelecto consiste numa estrutura hierárquica, onde as ideias mais inclusivas ocupam uma posição no vértice da estrutura e subsumem, progressivamente, as proposições, conceitos e dados factuais menos inclusivos e mais diferenciados." 
Segundo Moreira (1982, p.42), “a reconciliação integradora é um processo que acontece concomitantemente com a diferenciação progressiva". Esse processo consiste em integrar significados, relacionando ideias, proposições e conceitos, aponta as similaridades e as diferenças significantes e resolve as inconsistências.

Para Ausubel, o conhecimento prévio é o elemento mais importante a ser considerado quando se almeja uma aprendizagem significativa, “... o fator mais importante influenciando a aprendizagem é aquilo que o aluno já sabe; determine isso e ensine-o de acordo".

Dentre os organizadores prévios podemos destacar dois organizadores que abordam os principais aspectos relacionados à aprendizagem escolar: o organizador expositivo, referente à aprendizagem que decorre da tradicional relação e mediação (através da linguagem) entre professor e aluno; e o organizador comparativo, que é a aprendizagem através da comparação.

Os organizadores expositivos são propostos por Ausubel, Novak e Hanesian (1980), quando o novo conteúdo a ser abordado trata-se de um assunto totalmente desconhecido para os alunos. Assim o professor oferecerá ao aluno uma visão mais ampla do assunto, antes do detalhamento de suas especificidades.

No caso de organizadores comparativos, sua utilização pode ser eficiente, quando se tratam de conceitos conhecidos pelo aluno, para a integração de novos conceitos similares aos presentes na estrutura cognitiva do aluno. Esse organizador prévio tem como objetivo ressaltar as diferenças e semelhanças entre o que ele já sabe e o que será aprendido.

É importante ressaltar que organizadores prévios não são simples comparações introdutórias. Os organizadores prévios têm como objetivo, :

$1^{\circ}$ identificar o conteúdo relevante na estrutura cognitiva e explicar a relevância desse conteúdo para a aprendizagem do novo material; $2^{\circ}$ dar uma visão geral do material em um nível mais alto de abstração, salientando as relações importantes; $3^{\circ}$ prover elementos organizacionais inclusivos que levem em consideração, de modo mais eficiente, deixando em melhor destaque o conteúdo específico do novo material, ou seja, proporcionando um contexto ideal que possa ser usado para assimilar significativamente novos conhecimentos.(Moreira, 2014)

Como os organizadores prévios são tão importantes para um aprendizado significativo, é preciso que alguns cuidados sejam tomados, como garantir que esse organizador esteja em um nível compatível ao desenvolvimento da turma que irá ser trabalhado; que apresente uma maior extensão do assunto e seja instrumento de contextualização do assunto que será abordado; que o novo conceito abordado tenha relação 
com algo que ele tenha aprendido, ou algum assunto que esteja em voga nos meios de comunicação; e por fim, que sua apresentação seja clara e mais organizada possível.

No próximo capítulo então, faremos um estudo sobre a utilização da História da Matemática no ensino da Matemática, pois a História é um importante instrumento de contextualização, que nos ajuda a estabelecer relações e diálogos com outras disciplinas. No entanto, essa utilização não deve ser feita ao acaso. É preciso que se tome muito cuidado para que de fato esse instrumento venha trazer valor positivo aos alunos, e não se torne mais um "problema" a ser estudado. Então, como a História é um recurso que utilizaremos como organizador prévio através do cinema, vamos analisar algumas perspectivas da utilização da História da Matemática no ensino da Matemática. 


\section{HISTÓRIA NA EDUCAÇÃO MATEMÁTICA}

Muitas são as tendências estudadas e adotadas para o ensino da Matemática, e uma delas é a utilização da história na educação matemática, concebida como ação pedagógica e/ou como prática de investigação acadêmica.

A História da Matemática ajuda a proporcionar uma reconciliação integradora, na perspectiva de Ausubel, Hanesian e Novak, pois é um importante instrumento de contextualização sócio-cultural e permite um viés transdiciplinar que trabalha com o que está entre, através e além de todas as disciplinas.

A Matemática trará, através da história, uma nova perspectiva desse mundo novo, onde o pensamento científico, raiz de todas as teorias, trabalhará em prol da busca por um novo conhecimento incompleto e incerto, porque é histórico e se faz com o desenvolvimento da humanidade. Segundo Morin (2011, p. 73), é necessário mostrar em todos os domínios sobretudo na história o surgimento do inesperado. "É preciso aprender a enfrentar a incerteza, já que vivemos em uma época de mudanças, em que os valores são ambivalentes, em que tudo é ligado".

O professor que tem a intenção de fazer o uso consciente da História da Matemática deve pensar que tipo de vínculo quer estabelecer entre a produção sócio-histórica do conhecimento matemático no passado, e a sua produção e/ou apropriação no presente.

A seguir, apresentarei algumas perspectivas de ensino e suas respectivas intencionalidades com relação ao uso da História da Matemática.

\section{A HISTÓRIA DA MATEMÁTICA COMO UM ESPELHO}

As ideias da filosofia positivista apresentadas por Auguste Comte (1798 - 1857), em seus cursos na França do século XIX, foram trazidas para o Brasil por engenheiros e professores de Matemática das instituições militares brasileiras, ex-alunos de Comte, que divulgaram as ideias e adotaram seu modelo de racionalidade ao retornarem para o Brasil.

Essas ideias agradavam a nova burguesia durante o Império no Brasil, pois essas possibilitavam a conciliação entre ordem e progresso.

O positivismo tinha como fundamento principal, o pressuposto de que a sociedade humana era regulada por leis naturais, invariáveis e independentes da vontade e da ação 
humanas. Por isso, utiliza-se a mesma metodologia para o estudo das ciências naturais e das ciências sociais.

Segundo Motta (2006, p.25), Comte, através da sua "lei dos três estados", afirma que “o estado positivo só é alcançado quando o homem renuncia conhecer as causas e a natureza íntima das coisas e explica as relações entre as coisas e os acontecimentos pela formulação de leis", e reconhece uma igualdade de etapas, tanto no plano individual, como no plano da história da ciência.

Cria-se assim, uma visão internalista e indutivista da história da ciência e estabelece uma subordinação determinista do presente em relação ao passado: a História seria um espelho do que se passou, factual e ligada ao acontecimento em si. Motta (2006, p.25)

Torna-se perceptível a influência dessa visão com relação à história da matemática nas concepções de Piaget e Garcia e na ampliação realizada por Brousseau sobre a concepção de “obstáculo epistemológico" de Bachelard.

Para Piaget e Garcia (1982), a construção do conhecimento se dá da mesma maneira nos planos psicogenéticos (referentes à produção sócio-histórica do presente) e filogenéticos (referentes à produção sócio-histórica do passado), através dos mecanismos de transição.

Segundo Miguel e Miorim (2011, p. 88), “os objetos matemáticos são concebidos como complexos operatórios, ainda que a natureza de tais operações possa ser diferente dependendo do objeto considerado e a matemática é vista como uma reconstrução pessoal do conhecimento matemático já construído historicamente". Tanto a reconstrução histórica, quanto a reconstrução pessoal se desenvolveu de acordo com o mesmo esquema evolutivo. Segundo Redford (2000, p.146), os instrumentos de aquisição do conhecimento fazem parte da esfera biológica do indivíduo e não dependem do meio histórico ou cultural.

Nessa perspectiva, a história da matemática surge como um campo de possibilidades na busca de conflitos e de mecanismos operatórios referentes a determinado conceitos matemáticos que teriam surgido durante a passagem de uma a outra etapa do processo de construção desse conceito.

Segundo Miguel e Miorim (2001, p. 89), se não houver história da matemática que esteja dentro dessa perspectiva, torna-se necessário a construção de uma releitura

\footnotetext{
${ }^{1}$ Segundo Comte, cada ramo do conhecimento passaria sucessivamente em seu desenvolvimento por três estados históricos diferentes: o teológico, o metafísico e o positivo ou científico.
} 
epistemológica da mesma, com base nos pressupostos teóricos dessa perspectiva (objetivo central da pesquisa de Piaget e Garcia). Embora não defendam o argumento recapitulacionista, conseguimos observar essa característica pela maneira como defendem o uso da história da Matemática.

Com esse contexto, pressupomos que todos os alunos aprendem da mesma maneira, ao mesmo tempo, segundo um mesmo esquema evolutivo.

Desse modo ainda é mantido a mesma visão de evolução, os possíveis problemas, a hierarquia e a ideia de uma ciência pronta (como sugerida pelos positivistas), apenas reflexos do passado. A História da Matemática sendo utilizada como um espelho do passado.

\section{A HISTÓRIA DA MATEMÁTICA COMO PINTURA}

O abandono do princípio genético traz consigo o referencial vigotskiano e duas novas perspectivas, ainda em construção, sobre a utilização da História da Matemática na Educação Matemática: a perspectiva sócio-cultural e a perspectivas de jogos de vozes e ecos.

A perspectiva sócio-cultural está sendo desenvolvida e defendida por Luis Radford professor da Université Laurentienne do Canadá, e por Fulvia Furinghetti, professora da universidade de Genova, na Itália. Segundo Radford (1997, p.32) o papel da análise históricoepistemológica é conceber o conhecimento em geral, como " um processo cujo produto é obtido através de negociação de significados resultantes da atividade social dos indivíduos, no interior do contexto cultural que os envolve", e o conhecimento matemático em particular, como uma "manifestação simbólica de certas sensibilidades desenvolvidas pelos membros de uma cultura através de experiências compartilhadas e a partir das quais o significado dos produtos é produzido" (Radford, 1997, p.30).

Nesta perspectiva, de acordo com Radford, Guérette (1996, p.301-302), “a produção do conhecimento matemático, tanto na psico como na filogênese, é um PROCESSO DE NATUREZA SEMIÓTICA no qual os signos são concebidos como instrumentos psicológicos, simbolicamente constituídos e intimamente ligados às ATIVIDADES que os indivíduos realizam no interior do contexto cultural que os envolve".

Assim, a perspectiva sócio-cultural, cujo referencial teórico é neo-vygotskyano, a aprendizagem matemática é tida como a capacidade pessoal de internalizar (se apropriar, entender, utilizar e reproduzir), através de negociações interativas e dialógicas as significações sócio-históricas que formam os objetos matemáticos. Nesse caso há espaço para a etnomatemática, pois o processo de internalização se dá por atividades que são 
pedagogicamente adaptadas ao contexto escolar e é baseado em análises epistemológicas da história.

Nesse caso, a história da matemática torna-se um grande arcabouço de experiências humanas, que se constituem de situações, contextos e circunstâncias culturais que projetam o conhecimento matemático e suas transformações, e também, as significações intra e interculturais produzidas e negociadas durante a circulação, recepção e transformação desse conhecimento em diferentes situações e períodos.

A perspectiva de jogos de vozes e ecos, nome que lhe foi atribuído pela escola italiana de pesquisadores, os professores Paulo Boero, B. Pedemonte, E. Robotti e G. Chiappini possuem como referencial teórico os jogos de linguagem de Wittgenstein e o construto teórico vozes de Bakhtin. Possuem como núcleo firme a produção do conhecimento matemático, tanto na psico como na filogênese, como um processo de natureza semiótica, que inclui signos verbais e não verbais.

Nessa perspectiva, a matemática adquirida fora da escola, possui a mesma natureza dos conceitos que subsiste entre os conceitos científicos ou teóricos, práticos ou espontâneos. Desse modo, as experiências humanas necessitam de vozes originais que são produzidas em situações sociais legitimadas, a interpretam e se tornam modos compartilhados de se falar acerca da experiência humana. No entanto, o conhecimento que se constitui como gramática básica da cultura se reduz a um conjunto incoerente de ferramentas se não houver uma sistematização através de discurso teórico.

Esse processo de apropriação da cultura matemática, por parte do aluno, deve ser mediado por vozes da história da Matemática e das ciências, que são constantemente melhoradas em respostas a situações do presente. $\mathrm{O}$ aluno estabelece um diálogo imaginário, através do especo e do tempo, passado e presente, e cabe ao professor ser mediador dessas "vozes históricas".

Nesse caso, a utilização da história da matemática na educação matemática é vista como uma ferramenta ideal para se acessar características do conhecimento científico ou teórico que não são manifestados no conhecimento construído espontaneamente fora da escola. A história não tem o objetivo de construir ou validar nada, mas de ajudar os alunos a conjecturarem sobre os fatos, suas possíveis contradições, etc.

Em ambas as perspectivas mencionadas, a História da Matemática torna-se inspiradora de sequências didáticas para o ensino e a aprendizagem ao permitir a contextualização e possibilitar circunstâncias de produção dos conceitos, das significações produzidas e negociadas durante a elaboração do conceito, recepção e transformação desse conhecimento. 
Teríamos a História da Matemática como um ponto de partida para a criação de novos desenhos, novas pinturas, talvez uma exposição inteira.

Em todo caso, o professor exerce papel fundamental para a integração da História da Matemática na Educação Matemática. Seus valores que influenciam as suas concepções históricas; suas preocupações; fatores emocionais, sociais e culturais no processo de aprendizagem; sua formação histórica e matemática, inicial e continuada; e suas possibilidades de acesso a materiais, etc. Voltamos ao conceito de atitude, na busca de uma aprendizagem significativa.

De acordo com os Parâmetros Curriculares Nacionais,

O conhecimento da história dos conceitos matemáticos precisa fazer parte da formação dos professores para que tenham elementos que lhes permitam mostrar aos alunos a matemática como ciência que não trata de verdades eternas, infalíveis e imutáveis, mas como ciência dinâmica, sempre aberta à incorporação de novos conhecimentos (BRASIL, 1998, p.30)

Os PCN's reforçam o pensamento sobre o aspecto motivador da História da Matemática e propõem que: [...] ao revelar a matemática como uma criação humana, ao mostrar necessidades e preocupações de diferentes culturas, em diferentes momentos históricos, ao estabelecer comparações entre conceitos e processos matemáticos do passado e do presente, o professor tem a possibilidade de desenvolver atitudes e valores mais favoráveis do aluno diante do conhecimento matemático (BRASIL,1998, p. 42). 


\title{
III. CINEMA E HISTÓRIA DA MATEMÁTICA - NA BUSCA POR UM APRENDIZADO SIGNIFICATIVO
}

\author{
Eu creio na imagem... Na imagem todo-poderosa. \\ Que constrói o movimento. Cria o ritmo. Que revela a alma. \\ Vinícius de Moraes
}

O estudo da História da Matemática torna-se mais significativo quando está relacionado ao contexto mais amplo da História da Ciência e da História da Humanidade, de tal forma, que a Matemática possa ser vista como um produto sócio cultural.

A ciência e a cultura muitas vezes são retratadas em produções cinematográficas. $\mathrm{O}$ cinema tornou-se um instrumento eficaz de comunicação e difusor do conhecimento, fazendo com que novas ideias sejam divulgadas e constituindo valores culturais.

Nessa perspectiva sócio-cultural, há a necessidade de se buscar compreender o desenvolvimento da Matemática dentro de diferentes contextos sociais e culturais, e suas relações com o desenvolvimento de outras formas de conhecimento. Nas palavras de Souto (2013, p.21), “os filmes proporcionam outros modos de "ver" os fatos ocorridos ou imaginados, conduzindo-nos, muitas vezes, a situações e ambientes que não poderíamos sequer imaginar. O cinema fascina e inquieta". Segundo Ferro (2010, p. 31) "O filme, mesmo controlado, testemunha".

Os filmes, além de situar o contexto histórico da produção científica, em especial, da Matemática, pode ser um instrumento eficiente para um uso interdisciplinar da História da Matemática e para a sua inserção num projeto educativo mais amplo, e quiçá mais significativo.

A utilização de elementos históricos, que estão inseridos nos filmes e vídeos didáticos, podem contribuir para o ensino da Matemática, pois possibilitam um diálogo interativo entre o saber matemático e a sua construção histórica e tornam o ambiente propício para a investigação e uma nova perspectiva sob a Matemática como ciência viva, humana, em construção e que discute ideias.

Fazendo-se essa abordagem, têm-se uma oportunidade preciosa para se discutir os assuntos relacionados a antigas e novas percepções sobre história e verdades, e sobre os limites da ficção. Souto ( 2013, p.22).

O filme escolhido, "Jogo da Imitação", tem a $2^{a}$ Guerra Mundial como plano de fundo, onde as disputas se configuram no âmbito social, político, religioso e até mesmo nos planos 
individual. Para Souto (2013, p.15), “o devir das sociedades humanas pode ser explicado por meio das constantes lutas pela vida e pela morte; pelas disputas de poder; pelas intrigas e animosidades cultivadas pela intolerância e pelo desejo de se sobrepor aos demais; pelas disputas movidas pela ambição desmedida e pela resistência àqueles que negam ao outro a sua humanidade".

$\mathrm{Na}$ tentativa de estabelecer relações possíveis entre os temas em destaque e sua utilização no ensino da Matemática, esse trabalho tem o intuito de utilizar o cinema como um organizador prévio, abordando a Segunda Guerra Mundial que é um assunto mais amplo, para construir pontes entre o que o aluno sabe e o que virá a saber.

O enredo do filme torna-se um assunto subsunçor, onde irá introduzir e ancorar os conceitos que irão ser abordados dentro do contexto de criptografia, e a História da Matemática surgirá como fonte inspiradora para a introdução do ensino de Álgebra, ao permitir a contextualização desse conhecimento, visando a construção de significados mais amplos.

Neste caso, o cinema assume um papel de motivador para a Matemática, introdutor ou auxiliar no desenvolvimento do conteúdo e contextualiza para a abordagem da criptografia. Além disso, a utilização dos filmes, acrescida do crescente interesse dos jovens pelos mesmos, nos dá a oportunidade de ter um organizador prévio capaz de estabelecer vínculos com a nova geração de estudantes e amplia as possibilidades de um aprendizado significativo.

Segundo Côrtez, (2010, p.67): "[...] o professor deve aproximar-se das várias mídias, conhecê-las em suas características e modos de funcionamento, para ter assim, condições de inseri-las criticamente no fazer pedagógico.”. Para a autora (Côrtez, 2010, p.69) "[...] os conteúdos do ensino, em todas as áreas, não são apenas os conceitos e princípios científicos que as sustentam, mas também (e principalmente!) os valores que dão sentido à ação humana $[\ldots]^{\prime \prime}$.

Nas discussões atualmente em andamento sobre a BNCC (segunda versão - abril de 2016), lê-se que "Na Base Nacional Comum Curricular, a Matemática propõe objetivos básicos de aprendizagem, mas tem, também, o papel de encorajar os professores a propiciarem aos estudantes oportunidades para o desenvolvimento da autoconfiança, mediante sua participação ativa em experiências desafiadoras e atraentes. O ensino de Matemática visa a uma compreensão abrangente do mundo e das práticas sociais, qualificando a inserção no mundo do trabalho, que precisa ser sustentada pela capacidade de argumentação, segurança para lidar com problemas e desafios de origens diversas. Por isso, é fundamental que o ensino 
seja contextualizado e interdisciplinar, mas que, ao mesmo tempo, se persiga o desenvolvimento da capacidade de abstrair, de perceber o que pode ser generalizado para outros contextos, de usar a imaginação (p.132).

O filme trata de princípios básicos de criptografia e criptoanálise como campo de pesquisa da Matemática, onde são tratadas de técnicas de criptografia de substituição de letras(monoalfabético e polialfabético) e análise de frequência para decifrar as mensagens.

Além disso, é interessante levarmos em consideração alguns aspectos do contexto histórico do século XX que o filme nos traz, com temas abrangentes capazes de estabelecer conexões com diversas áreas do conhecimento para uma maior compreensão e inserção no mundo. Entre eles, destaco alguns aspectos como:

- No início do século XX, as atividades humanas passaram por mudanças significativas em suas estruturas. Na Matemática, essas mudanças decorreram de sua estrutura interna, a teoria dos conjuntos adentrou em muitos dos seus campos, principalmente no que diz respeito às investigações sobre os fundamentos da disciplina e de suas estruturas abstratas na álgebra, lógica e espaços gerais. Essa transformação fez com que a Matemática deixasse de ser a teoria das quantidades para ser a teoria das estruturas. E com isso, novos campos de pesquisa foram abertos em junção com a Física Matemática, a Biologia e a Engenharia.

- Para Eric Hobsbawn, um historiador egípcio, em seu livro "Era dos extremos - breve século XX” (1994, p.15-16), os acontecimentos do século XX podem ser divididos em três fases:

A primeira fase, como a era da catástrofe, ficou marcada por duas grandes guerras, por revoluções que tinham como alternativas mundiais o sistema político da antiga URSS (União das Repúblicas Socialistas Soviéticas) e os regimes fascistas, e pela crise econômica de 1929 com a quebra da bolsa de valores de Nova Iorque que teve impactos mundiais.

A segunda, classificada por era do ouro, referente às décadas de 50 e 60 , onde se foi possível observar profundas transformações sociais e um grande crescimento econômico, advindo da estabilização do capitalismo.

A terceira fase, denominada por Eric como a era do desmoronamento, relativo ao período de 1970 a 1991, foi uma época de incertezas e crises, em que se desintegraram as instituições que limitavam o barbarismo contemporâneo, abrindo as portas para um futuro problemático e cheio de incertezas.

- Durante esse período, as atividades matemáticas também sofreram as consequências da estabilidade gerada pelas crises econômicas e das longas guerras mundiais. A Matemática desenvolvida na Alemanha, Itália, Hungria e outros países, tiveram grandes perdas durante os 
regimes fascistas, devido à imigração de profissionais que foram perseguidos por motivos políticos ou raciais, o que favoreceu consideravelmente a produção matemática nos Estados Unidos. Porém, com o final da Segunda Guerra, as relações internacionais entre esses estudiosos da Matemática foram retomadas.

- Nesse período é que ficou em cena o matemático industrial, aquele que investiga assuntos de interesse da indústria ou do Estado. Também houve um aumento de institutos de pesquisa da área, que eram financiados por empresas privadas. Os principais estudos provinham das aplicações tecnológicas e dos fundamentos. Algumas áreas que surgiram no século XIX, tomaram consistência no século XX, como: a álgebra geral, cálculo de probabilidades, análise funcional, topologia, lógica e métodos numéricos - esses últimos relacionados ao avanço dos dispositivos de cálculo.

- Segundo Souto (2013, p.120), um traço marcante do século XX é o fato da Matemática ser diversificada e cada vez mais relacionada com todos os ramos da atividade humana e com todas as esferas da vida social, e isso se intensifica cada vez mais. Nas palavras da autora, "Enfim, a sociedade tecnológica do século XX parece confirmar a velha crença na Matemática como "rainha das ciências".

Tendo em vista o objetivo do trabalho, que é buscar uma proposta de ensino e aprendizagem mais significativa na introdução do ensino de Álgebra, na perspectiva de Ausubel, Novak e Hanesian, e tendo escolhido também o cinema e a História da Matemática como organizadores prévios e instrumentos para introduzirmos a Álgebra, se faz necessário uma seleção e estudo da parte da História da Matemática que será abordada. E por isso, escolhi em especial a História da Criptografia, assunto principal do filme escolhido. $\mathrm{O}$ próximo capítulo tratar-se-à então, de uma breve história da criptografia, com algumas cifras e suas regras de formação para maior compreensão das atividades que serão propostas. 


\section{BREVE INTRODUÇÃO DA HISTÓRIA DA CRIPTOGRAFIA}

Por milhares de anos, reis, rainhas e grandes comandantes de exércitos dependeram de comunicações eficientes para governar seus países e comandar seus exércitos. E todos estavam cientes das consequências, caso suas mensagens fossem interceptadas e caíssem em mãos erradas, revelando segredos preciosos a nações rivais ou divulgando informações vitais para as forças inimigas. Foi exatamente essa ameaça de interceptação pelo inimigo que motivou o desenvolvimento de códigos e cifras, técnicas para disfarçar uma mensagem de modo que só o destinatário possa ler seu conteúdo( CRUZ,2009).

$\mathrm{Na}$ busca por segurança das informações, as nações criaram departamentos para a elaboração de códigos, inventando e utilizando os melhores códigos possíveis. E isso teve um forte impacto no curso da história humana.

Atualmente a criptografia tem um maior impacto nas atividades civis, mas ainda continua sendo muito importante na atividade militar. Organizações como do Quartel General de Comunicações do Governo Britânico (GCHQ - Government Communications Headquarters) e a Agência Nacional de Segurança (NSA - National Security Agency) norteamericana, por exemplo, continuam a fazer pesquisas secretas em criptografia, (Singh, 2001) assim como nas mensagens enviadas através dos aplicativos de comunicação atuais, como o aplicativo whatsapp.

Alguns dos primeiros relatos sobre a escrita secreta datam de Heródoto, considerado "o pai da história", que relatou em As Histórias, no conflito entre a Grécia e a Pérsia, que aconteceu no século V a.C, foi a arte da escrita secreta que salvou a Grécia de ser conquistada pelo déspota Xerxes (Singh,2001).

Nesse caso, a mensagem recebida pelos gregos, que os avisava do grande ataque persa, veio ocultada numa tabuleta de madeira. Demarato (um exilado grego que morava na cidade persa de Susa, mas que ainda sentia alguma lealdade por sua terra natal), raspou a cera de um par de tabuletas de madeira, escreveu embaixo o que Xerxes pretendia fazer, depois a mensagem foi coberta novamente com cera. Deste modo, as tabuletas pareciam estar em branco e não causariam problemas com os guardas ao longo da estrada.

Heródoto também narra outro caso, no qual se utilizou da ocultação da mensagem para garantir a transmissão segura da mesma. Nessa história Hestaeu queria encorajar Aristágora de Mileto a se revoltar contra o rei da persa, e para dar instruções de como ele deveria fazer isso, Hestaeu raspou a cabeça do mensageiro, escreveu a mensagem no couro cabeludo e esperou que ele voltasse a crescer. Sendo assim, o mensageiro pôde viajar tranquilo, quando 
chegou ao seu destino, raspou a cabeça e revelou o conteúdo da mensagem ao seu destinatário.

Esse tipo de comunicação secreta, que é realizada através da ocultação da mensagem, é conhecida como esteganografia, nome derivado das palavras gregas steganos, que significa coberto, e graphein, que significa escrever. E desde então, muitas maneiras de esteganografia foram usadas no mundo.

Em paralelo com o desenvolvimento da esteganografia, também houve a evolução da criptografia, derivada da palavra grega kriptos, que significa "oculto". A criptografia não almeja ocultar a mensagem, seu objetivo é esconder o significado da mensagem. Essa é a grande vantagem da criptografia, se a mensagem for interceptada por alguém, ela é ilegível pelo mesmo, que não conhecerá a "regra” para a sua escrita( SINGH,2001).

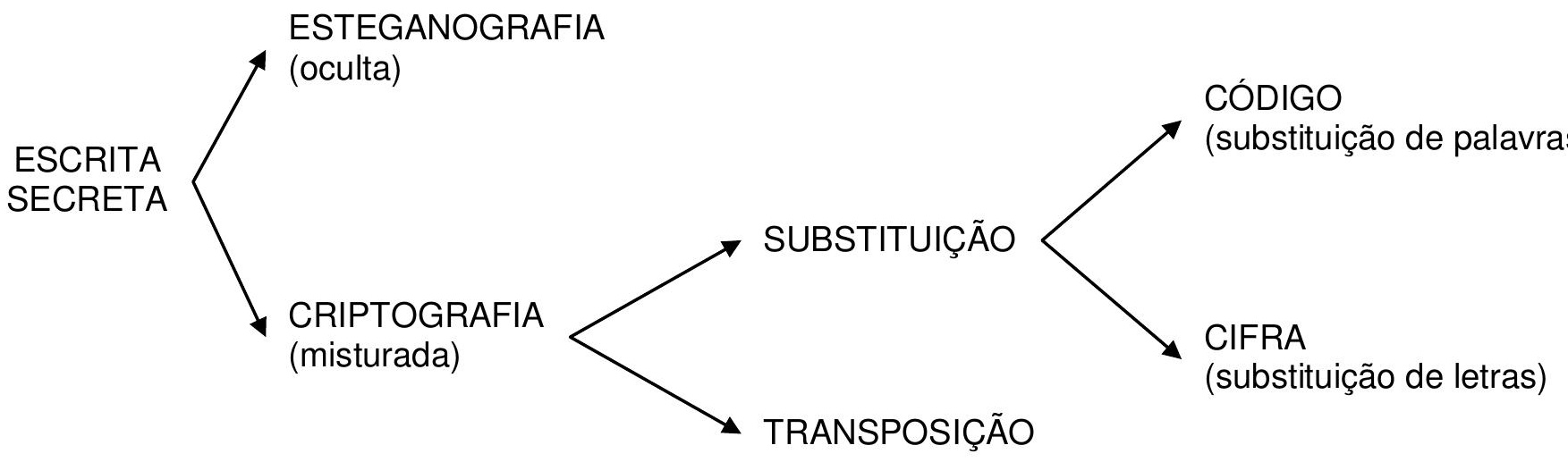

Figura 1: a ciência da escrita e suas principais ramificações (SINGH, 2001, p. 47).

Mesmo que a esteganografia e a criptografia sejam ciências independentes, ao misturálas, podemos ampliar o nível de segurança da mensagem. Um exemplo disso é o microponto, uma forma de esteganografia que se tornou popular durante a Segunda Guerra Mundial. Agentes alemães, que operaram na América Latina, reduziam fotograficamente uma página de texto até transformá-la num ponto com menos de um milímetro de diâmetro, e esse microponto era oculto sobre o ponto final de uma carta, aparentemente inofensiva. O primeiro microponto foi descoberto pela Agência Federal de Investigação norte americana (FBI Federal Bureau of Investigation), em 1941. A partir daí, os americanos puderam ler o conteúdo da maioria dos micropontos interceptados, exceto quando os alemães escreviam as mensagens em código. Sendo assim os agentes norte-americanos interceptavam as mensagens, mas nada conseguiam descobrir sobre os planos dos alemães.

A criptografia pode ser dividida em dois ramos: transposição e substituição (SINGH, 2001). Na transposição as letras são rearranjadas, formando um anagrama da palavra. No 
caso de mensagens muito curtas, de uma palavra, por exemplo, este método seria muito inseguro. Como no caso da palavra PATO, sabemos que há um número limitado e pequeno de maneiras. Exemplo: PATO - 24 anagramas: PATO, PAOT, POTA, POAT, PTOA, PTAO, APTO, APOT, ATPO, ATOP, AOTP, AOPT, TAPO, TAOP, TOPA, TOAP, TPAO, TPOA, OAPT, OATP, OPTA, OPAT, OTPA OTAP.

Já no caso de mensagens muito grandes, tornar-se- ia impossível obter-se a mensagem original, como no exemplo dado por Singh ( 2001, p. 23) "Como exemplo vamos considerar esta frase". Ela contém apenas 35 letras, e no entanto existem mais de 50000000000000 000000000000000000 de arranjos distintos. Se uma pessoa pudesse verificar uma disposição por segundo, e se todas as pessoas no mundo trabalhassem dia e noite, ainda assim levaria mais de mil vezes o tempo de existência do universo para checar todos os arranjos possíveis."

Ou seja, uma transposição ao acaso oferece um nível alto de segurança, mas uma mensagem pequena, como a do exemplo dado, pode tornar-se impossível, tanto para o destinatário quanto para o interceptador inimigo. Para que a transposição seja eficaz, é necessário que o rearranjo das letras seja de um modo direto e previamente combinado entre o transmissor e o destinatário.

Exemplo: Transposição da cerca de Ferrovia (Singh- 2001, p.24)

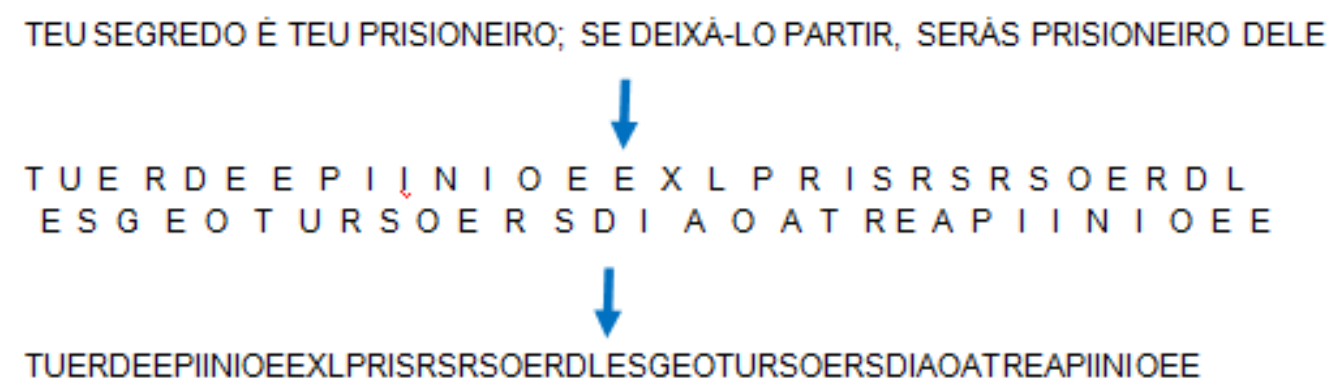

Outro exemplo de transposição é o citale espartano, que foi o primeiro aparelho criptográfico militar e data do século V a. C. (SINGH,2001). O citale é um bastão de madeira no qual é enrolado uma tira de couro ou pergaminho. O remetente escreve a mensagem no comprimento da citale e depois desenrola a tira, de modo que a tira parece conter uma série de letras sem sentido, pois a mensagem foi misturada. O mensageiro pode ainda, esconder a mensagem, utilizando a tira como um cinto. Para decodificar a mensagem, basta que o destinatário enrole a tira num bastão com o mesmo diâmetro que o bastão utilizado pelo remetente. 
Segundo Singh (2001, p.25),'No ano 404 a. C., Lisandro de Esparta recebeu um mensageiro ensanguentado e ferido, único sobrevivente de um grupo de cinco que partira da Pérsia numa árdua jornada. O mensageiro lhe entregou seu cinturão, que Lisandro enrolou em torno de seu citale para descobrir que o persa Farnabazo estava planejando atacá-lo. Graças ao citale, Lisandro estava preparado para o ataque e o repeliu".

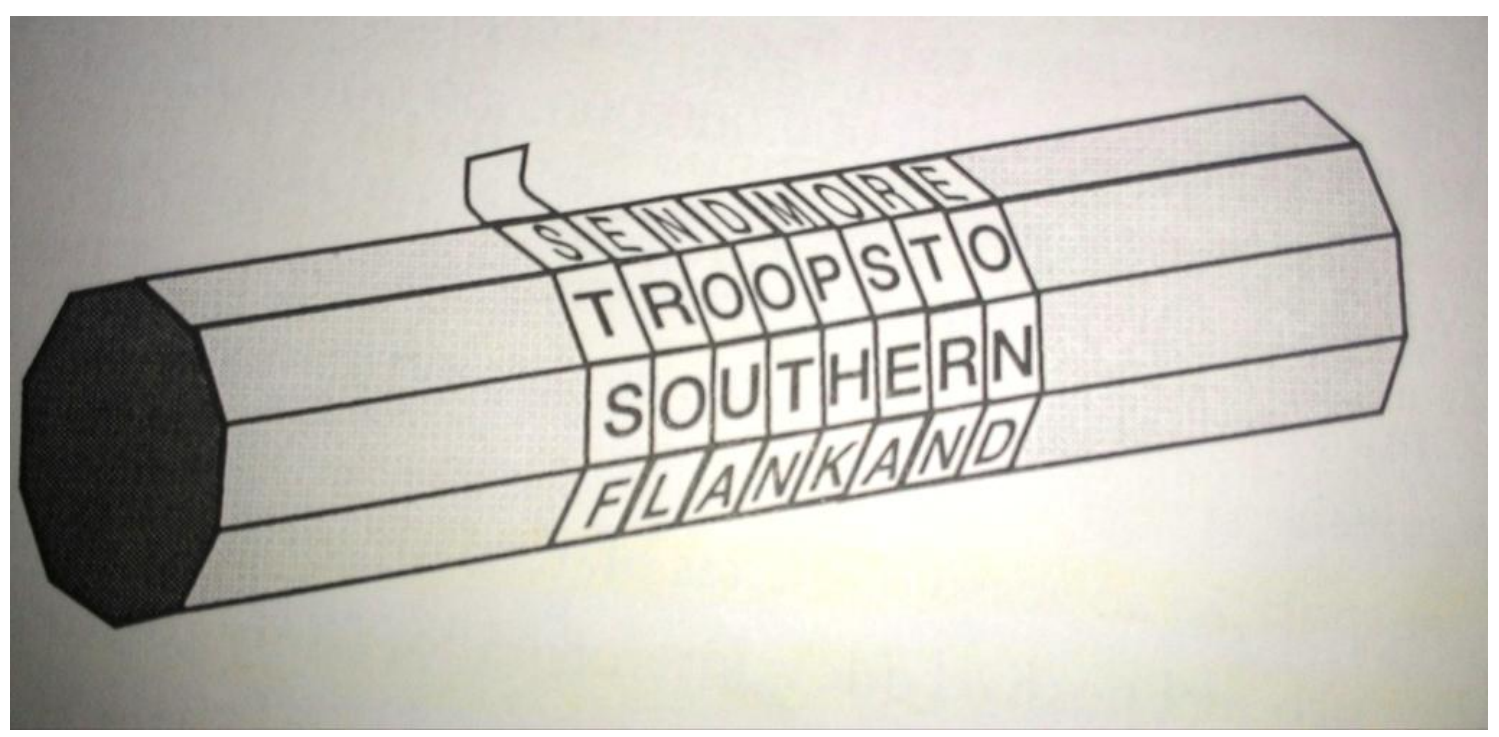

Figura 2: Citale Espartana ( Singh, 2001, p.24)

Já na substituição, as letras são substituídas por outras letras, números ou símbolos. O primeiro documento que utilizou uma cifra de substituição com objetivos militares aparece nas Guerras Gália de Júlio César. Nela César descreve como enviou uma mensagem para Cícero que estava prestes a se render, substituindo letras do alfabeto romano por letras gregas. Foi com As vidas de Césares, escrita por Suetônio, no século II que conseguimos obter uma descrição mais detalhada de uma das cifras de substituição utilizada por César, onde ele substituía cada letra por outra que estivesse três casas à frente no alfabeto.

\section{Exemplo:}

Texto Original: Vim, vi e venci.

Texto Cifrado: YLP, YL H YHQFL.

Sendo assim,

\section{Alfabeto Original}

\begin{tabular}{|l|l|l|l|l|l|l|l|l|l|l|l|l|l|l|l|l|l|l|l|l|l|l|l|l|l|}
\hline A & B & C & D & E & F & G & H & I & J & K & L & M & N & O & P & Q & R & S & T & U & V & W & X & Y & Z \\
\hline
\end{tabular}




\begin{tabular}{|l|l|l|l|l|l|l|l|l|l|l|l|l|l|l|l|l|l|l|l|l|l|l|l|l|l|}
\hline D & E & F & G & H & I & J & K & L & M & N & O & P & Q & R & S & T & U & V & W & X & Y & Z & A & B & C \\
\hline
\end{tabular}

Alfabeto Cifrado

Por volta de 204 a. C. a 122 a. C., o historiador Políbio descreveu em seu livro Histórias, um exemplo de código de substituição, que é atribuído aos seus contemporâneos Cleoxeno e Democleto.No código descrito por Políbio, cada letra é representada por um par de números compreendidos entre 1 e 5 , tendo por base a tabela $5 \times 5$.

\begin{tabular}{|c|c|c|c|c|c|}
\hline \multicolumn{1}{|c|}{} & 1 & 2 & 3 & 4 & 5 \\
\hline 1 & $\mathrm{~A}$ & $\mathrm{~B}$ & $\mathrm{C}$ & $\mathrm{D}$ & $\mathrm{E}$ \\
\hline \hline 2 & $\mathrm{~F}$ & $\mathrm{G}$ & $\mathrm{H}$ & $\mathrm{I}$ & $\mathrm{J}$ \\
\hline \hline 3 & $\mathrm{~K} / \mathrm{Q}$ & $\mathrm{L}$ & $\mathrm{M}$ & $\mathrm{N}$ & $\mathrm{O}$ \\
\hline \hline 4 & $\mathrm{P}$ & $\mathrm{R}$ & $\mathrm{S}$ & $\mathrm{T}$ & $\mathrm{U}$ \\
\hline \hline 5 & $\mathrm{~V}$ & $\mathrm{~W}$ & $\mathrm{X}$ & $\mathrm{Y}$ & $\mathrm{Z}$ \\
\hline
\end{tabular}

Exemplo:

Texto Original: Cifra de Políbio

Texto Cifrado: 1324214211141541353224122435

No código de Políbio há uma redução de caracteres utilizados (pois combinamos apenas os algarismos de 1 até 5) e também há a conversão de letras em números. Esse código serviu de base para outros códigos de cifragem, como a Cifra Playfair e a Cifra Campal Germânica (ADFGFX), usada na Primeira Guerra Mundial (SINGH, 2011).

Segundo Singh (2001, p.27), “ cada cifra pode ser considerada em termos de um método geral de codificação conhecido como algoritmo e uma chave, que especifica os detalhes exatos de uma codificação em particular. Neste caso, o algoritmo consiste em substituir cada letra do alfabeto original por uma letra do alfabeto cifrado, e o alfabeto cifrado pode consistir em qualquer rearranjo do alfabeto original. A chave define o alfabeto cifrado exato que será usado em uma codificação em particular". 


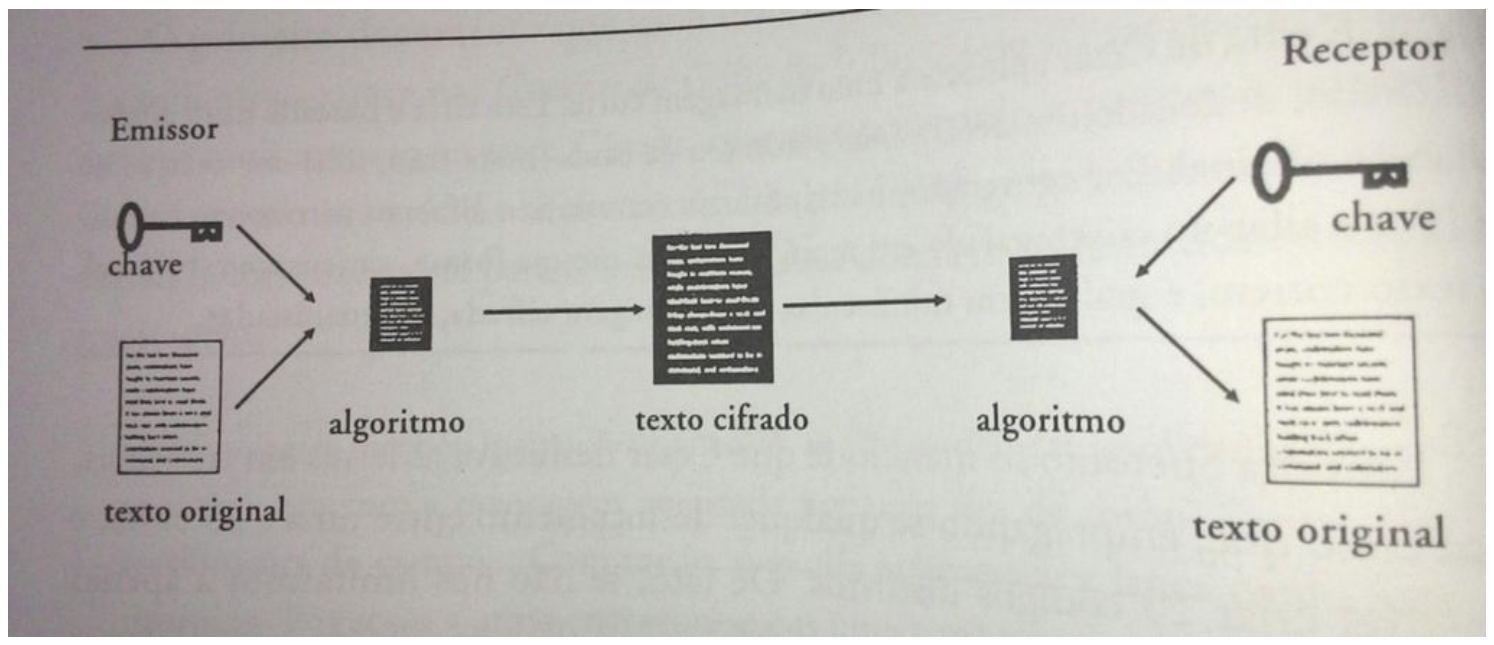

Figura 3: Apresentação da chave e do algoritmo a uma mensagem, segundo Singh (2001, p.28).

A segurança de um sistema de código está no fato de mantermos segura a chave do sistema. E mais, um sistema seguro deve ter um amplo conjunto de chaves em potencial. No caso da Cifra de César, temos um sistema fraco de segurança, pois existem apenas 25 chaves para cada letra, ou seja, uma mensagem uma vez interceptada, o inimigo terá que verificar apenas 25 possibilidades. Agora, num algoritmo para um sistema de substituição que possibilite que o alfabeto cifrado consista em qualquer rearranjo do alfabeto original, então existem 400000000000000000000000000 de chaves possíveis para serem verificadas, o que levaria muito tempo.

Durante muito tempo, a cifra de substituição monoalfabética simples, como a de César, foi suficiente para guardar os segredos. Mas o crescente desenvolvimento do estudo da análise da frequência, primeiro pelos árabes e depois pelos europeus, acabou com a sua segurança. Um exemplo disso foi a trágica morte de Maria, rainha da Escócia. Qualquer um que enviasse uma mensagem, estava sujeito a tê-la interceptada por um criptoanalista inimigo e ter seus segredos revelados. Tornou-se necessário que os criptógrafos criassem uma cifra mais forte, indecifrável.

No século XV, Leon Battista Alberti, pintor, compositor, poeta, autor da primeira análise de perspectiva científica e filósofo de destaque na Renascença. Ficou mais conhecido como arquiteto por projetar a primeira fonte de Trevi em Roma (e autor do primeiro livro de arquitetura - De Re Aedificatoria), por volta de 1640, escreveu um ensaio sobre os aspectos mais delicados da criptografia, traçando o que ele acreditava ser uma nova forma de cifra, mais segura.

Alberti propôs o uso de dois alfabetos cifrados, sendo utilizados alternadamente, de modo a confundir os criptoanalistas. 


\begin{tabular}{|l|c|c|c|c|c|c|c|c|c|c|c|c|c|c|c|c|c|c|c|c|c|c|c|c|c|c|}
\hline & A & B & C & D & E & F & G & H & I & J & K & L & M & N & O & P & Q & R & S & T & U & V & W & X & Y & Z \\
\hline Cifra1 & F & Z & B & V & K & I & X & A & Y & M & E & P & L & S & D & H & J & O & R & G & N & Q & C & U & T & W \\
\hline Cifra2 & G & O & X & B & F & W & T & H & Q & I & L & A & P & Z & J & D & E & S & V & Y & C & R & K & U & H & N \\
\hline
\end{tabular}

Exemplo:

Texto original: HELLO

Texto cifrado: AFPAD

Começando a cifra utilizando a cifra 1, em seguida a 2, voltando para a 1, e assim, sucessivamente, teremos duas letras distintas para representar a mesma letra L do alfabeto original. Aumentando assim o nível de dificuldade e a segurança da cifra de substituição.

Albieri avançou as cifras significativamente num período de mil anos, no entanto não conseguiu desenvolver sua ideia, transformando-a num sistema completo de cifragem. Esta missão coube a um grupo de intelectuais que aperfeiçoaram sua ideia original. Primeiro o alemão Johannes Trithemius, nascido em 1462, depois Giovanni Porta, um cientista italiano nascido em 1535, e por fim, um diplomata francês, nascido em 1523, Blaise de Vigenère(SINGH,2001).

Vigenère tomou conhecimento dos trabalhos de Albieri, Trithemius e Porta aos 26 anos, durante uma m issão diplomática em Roma, por 2 anos. No princípio, o interesse de Vigenère por criptografia era apenas profissional, por causa do trabalho. Somente aos 39 anos, quando ele tinha acumulado riqueza suficiente, o mesmo se "aposentou" e passou a dedicar a vida aos estudos. E então, pode examinar detalhadamente as ideias de seus precursores, misturando-as para formar uma nova cifra, coerente e poderosa, conhecida como Cifra de Vigenère(SINGH,2001). 
Cifra de Vigenère

\begin{tabular}{|c|c|c|c|c|c|c|c|c|c|c|c|c|c|c|c|c|c|c|c|c|c|c|c|c|c|c|c|}
\hline & & & 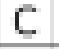 & & & & & & & & & & & & & & & & & & & & & & & & \\
\hline & & & $\mathrm{C}$ & $D$ & $E$ & & 6 & & | & & & & & & & & 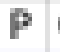 & & $\mathrm{P}$ & & $\mathbf{T}$ & & & & & & \\
\hline & & 8 & D & $E$ & $F$ & $\mathrm{G}$ & $\mathrm{H}$ & 1 & 1 & $\mathrm{~K}$ & $\mathrm{~L}$ & & & & & $P$ & $\mathrm{Q}$ & $\mathrm{A}$ & 5 & & $\mathbf{U}$ & $V$ & $W$ & $x$ & & & \\
\hline & & & $E$ & & $\mathrm{G}$ & $\mathrm{H}$ & $\|$ & & $\mathrm{K}$ & L & $\mathrm{M}$ & & & & & 0 & $\mathrm{R}$ & & 1 & & & $W$ & & $\mathrm{~T}$ & & & \\
\hline & & & $F$ & & $H$ & & 1 & 5 & L & & $\mathrm{H}$ & & & & & $\mathbf{R}$ & & $\mathrm{T}$ & $\mathrm{U}$ & & $W$ & $x$ & $Y$ & $\angle$ & & & \\
\hline & & & $G$ & I & I & ] & $\mathbf{K}$ & & $\mathrm{M}$ & $\mathbf{N}$ & 0 & & & & & 5 & $T$ & $\mathrm{U}$ & $V$ & $W$ & $\mathrm{X}$ & $\mathbf{Y}^{\prime}$ & 7 & A & & & \\
\hline & & G & $\mathrm{H}$ & & 」 & $\mathbf{K}$ & L & $M$ & 1 & & $P$ & & & & & $\mathrm{~T}$ & $\mathrm{U}$ & & $\mathrm{W}$ & $x$ & Y & $z$ & & B & & & \\
\hline & & $\mathrm{H}$ & | & 1 & $\mathbf{k}$ & $\mathrm{L}$ & $M$ & 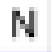 & 0 & $P$ & 0 & & & & & $\mathbf{U}$ & $v$ & $w$ & $x$ & $\mathrm{Y}$ & 2 & A & & $E$ & & & \\
\hline & $\mathrm{H}$ & $\mid$ & J & $\mathbf{K}$ & L & $\mathrm{H}$ & $\mathbb{N}$ & & $P$ & 9 & & & & & & $v$ & $w$ & $x$ & 1 & $z$ & & $B$ & & 0 & & & \\
\hline & & 1 & $\mathbf{K}$ & & $M$ & & 0 & & $\mathbf{Q}$ & & & & & & & $W$ & $\cdots$ & $\mathrm{T}$ & $z$ & 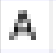 & & & & $t$ & & & \\
\hline 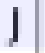 & ] & $\mathrm{K}$ & $\mathbf{L}$ & $\mathrm{M}$ & $\mathbb{N}$ & 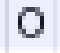 & $P$ & 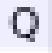 & 8 & & & & & & $N$ & $X$ & $\mathrm{Y}$ & $z$ & $A$ & B & & D & & 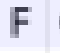 & $\mathrm{G}$ & & \\
\hline & K & L & $M$ & & 0 & & 0 & & 5 & & U & & & & 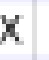 & $\mathrm{Y}$ & & 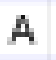 & B & 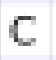 & & $\mathbf{E}$ & & & & & \\
\hline & 1 & $M$ & $\mathbf{N}$ & 0 & $P$ & 0 & $\mathbf{A}$ & & $T$ & 10 & W & & & 7 & ' & 7 & $\mathrm{~A}$ & B & $C$ & $D$ & $E$ & $F$ & & $\mathrm{H}$ & I & & \\
\hline 4 & $\|^{*}$ & $\mathrm{~N}$ & 0 & & 9 & & 5 & & U & $v$ & h & & & & & 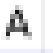 & B & C & $\mathbb{D}$ & $E$ & & 5 & & 1 & $J$ & $\mathbb{N}$ & \\
\hline & & 0 & $P$ & 9 & $\mathbf{R}$ & & $T$ & & 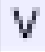 & $\omega$ & & & & & & & $\mathrm{C}$ & & $E$ & & 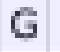 & $\mathrm{H}$ & & J & & & \\
\hline & & $P$ & $Q$ & 1 & 5 & 1 & $\mathbf{U}$ & $v$ & $W$ & $x$ & & & & & 3 & $\mathrm{C}$ & D & $E$ & $F$ & 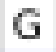 & $\mathbb{H}$ & I & & $\mathbf{K}$ & $\mathbf{L}$ & {$[1]$} & \\
\hline & & $\mathrm{Q}$ & $\mathrm{R}$ & & $\mathrm{T}$ & $\mathrm{U}$ & $\mathrm{v}$ & $N$ & $X$ & & & & & & & & $F$ & & $\mathbf{G}$ & & 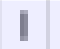 & J & & L & 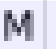 & & \\
\hline & 0 & $\mathrm{R}$ & 5 & $\mathrm{~T}$ & $\mathbf{U}$ & $Y$ & $\mathbf{W}$ & $x$ & $Y^{\prime}$ & $Z$ & & & & & & $\mathrm{t}$ & $F$ & $\mathrm{G}$ & $\mathrm{H}$ & I & 1 & $K$ & L & $\mathbf{M}$ & $\mathrm{N}$ & 0 & \\
\hline & $\mathrm{F}$ & 5 & $\mathrm{~T}$ & $\mathbf{U}$ & $\mathrm{V}$ & $\mathrm{N}$ & $x$ & & $z$ & $\mathbf{n}$ & & & & & & $\Gamma$ & $G$ & H & I & d & $\mathbf{K}$ & L & & N & 0 & & \\
\hline & 5 & $T$ & U & $\mathrm{v}$ & $W$ & $x$ & $\mathrm{Y}$ & & & & & & & & & & 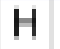 & I & 」 & & L & $M$ & 1 & 0 & $P$ & ) & \\
\hline . & T & U & $v$ & W & $x$ & I & 2 & & B & 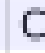 & & & & & 3 & $H$ & 1 & $\mathrm{~J}$ & $\mathbb{K}$ & L & $M$ & $\mathbf{N}$ & 4 & $P$ & 4 & $\mathbf{A}$ & \\
\hline & $\mathbf{U}$ & $V$ & $\mathbf{W}$ & $x$ & $\mathrm{Y}$ & $=$ & $A$ & & & & & & & & - & 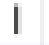 & 1 & $\mathbf{K}$ & $\mathrm{L}$ & 4 & t & 0 & $F$ & 0 & $\mathrm{R}$ & 5 & \\
\hline V & $\mathrm{V}$ & $W$ & $x$ & $\mathrm{Y}$ & 2 & $\mathrm{~A}$ & B & $C$ & D & $E$ & & & & & 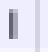 & J & K & L & $M$ & $\mathbb{N}$ & 0 & $\mathbf{P}$ & $\mathbf{Q}$ & $\mathrm{A}$ & $=$ & $\mathrm{T}$ & \\
\hline & $W$ & $X$ & $Y^{\prime}$ & $Z$ & $A$ & B & $\mathrm{C}$ & $\mathbf{L}$ & $E$ & 1 & & & & & & 1 & $\mathbf{L}$ & $\mathrm{M}$ & $\mathrm{N}$ & 0 & $\mathrm{P}$ & 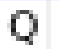 & $\mathrm{A}$ & 5 & 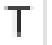 & L & \\
\hline & $x$ & $Y^{\prime}$ & $z$ & $A$ & B & $c$ & D & $\mathrm{E}$ & & 0 & & & & & K & L & $\mathbf{M}$ & & 0 & & 7 & $\mathrm{~A}$ & 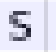 & $\mathrm{T}$ & & & \\
\hline & $\mathrm{Y}^{\prime}$ & $z$ & $\mathrm{~A}$ & B & C & 0 & $\mathrm{E}$ & 1 & 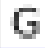 & $\mathrm{H}$ & & & & & & 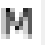 & $\mathbb{N}$ & 4 & $P$ & $y$ & $\mathbb{R}$ & 5 & $T$ & $\mathrm{U}$ & & 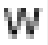 & \\
\hline & 7 & & B & 6 & $\mathrm{D}$ & $E$ & $F$ & & & & & & & & 4 & & 0 & $P$ & 9 & & & $T$ & & & & 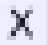 & \\
\hline
\end{tabular}

Figura 4: Tabela da cifra de Vigenère. Disponível em:

https://pt.wikipedia.org/wiki/Cifra_de_Vigen\%C3\%A8re\#/media/File:Vigen\%C3\%A8re_square_shading.svg. Acesso em 23 de Março de 2017.

Vigenère usa não apenas um, mas 26 alfabetos cifrados distintos para criar a mensagem cifrada.

Na primeira coluna da vertical, verificamos a letra da palavra chave, e na horizontal, a letra a qual desejamos cifrar.

Devemos escrever a palavra chave (que também poderá ser uma frase chave), repetidamente sobre a frase que deverá ser cifrada, até o final.

Exemplo:

Palavra- Chave: IME

Texto Original: História da Matemática 
Texto cifrado: PUWBAVQM HI YEBQQIFMKM

\begin{tabular}{|c|c|c|c|c|c|c|c|c|c|c|c|c|c|c|c|c|c|c|c|}
\hline I & M & E & I & M & E & I & M & E & I & M & E & I & M & E & I & M & E & I & M \\
\hline H & I & S & T & O & R & I & A & D & A & M & A & T & E & M & A & T & I & C & A \\
\hline P & U & W & B & A & V & Q & M & H & I & Y & E & B & Q & Q & I & F & M & K & M \\
\hline
\end{tabular}

Neste caso, procuraremos na linha do I (palavra chave), a letra que deveremos utilizar para cifrar a letra $\mathrm{H}$, e encontramos a letra $\mathrm{P}$. O mesmo acontecerá com a próxima letra, I. A letra da palavra chave que devemos procurar é na linha do M,e obtemos U, e assim, sucessivamente.

\begin{tabular}{|c|c|c|c|c|c|c|c|c|c|c|c|c|c|c|c|c|c|c|c|c|c|c|c|c|c|c|}
\hline & A & B & L & $D$ & L & & & & & & & L & & 10 & & & & & & & & & & & & \\
\hline & $\mathrm{A}$ & $\mathrm{B}$ & $\mathrm{C}$ & $D$ & $E$ & & 6 & & & J & $\mathbb{K}$ & $\mathrm{L}$ & M & $\mathbf{N}$ & 0 & $P$ & 9 & $\mathbb{R}$ & 5 & $\mathbf{T}$ & $\mathrm{U}$ & & $W$ & $x$ & & 2 \\
\hline B & $B$ & $\mathrm{C}$ & D & $E$ & $F$ & $G$ & $\mathrm{H}$ & & & $\mathrm{K}$ & $\mathrm{L}$ & $M$ & $\mathbf{N}$ & 0 & $P$ & $\mathbf{Q}$ & $\mathrm{R}$ & 5 & $\mathbf{T}$ & $\mathbf{U}$ & $V$ & $W$ & $X$ & $Y$ & 2 & A \\
\hline C & $\mathrm{C}$ & D & $\mathbb{E}$ & $F$ & $\mathrm{G}$ & $\mathrm{H}$ & I & & & $\mathrm{L}$ & $\mathbf{M}$ & $\mathbb{N}$ & 0 & $\mathbf{P}$ & $\mathrm{Q}$ & $\mathrm{A}$ & 5 & 1 & $\mathrm{U}$ & $y$ & $W$ & $x$ & $\mathrm{Y}^{\prime}$ & $z$ & A & B \\
\hline$D$ & D & $\mathbb{E}$ & $\mathbf{F}$ & 9 & $H$ & 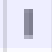 & 」 & $k$ & & $\mathbf{M}$ & $\mathrm{N}$ & 0 & $\mathrm{P}$ & 0 & $\mathbf{R}$ & 5 & $\mathrm{~T}$ & $\mathbf{U}$ & $\mathrm{V}$ & $\mathrm{W}$ & $x$ & $\mathrm{Y}$ & $z$ & A & B & $\mathrm{C}$ \\
\hline $\mathrm{E}$ & $E$ & $F$ & $\mathrm{G}$ & $\mathrm{H}$ & I & ] & $\mathbf{K}$ & & 11 & $\mathbf{N}$ & 0 & $\mathbf{P}$ & 9 & $\mathrm{~A}$ & 5 & $\mathrm{~T}$ & $\mathrm{U}$ & $\mathrm{V}$ & $\mathrm{W}$ & $X$ & $\mathbf{Y}$ & $z$ & $\mathrm{~A}$ & B & $\mathrm{C}$ & $D$ \\
\hline$F$ & $F$ & $G$ & $\mathrm{H}$ & I & 」 & $\mathbf{K}$ & L & & & 0 & $\mathrm{P}$ & Q & $R$ & 5 & $\mathrm{~T}$ & $\mathrm{U}$ & $\mathrm{V}$ & $W$ & $x$ & $\mathbf{Y}$ & $z$ & $\mathrm{~A}$ & B & C & $D$ & $\mathrm{E}$ \\
\hline $\mathrm{G}$ & $\mathrm{G}$ & $\mathrm{H}$ & 1 & $J$ & $\mathbf{K}$ & $\mathrm{L}$ & $M$ & & 4 & $\mathbf{P}$ & 9 & $\mathbb{R}$ & 5 & $\mathbf{T}$ & $\mathrm{U}$ & $y$ & W & $x$ & $\mathrm{Y}^{\prime}$ & 2 & $A$ & $\mathrm{~B}$ & $\mathrm{E}$ & D & $E$ & $F$ \\
\hline i & $\mathrm{H}$ & 1 & J & $\mathrm{K}$ & L & $\overline{\mathbf{F}}$ & $\mathrm{N}$ & & & 9 & $\mathrm{R}$ & 5 & $\mathbf{T}$ & $\mathbf{U}$ & V & $W$ & $x$ & $Y^{\prime}$ & $Z$ & A & B & $\mathrm{C}$ & D & $\mathrm{E}$ & $F$ & 0 \\
\hline & & & & & & & & & & $\mathrm{R}$ & 5 & $\mathrm{~T}$ & $\mathbf{U}$ & $y$ & $W$ & $x$ & $\mathrm{Y}^{\prime}$ & 2 & $\mathrm{~A}$ & B & $\mathrm{C}$ & D & $E$ & $\mathbf{F}$ & $\mathrm{G}$ & $\mathrm{H}$ \\
\hline I & \rfloor & $\mathrm{K}$ & L & $\mathbf{M}$ & $\mathbb{N}$ & 0 & $\mathrm{P}$ & $Q$ & & 5 & $\mathrm{~T}$ & $\mathbf{U}$ & $Y$ & $W$ & $X$ & $Y$ & $z$ & $A$ & B & $\mathrm{C}$ & $D$ & $\mathbf{E}$ & $F$ & $\mathrm{G}$ & $\mathrm{H}$ & | \\
\hline h & $\mathrm{K}$ & $\mathbf{L}$ & $\mathrm{M}$ & $\mathrm{N}$ & 0 & $\mathrm{P}$ & $Q$ & $\mathbf{R}$ & & $\mathrm{T}$ & $\mathrm{U}$ & $\mathrm{V}$ & $\mathrm{W}$ & $x$ & $Y$ & $\mathbf{Z}$ & $\mathrm{A}$ & $\mathrm{B}$ & $\mathrm{C}$ & D & $\mathbf{E}$ & $F$ & $G$ & $\mathrm{H}$ & I & \rfloor \\
\hline$\underline{L}$ & L & $M$ & $\mathbf{N}$ & 0 & $P$ & $Q$ & $\mathbf{R}$ & 5 & $\forall$ & U & $\mathrm{V}$ & W & $\mathrm{X}$ & $\mathrm{Y}$ & $z$ & $\mathrm{~A}$ & B & $\mathrm{C}$ & $D$ & $E$ & $F$ & $G$ & $\mathrm{H}$ & I & 」 & $\mathbf{K}$ \\
\hline$M$ & 4 & 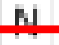 & 7 & 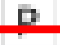 & & & 5 & & U & $v$ & $W$ & $x$ & $\mathbf{Y}$ & $z$ & $\mathrm{~A}$ & B & $\mathrm{C}$ & $\mathbf{D}$ & $\mathrm{E}$ & $\mathrm{F}$ & $\mathrm{G}$ & $\mathrm{H}$ & 1 & J & $\mathbb{K}$ & $\underline{\underline{L}}$ \\
\hline $\mathrm{N}$ & $\mathbb{N}$ & 0 & $P$ & 9 & $\mathbf{R}$ & 5 & $\mathbf{T}$ & $\mathrm{U}$ & $V$ & W & $x$ & $\mathrm{Y}^{\prime}$ & 2 & $\mathbf{A}$ & B & $\mathrm{C}$ & $\mathrm{D}$ & $E$ & $F$ & $G$ & $H$ & I & $J$ & $\mathbf{K}$ & $\mathrm{L}$ & $M$ \\
\hline 0 & 0 & $P$ & 0 & $\mathrm{R}$ & 5 & $\mathbf{T}$ & U & 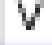 & $W$ & $x$ & $Y^{\prime}$ & 2 & A & $B$ & $C$ & D & $E$ & $F$ & $\mathrm{G}$ & $\mathbb{H}$ & I & $J$ & $\mathrm{~K}$ & $\mathbf{L}$ & $M$ & $\mathbb{N}$ \\
\hline 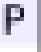 & $\mathrm{P}$ & Q & $\mathbf{R}$ & 5 & $\mathrm{~T}$ & $\mathbf{U}$ & $v^{\prime}$ & $M$ & $1 x$ & $Y^{\prime}$ & 2 & $A$ & $\mathrm{~B}$ & $\mathrm{C}$ & D & $E$ & $\mathbf{F}$ & $\mathrm{G}$ & $\mathrm{H}$ & I & J & $\mathrm{K}$ & $\mathbf{L}$ & $\mathbf{M}$ & $\mathrm{N}$ & 0 \\
\hline 9 & $Q$ & $\mathrm{R}$ & 5 & $\mathrm{~T}$ & $\mathbf{U}$ & $\mathrm{Y}$ & $\mathrm{W}$ & $X$ & $Y$ & 2 & $A$ & B & C & D & $\mathbb{E}$ & $\mathbf{F}$ & $\mathrm{G}$ & $\mathrm{H}$ & $\|$ & \rfloor & $\mathrm{K}$ & L & $\mathrm{M}$ & $\mathbf{N}$ & 0 & $\mathrm{P}$ \\
\hline i & $\mathrm{H}$ & 5 & $\mathbf{T}$ & $\mathbf{U}$ & $v$ & $\mathrm{~N}$ & $x$ & $Y$ & $z$ & $A$ & $\mathrm{~B}$ & C & $D$ & $E$ & $F$ & 5 & $\mathrm{H}$ & I & \rfloor & $\mathbf{K}$ & $\mathbf{L}$ & $\mathrm{M}$ & $\mathbf{N}$ & 0 & $P$ & 9 \\
\hline 5 & 3 & $\mathbf{T}$ & Џ & $\mathrm{V}$ & W & $x$ & $\mathrm{~T}$ & $z$ & $\mathrm{~A}$ & B & 5 & $D$ & $\underline{E}$ & $F$ & $G$ & $\mathrm{H}$ & I & 」 & $\mathbf{K}$ & $\underline{\underline{L}}$ & $M$ & $\mathbb{N}$ & 0 & $\mathbf{P}$ & $Q$ & $\mathbb{R}$ \\
\hline I & $T$ & $\mathrm{U}$ & $v$ & W & $x$ & $\mathbf{Y}$ & $z$ & $\mathrm{~A}$ & B & $\mathrm{C}$ & $D$ & $E$ & $F$ & 6 & $\mathrm{H}$ & 1 & J & $\mathbf{K}$ & L & H & $\mathbf{N}$ & 0 & $\mathbf{P}$ & 9 & $\mathrm{R}$ & 5 \\
\hline U & U & V & W & $x$ & $Y^{\prime}$ & $Z$ & $A$ & 8 & $\mathrm{C}$ & D & & $F$ & 6 & $\mathrm{H}$ & I & J & $\mathbf{K}$ & $\mathrm{L}$ & $\mathrm{M}$ & $\mathbf{N}$ & 0 & $\mathrm{P}$ & $\mathrm{Q}$ & $\mathrm{R}$ & 5 & $\mathbf{T}$ \\
\hline 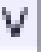 & $y$ & $W$ & $x$ & $\mathrm{Y}^{\prime}$ & $z$ & $\mathrm{~A}$ & B & $\mathrm{C}$ & D & $E$ & $F$ & $\mathrm{G}$ & $\mathbf{H}$ & I & J & $\mathbf{K}$ & L & $M$ & $\mathbb{N}$ & 0 & $\mathbf{P}$ & $\mathrm{Q}$ & $\mathrm{A}$ & 5 & $\mathrm{~T}$ & $\mathbf{U}$ \\
\hline 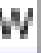 & $W$ & $x$ & $\mathrm{Y}$ & $z$ & $A$ & $\mathrm{~B}$ & $\mathrm{C}$ & 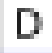 & $E$ & $F$ & 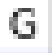 & $\mathrm{H}$ & 1 & J & $\mathbf{K}$ & L & $\mathbf{M}$ & $\mathrm{N}$ & 0 & $P$ & $\mathrm{Q}$ & $\mathrm{A}$ & 5 & $\mathrm{~T}$ & $\mathrm{U}$ & $\mathrm{v}$ \\
\hline$n$ & $X$ & $Y^{\prime}$ & $z$ & A & B & $\mathrm{C}$ & $D$ & $E$ & $F$ & $G$ & $\mathrm{H}$ & I & 」 & $K$ & $\mathrm{~L}$ & $\mathbf{M}$ & $\mathbf{N}$ & 0 & $P$ & $Q$ & $\mathbf{R}$ & 5 & $\mathrm{~T}$ & $\mathrm{U}$ & $\mathrm{V}$ & \\
\hline$t$ & T & $z$ & A & B & C & $D$ & E & 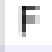 & $\mathrm{G}$ & H & 1 & 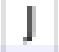 & $\mathbf{K}$ & $\mathbf{L}$ & $\mathbf{M}$ & $\mathbb{N}$ & 0 & $P$ & $\mathrm{Q}$ & $\mathbb{R}$ & 5 & $\mathrm{~T}$ & $\mathrm{U}$ & $V^{\prime}$ & W & $X$ \\
\hline 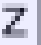 & $z$ & $\mathrm{~A}$ & B & $\mathrm{C}$ & 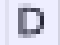 & 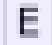 & 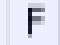 & & 1 & | & & K & ㄴ. & $M$ & $\mathbf{N}$ & 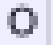 & $\mathbf{P}$ & 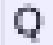 & 4 & & $\mathrm{~T}$ & & & & $x$ & \\
\hline
\end{tabular}

Os estudos de Vigenère resultou em seu Traicté dês Chiffres ( Um tratado sobre a Escrita Secreta), publicado em 1586, no mesmo ano em que Thomas Phelippes, quebrou a cifra de Maria, rainha da Escócia. E embora com um nível de segurança bem maior, a cifra de Vigenère recebeu pouca atenção e foi negligenciada nos dois séculos seguintes. 
Antes de Vigenère as cifras de substituição eram chamadas de monoalfabéticas, pois utilizavam apenas um alfabeto cifrado; já a cifra de Blaise ficou conhecida como polialfabética, pois empregava o uso de vários alfabetos cifrados por mensagem, o que tornou seu uso também mais complicado do que o usual e acabou desestimulando sua utilização para a maioria das pessoas.

Foi somente em 1863, que um criptólogo alemão chamado Kasiski descobriu como quebrar a cifra de Vigenère. O matemático inglês Charles Babbage já havia conseguido em 1854, mas não publicou a sua descoberta (singh,2001).

O final do século XIX foi um período confuso para a criptografia. Desde que Babbage e Kasiski acabaram com a segurança da cifra de Vigenère, havia a procura por uma cifra capaz de restabelecer as comunicações secretas, possibilitando aos homens de negócio e militares que explorassem a rapidez do telégrafo, sem ter suas mensagens decifradas. Além disso, na virada do século, o físico italiano Guglielmo Marconi inventou uma forma ainda mais potente de comunicação, aumentando assim a necessidade de uma codificação mais segura. Iniciou-se então, a mecanização do sigilo.

Damos um salto na história, e discutiremos o funcionamento da máquina Enigma através do filme: Jogo da Imitação. 


\section{METODOLOGIA}

\section{PLANEJAMENTO DA PESQUISA}

Os resultados pouco satisfatórios que o Brasil tem obtido no que diz respeito ao ensino da Matemática, em avaliações nacionais e internacionais; a falta de motivação dos alunos na sala de aula para aprender Matemática e a pseudo contextualização da disciplina; e as recentes discussões da Base Nacional Comum Curricular - BNCC (segunda versão - abril de 2016) me levaram e motivaram a estudar sobre a Teoria da Aprendizagem Significativa, refletir sobre o uso intencional da História da Matemática, em especial, a História da Criptografia para contextualizar e inspirar as sequências didáticas que irão introduzir o ensino de Álgebra no Ensino Fundamental II e buscar no cinema o organizador prévio capaz de estabelecer relações mais amplas de conhecimento e vínculos maiores com a nova geração. Para tal, surgiram os seguintes passos:

$1^{\circ}$ Passo: A Teoria da Aprendizagem significativa foi estudada dando foco em métodos para acelerar o processo da aprendizagem através de organizadores prévios. Assim como dando a importância ao uso intencional da História da Matemática, História da Humanidade e História da Criptografia através do cinema.

$2^{\circ}$ Passo: Com base nesses estudos, foi elaborada uma sequência didática que visasse uma aprendizagem potencialmente significativa no ensino introdutório da Álgebra, onde foi utilizado um filme como organizador prévio atuando como uma "ponte cognitiva" entre o que o aluno já sabe e o que ele irá saber.

$3^{\circ}$ Passo: Foi aplicada sequência didática de 8 atividades em 3 turmas do $8^{\circ}$ ano em uma escola particular de São Paulo.

$4^{\circ}$ Passo: Os resultados obtidos na aplicação da sequência didática foram analisados qualitativamente, de acordo com os referenciais teóricos adotados.

A utilização de organizadores prévios e do uso da criptografia (transposição e substituição) como facilitadores ao ensino da Álgebra em turmas do Ensino Fundamental II são adotadas por mim desde o inicio da década, tendo como principal objetivo facilitar o entendimento da escrita algébrica em minhas turmas do $8^{\circ}$ ano.

Esta prática foi fortalecida e inspirada pelas aulas de Álgebra com Aplicações do Professor Ph. D Francisco César Polcino Milies, já no programa de mestrado em 2013 e cuja sequência foi aprimorada e aplicada durante a minha pesquisa para a dissertação.

A aplicação desta sequência didática se deu no inicio de 2016 , no meu $4^{\circ}$ ano como professora de Matemática dos oitavos anos do Colégio São Domingos. 


\section{O COLÉGIO SÃO DOMINGOS (CSD)}

O CSD surgiu de uma articulação da sociedade civil em 1959, com a iniciativa de criar a Associação Cultural São Paulo, entidade jurídica que deu origem ao Colégio São Domingos.

Os moradores de Perdizes se mobilizaram com o objetivo de criar uma escola primária e secundária que fosse alternativa às demais escolas já existentes na região. Dentre os objetivos dos fundadores estavam a oferta de vagas para ambos os sexos, atualidade das concepções e práticas de ensino e que fosse uma instituição sem fins lucrativos e particularmente confiada às famílias.

A Ordem dos Frades Dominicanos e a Pontíficia Universidade Católica de São Paulo (PUC-SP) acolheram a iniciativa e contribuíram para a sua efetivação. Os acordos feitos pelos Dominicanos e pela reitoria da PUC-SP possibilitaram a aquisição do antigo casarão que havia sido residência de Alexandre Marcondes Machado Filho, político que foi ministro durante a era Vargas e presidente do senado federal.

As primeiras orientações pedagógicas vieram da produção acadêmico-científica da PUC-SP, cujo foco desde então está no ensino com foco na subjetividade dos alunos e na realidade social.

Ficou estabelecido o espírito democrático e a gestão participativa que inclui alunos, funcionários, professores, pais, direção e mantenedora no Conselho de escola, aumentando dessa maneira a participação e responsabilidade pela sustentação e melhorias da escola.

As práticas pedagógicas do Colégio São Domingos têm como objetivo a interação entre alunos, educadores e as fontes físicas ou digitais de informações e conhecimentos. Partimos da ideia que todos, crianças, jovens e adultos são portadores de saberes, particularidades e que possuem uma maneira própria de ler o mundo e levamos em consideração as concepções e argumentos preexistentes sobre os fenômenos em análise para, a partir deles, aprofundar, redimensionar, reparar as noções até então estabilizadas. Tornandose assim, a condição necessária para que os novos conhecimentos construídos coletivamente tenham significado para os nossos estudantes.

As ações educativas são orientadas para proporcionar a cada aluno, desde as séries iniciais, encontros com a heterogeneidade, de modo que aprendam o valor das diferenças na construção de si mesmos a no desempenho de papéis sociais. Esta é a postura que pauta as escolhas dos conteúdos a serem trabalhados em todos os ciclos escolares, as estratégias empregadas nos processos de aprendizagem e a convivência de todos os membros da comunidade escolar. 
No Projeto Político Pedagógico ${ }^{2}$ da escola foram eleitos alguns princípios que sintetizam sua proposta educacional:

- Produção coletiva de conhecimento e ações;

- Contextualização e problematização dos saberes;

- Ação investigativa para construir conhecimentos;

- Desenvolvimento da postura crítica e propositiva;

- Criatividade dos afazeres pedagógicos;

-Transparência dos objetivos propostos e dos processos vividos;

-Desenvolvimento da cooperação nas relações interpessoais;

- Afirmação da diversidade em sua plenitude;

- Exercício ético frente a tomadas de decisão;

- Diálogo para a solução de conflitos.

Sobre o processo de formação dos alunos:

Inclui o acesso reflexivo ao patrimônio cultural historicamente produzido, mas não restringe a ele. Há também um forte investimento para que novas articulações entre tais saberes sejam propostas e testadas.

Temos a compreensão de que além de proporcionar o contato com o conhecimento analítico, consagrado nos estudos disciplinares, temos a necessidade de formar indivíduos capazes de pensar sistemicamente, considerando os múltiplos aspectos que envolvem cada ação, cada tomada de decisão ou proposta de solução para as questões atuais.

Essa complexidade é acessível pela rearticulação dos conhecimentos das muitas áreas específicas. A forma mais eficaz de educar para essa dimensão é a prática da investigação a partir de problemas verdadeiros e de relevância para a vida social. A busca de propostas de equacionamentos desses problemas leva educadores e alunos a valer-se de informações de fontes heterogêneas, colocando em prática um verdadeiro enredamento de conhecimentos. (...)

\footnotetext{
${ }^{2}$ Disponível em http://www.sdomingos.com.br/site2015/proposta-pedagogica/proposta-principios e http://www.sdomingos.com.br/site2015/proposta-pedagogica/proposta-regimentoescolar, visualizado em Março/2017.
} 
Como resultado de muita discussão, estudo e análises da equipe gestora e equipe de coordenação, visando os propósitos já descritos acima, surgiu a seguinte representação que direciona e inspira nossas ações:

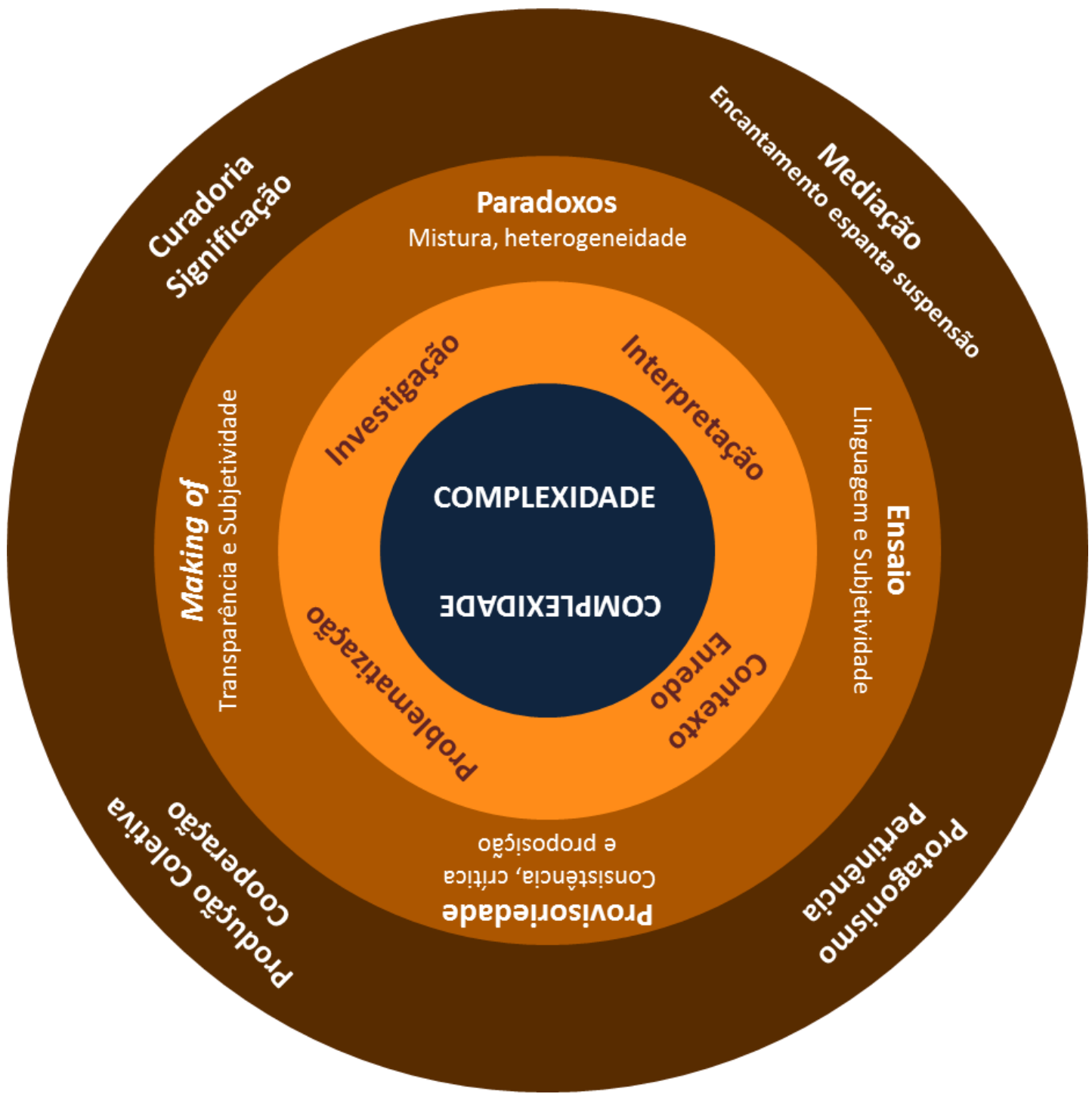

Nessa representação, temos no centro e que também é o ponto de partida a palavra complexidade. A palavra complexo vem do latim complexus, que quer dizer "aquilo que é tecido em conjunto".

[...] a complexidade é um tecido (complexus: o que é tecido junto) de constituintes heterogêneas inseparavelmente associadas: ela coloca o paradoxo do uno e do múltiplo. Num segundo momento, a complexidade é efetivamente o tecido de acontecimentos, ações, 
interações, retroações, determinações, acasos, que constituem nosso mundo fenomênico (Morin, 2005, p. 13).

Nessa perspectiva, e também inspirados pelo Pensamento Complexo de Edgar Morin, há uma ruptura com o padrão de pensamento cartesiano, que acaba fragmentando o conhecimento e muitas vezes negligencia as relações existentes entre esses conhecimentos e que são de suma importância para uma visão e compreensão significativa do todo.

Ao repensarmos a educação dessa maneira, abrimos mão dos paradigmas atuais e optamos por uma postura de cooperação, que valoriza e reestabelece as relações e as atitudes significativas. Pensar e partir do complexo muda a forma de conexão que estabelecemos com o conhecimento. Segundo Morin,(em entrevista para O Globo, 2017), "não se trata de rever doutrinas e métodos, mas elaborar uma nova concepção do próprio conhecimento".

O professor então assume um importante papel para a produção coletiva de conhecimentos e ações, na busca de uma aprendizagem mais significativa para o desenvolvimento do senso crítico dos alunos.

Nesse caso, o professor não tem apenas o papel de comunicador, visto que os alunos tem outras fontes de conhecimento, mas a experiência do conhecimento se constitui com os alunos.

Através de um contexto mais enredado, com a escolha de assuntos pertinentes a discussão e que possam ser discutidos e relacionados através das várias perspectivas das disciplinas, há a proposição de situações que possibilitam a problematização, a investigação e várias interpretações.

Em resumo, a complexidade - tema central da proposta pedagógica do Colégio São Domingos e ponto de partida de todos os trabalhos - é fundamentada em enredos e contextualizações que permitam a problematização, interpretação e investigação dos fatos e assuntos tratados no dia-a-dia do ensino escolar.

Para alcançar estes meios de aprendizagem, fundamenta-se nas interações entre a disciplina, meio e indivíduo, tratando das diferentes linguagens - que muitas vezes são subjetivas - da experiência prévia do aluno e das diferentes culturas das partes, atuando o professor como um mediador da discussão entre estas partes.

Durante todo do processo de aprendizagem, o aluno assume uma postura de protagonista, gerando conteúdo relevante no contexto da sociedade criada pelo colégio na busca por uma aprendizagem mais significativa.. 


\section{SEQUÊNCIA DIDÁTICA}

De acordo com Zabala (1998), sequências didáticas são:

"um conjunto de atividades ordenadas, estruturadas e articuladas para a realização de certos objetivos educacionais, que têm um princípio e um fim conhecidos tanto pelos professores como pelos alunos (...)". (Zabala,1998 p.18)

As sequências didáticas auxiliam na consolidação dos conhecimentos que estão sendo adquiridos e possibilita que, progressivamente, novas aquisições sejam possíveis. As atividades são organizadas de modo que haja o aprofundamento do tema que está sendo abordado e possuem diversificadas estratégias pedagógicas, como leituras, aulas dialogadas, filmes, experimentos, desafios, atividades individuais e em grupos, uso intencional da história da Matemática, entre outros. Partindo do levantamento dos conhecimentos prévios que o aluno traz, num conjunto de aulas que possibilitará uma diferenciação progressiva e uma reconciliação integradora do novo saber, permite-se ao aluno que ele se aprofunde e se aproprie do assunto em questão

No entanto, "apesar de projetar ser o traço mais característico da atividade humana" (Machado, 2000, p.7), temos que ter plena consciência que, ciente das metas e ações estabelecidas no presente, o futuro é indeterminado uma vez que sua concretização depende de diversas variáveis que podem alterar os resultados.

Desta reflexão e do contexto escolar cujos alunos tem contato reduzido com a Álgebra em função de um foco mais direcionado às Construções Geométricas e Números até o $7^{\circ}$ ano surgiu a seguinte sequência executada em grupos: 


\section{Atividade 1: "Bilhete Secreto"}

Objetivo: Despertar a curiosidade dos alunos em relação à Criptografia

$1^{\circ}$ Passo: Na aula anterior ao início da sequência, preparar o seguinte bilhete como lição de casa, cuja desafio é descobrir a mensagem escondida no bilhete:

$\begin{array}{ccccccccccccccc}\mathrm{O} & \mathrm{U} & \mathrm{D} & \mathrm{L} & \mathrm{S} & \mathrm{R} & \mathrm{M} & \mathrm{G} & \mathrm{N} & \mathrm{R} & \mathrm{L} & \mathrm{O} & \mathrm{S} & \mathrm{I} & \mathrm{M} \\ \mathrm{L} & \mathrm{E} & \mathrm{O} & \mathrm{U} & \mathrm{E} & \mathrm{A} & \mathrm{O} & \mathrm{O} & \mathrm{O} & \mathrm{A} & \mathrm{H} & \mathrm{E} & \mathrm{T} & \mathrm{O} & \mathrm{U} \\ \mathrm{A} & \mathrm{R} & \mathrm{S} & \mathrm{N} & \mathrm{N} & \mathrm{R} & \mathrm{S} & \mathrm{R} & \mathrm{M} & \mathrm{V} & \mathrm{O} & \mathrm{M} & \mathrm{E} & \mathrm{S} & \mathrm{N} \\ \mathrm{Q} & \mathrm{I} & \mathrm{A} & \mathrm{O} & \mathrm{T} & \mathrm{E} & \mathrm{A} & \mathrm{A} & \mathrm{A} & \mathrm{I} & \mathrm{S} & \mathrm{I} & \mathrm{R} & \mathrm{O} & \mathrm{D} \\ & & & & & & & & & & & & & & \\ \mathrm{O} & \mathrm{R} & \mathrm{O} & \mathrm{F} & \mathrm{I} & \mathrm{I} & \mathrm{M} & \mathrm{O} & \mathrm{I} & \mathrm{S} & \mathrm{A} & \mathrm{A} & \mathrm{V} & \mathrm{O} & \mathrm{E} \\ \mathrm{D} & \mathrm{I} & \mathrm{G} & \mathrm{I} & \mathrm{N} & \mathrm{A} & \mathrm{O} & \mathrm{S} & \mathrm{N} & \mathrm{T} & \mathrm{C} & \mathrm{T} & \mathrm{E} & \mathrm{C} & \mathrm{M} \\ \mathrm{A} & \mathrm{P} & \mathrm{R} & \mathrm{A} & \mathrm{I} & \mathrm{R} & \mathrm{S} & \mathrm{S} & \mathrm{V} & \mathrm{I} & \mathrm{A} & \mathrm{R} & \mathrm{S} & \mathrm{I} & \mathrm{A} \\ \mathrm{C} & \mathrm{T} & \mathrm{A} & \mathrm{E} & \mathrm{C} & \mathrm{E} & \mathrm{N} & \mathrm{A} & \mathrm{E} & \mathrm{G} & \mathrm{O} & \mathrm{A} & \mathrm{D} & \mathrm{N} & \mathrm{B}\end{array}$

Esta atividade foi aplicada como lição de casa de forma a instigar a curiosidade dos alunos para a descoberta da mensagem criptografada no bilhete.

Para a realização de tal atividade, como preparação prévia, a mensagem foi impressa em pequenos papéis (como bilhetes) e colocadas dentro de envelopes lacrados.

Ao final da aula, cada aluno recebeu um envelope, onde foi dito que havia uma mensagem secreta e eles precisariam descobrir o conteúdo da mensagem.

Na proposição desta atividade os alunos ficaram empolgados sentindo-se desafiados, com a possibilidade de desvendar uma "mensagem secreta" e queriam fazê-lo imediatamente. Entretanto, antes mesmo de abrirem o envelope, eles perguntaram se receberiam dicas de como decifrar a mensagem a qual eles ainda nem haviam visto.

Conforme os alunos perceberam que nenhuma dica seria dada, eles se apressaram em abrir o envelope para ver o conteúdo do mesmo.

À primeira vista, a mensagem parecia indecifrável. Foi o que todos disseram, nas três turmas em questão. No entanto, em poucos minutos, a maioria decifrou a mensagem escrita e foram para casa duplamente animados: $1^{\circ}$ Por terem decifrado a mensagem secreta; $2^{\circ}$ Por terem antecipado a tarefa de casa.

Nessa atividade, os alunos trabalharam apenas com os conhecimentos que eles já possuíam. 


\section{Atividade 2:}

Objetivos: Resgatar e analisar a tarefa de casa. Conceituar criptografia, e dar uma breve explicação sobre os diversos tipos existentes. Contar um pouco da história da Criptografia, em paralelo com a história do filme e seu contexto histórico: "O Jogo da Imitação".

$1^{\circ}$ Passo: Criptoanalisar a mensagem dada como lição de casa, utilizando as estratégias sugeridas pelos alunos.

Responda:

a) Qual é a mensagem oculta nela?

b) Como você a descobriu?

c) Utilizando a mesma lógica, criptografe a seguinte mensagem: "No meio da dificuldade, encontra-se a oportunidade". Albert Einstein

d) Você considera esse código com um nível de segurança alto ou baixo? Justifique.

$2^{\circ}$ Passo: Construir coletivamente o conceito de Criptografia. Discutir os níveis de segurança da mensagem que foi criptoanalisada, apresentar os conceitos de transposição e substituição dentro da criptografia.

$3^{\text {o }}$ Passo: Fazer um levantamento dos conhecimentos prévios do aluno, sobre a importância da criptografia para a humanidade.

$4^{\circ}$ Passo: Tratar de um episódio histórico em especial: a $2^{\text {a }}$ Guerra Mundial, através do filme que narra a história do Matemático Alan Turing.

$5^{\circ}$ Passo: Assistir ao filme: "O Jogo da Imitação"

Ficha técnica do filme

Nome: O jogo da imitação

Nome Original: The imitation game

Cor filmagem: Colorida

Origem: Inglaterra

Ano de produção: 2014

Gênero: Drama, Biografia

Duração: 114 min

Classificação: 12 anos

Direção: Morten Tyldum

Elenco: Benedict Cumberbatch, Keira Knightley, Matthew Goode, Charles Dance,Mark Strong, Matthew Beard, Allen Leech, Rory Kinnear 
Sinopse: O filme é baseado no livro Alan Turing: The Enigma, de Andrew Hodges. Durante a Segunda Guerra Mundial, o governo britânico monta uma equipe de inteligência que tem por objetivo decifras os códigos da máquina Enigma, usada pela Alemanha Nazista. Um de seus integrantes é Alan Turing, um matemático de 27 anos, focado e brilhante, mas com problemas de relacionamento, que não demora a liderar a equipe. Sua ideia é construir uma máquina que pense como o homem, e que seja capaz de analisar toda $\mathrm{s}$ as possibilidades de combinações em menos de 24 horas, de forma que os ingleses conheçam as ordens enviadas antes que elas sejam executadas.

Algumas questões para o debate: o momento histórico da humanidade; o perfil psicológico de Alan Turing e similaridades com outras pessoas; a questão da homossexualidade e da intolerância na Inglaterra e no mundo; reflexos das relações sociais; revolução científica (uso da enigma e a criação de Christopher); disputas em torno da verdade; algoritmos e resolução de problemas; o que é criptografia; panorama do século XX; o papel do Matemático nesse período; importância da criptografia naquele período histórico; Criptografia no século XXI.

No inicio dessa atividade, foi retomada a resolução da Atividade 1 com os alunos. Quando interpelados sobre como os mesmos tinham chego ao resultado, as respostas eram muito parecidas:

"Primeiro parecia impossível! As palavras não faziam sentido".

Levando em consideração a escrita da primeira linha, e o método de leitura ocidental:

$\begin{array}{llllllllllllllll}\mathrm{O} & \mathrm{U} & \mathrm{D} & \mathrm{L} & \mathrm{S} & \mathrm{R} & \mathrm{M} & \mathrm{G} & \mathrm{N} & \mathrm{R} & \mathrm{L} & \mathrm{O} & \mathrm{S} & \mathrm{I} & \mathrm{M}\end{array}$

"Depois, comecei a procurar palavras, como se fosse um caça- palavras. E foi então que eu descobri a palavra OLA, escrita na primeira coluna da esquerda”.

"Então, fui tentando ler desta maneira, de cima para baixo, e começou a fazer sentido".

A mensagem dizia: "Olá queridos alunos, entraremos agora no maravilhoso e misterioso mundo da criptografia e iniciaremos nossa investigação através do cinema".

Todos conseguiram criptoanalisar a mensagem.

Quando chegou o momento de criptografar, também não houve dificuldade. Conversamos apenas sobre a necessidade do nosso "retângulo" de letras ser completo por letras aleatórias. Desse modo, não ficaria nenhuma pista de que o texto havia sido escrito na vertical.

Então, a mensagem sugerida pela atividade ficou assim : 


$\begin{array}{ccccccccccc}\mathbf{N} & \mathbf{I} & \mathbf{D} & \mathbf{C} & \mathbf{A} & \mathbf{N} & \mathbf{T} & \mathbf{E} & \mathbf{O} & \mathbf{N} & \mathbf{D} \\ \mathbf{O} & \mathbf{O} & \mathbf{I} & \mathbf{U} & \mathbf{D} & \mathbf{C} & \mathbf{R} & \mathbf{A} & \mathbf{R} & \mathbf{I} & \mathbf{E} \\ \mathbf{M} & \mathbf{D} & \mathbf{F} & \mathbf{L} & \mathbf{E} & \mathbf{O} & \mathbf{A} & \mathbf{O} & \mathbf{T} & \mathbf{D} & \mathbf{C} \\ \mathbf{E} & \mathbf{A} & \mathbf{I} & \mathbf{D} & \mathbf{E} & \mathbf{N} & \mathbf{S} & \mathbf{P} & \mathbf{U} & \mathbf{A} & \mathbf{R}\end{array}$

Sobre o nível de segurança desta cifra, os alunos julgaram ser de baixa segurança. Afinal, eles conseguiram decifrar a mensagem muito rapidamente, sem muita dificuldade.

Em seguida, coletivamente, construímos uma definição para a palavra criptografia (assim como também o ato de criptografar e criptoanalisar). Definimos criptografia como "a ciência que esconde o significado das mensagens escritas". Foi contada um pouco sobre a importância da criptografia na história da humanidade, como em alguns momentos que foram narrados no capítulo sobre a história da criptografia.

Quando os alunos foram questionados sobre a existência de criptografia agora, no século XXI, eles trouxeram como referências: o código binário utilizado pelos computadores, falaram do código Morse e da criptografia que estava anunciada pelo aplicativos de comunicação Whatsapp e Telegram. No entanto, nesses últimos, embora eles recebessem o aviso que suas mensagens eram criptografadas, eles não conseguiam enxergar como isso era feito, já que suas mensagens estavam escritas na linguagem usual. No mais, a criptografia pra eles pareceu ser uma grande brincadeira, sem muita importância.

Depois assistiram o filme "O Jogo da Imitação" na escola, exibindo o filme completo, fazendo as devidas inferências do desenrolar da história de acordo com o roteiro de discussão sugerido na atividade. No filme, não só se mostra a colocação do Matemático contratado pelo governo, como também se mostra a importância da criptografia para a humanidade durante as grandes guerras e agora.

No desenrolar da história, mostra como os criptoanalistas tentavam descobrir padrões nas mensagens ou analisar as mensagens através da análise da frequência de cada letra.

O filme, nesse caso utilizado como organizador prévio, na perspectiva de Ausubel, Novak e Hanesian trouxe a II Guerra Mundial como um assunto conhecido e abrangente como pano de fundo, onde os alunos já possuíam alguma informação a respeito e aos poucos os novos conceitos da história da Criptografia e da vida de Alan Turing foram se conectando a esse conhecimento já existente e foi dando novo significado ao que os alunos já sabiam. 


\section{Atividade 3:}

Objetivos: Resgatar um pouco a história da Criptografia, em paralelo com a história da humanidade. Criptoanalisar mensagens de substituição e tentar descobrir o algoritmo para criptoanalisar a mensagem dada.

$1^{\circ}$ Passo: Contar um pouco sobre a história de Júlio César, o episódio em que Cícero estava encurralado pelos inimigos.

O primeiro documento que usou a cifra de substituição com finalidades militares está nas Guerras da Gália de Júlio César. Nela César narra como enviou uma mensagem para Cícero que estava cercado por inimigos e prestes a se render. César substituiu letras do alfabeto romano por letras gregas, o que tornou a mensagem incompreensível para o inimigo.

“O mensageiro recebeu instruções para que, se não pudesse se aproximar, jogasse uma lança com a mensagem amarrada por uma tira de couro, dentro das fortificações do campo... Com medo, o gaulês arremessou a lança como fora instruído. Por acaso a arma encravou-se em uma torre e passou dois dias sem ser vista pelos nossos soldados, até que, no terceiro dia, um soldado a viu, retirando-a e entregando a mensagem para Cícero. Ele a leu e depois a recitou em voz alta para a tropa em formação, trazendo grande alegria para todos". (Singh, p. 26)

O que será que essa mensagem quer dizer?

\section{OLJHLUD UDSRVD PDUURP VDOWRX VREUH R FDFKRUUR FDQVDGR}

$2^{\circ}$ Passo:

Responda,

a) Como você a descobriu?

b) Seria possível, estabelecer uma "fórmula" para criptoanalisar a mensagem? Explique.

c) Existe uma "fórmula" para criptografar a mensagem?Explique.

$3^{\circ}$ Passo: Apresentar o Código de Políbio

a) Que palavras são essas?

$$
121134113411 \quad 33114415331144241311
$$

b) Quais as semelhanças entre Código de Políbio e a Cifra de Júlio César? Qual parece mais segura?

$4^{\circ}$ Passo:

Exercício: Troca de bilhetes 
Cada dupla deverá escrever um bilhete para a dupla vizinha, utilizando a cifra de César.

Para essa atividade fiz uma pequena introdução histórica. Essa foi a primeira cifra de substituição que se tem registros históricos e foi utilizada por Júlio César.

Os alunos receberam, sem nenhuma orientação prévia, a seguinte mensagem:

\section{OLJHLUD UDSRVD PDUURP VDOWRX VREUH R FDFKRUUR FDQVDGR}

Sua missão novamente era descobrir qual era a mensagem oculta naquele bilhete.

Quando os alunos observaram a mensagem, também disseram que a mesma era indecifrável.

Depois os grupos começaram a seguir a estratégia sugerida no filme, e que resgatamos durante as discussões, referente à análise das frequências das letras na frase.

Aos poucos, eles foram percebendo, e o que era uma discussão em grupos, tornou-se uma discussão coletiva, que a letra $\mathrm{D}$ só poderia ser uma vogal, afinal estava iniciando a frase.

Daí partimos do princípio que das 5 possibilidades existentes: A,E,I,O U, só poderíamos iniciar a frase com $\mathrm{A}$ ou $\mathrm{O}$, então, reduzimos as possibilidades. $\mathrm{E}$ como determinar?

"Impossível descobrir qual será!” disse um aluno.

Outro aluno observou também, que a letra U dobrava em duas palavras PDUURP e FDFKRUUR. Pode ser RR ou SS, não é professora?

“Podemos testar?” Perguntou outro aluno.

$\mathrm{E}$ aos pouquinhos eles foram testando.

Vamos partir do princípio que o D seja A, isso significa que trocamos a letra A por D. Ou seja, que a letra $\mathrm{A}$ foi substituída por uma letra que está três posições à sua frente.

Seguindo esse princípio, A será D; B será E, e assim, sucessivamente.

Testando na frase, teremos:

\begin{tabular}{|l|l|l|l|l|l|l|l|l|l|l|l|l|l|l|l|l|l|l|l|l|l|l|l|}
\hline D & & O & L & J & H & L & U & D & & U & D & S & R & V & D & & P & D & U & U & R & P & \\
\hline A & L & I & G & E & I & R & A & & R & A & P & O & S & A & & M & A & R & R & O & M & \\
\hline
\end{tabular}

\begin{tabular}{|l|l|l|l|l|l|l|l|l|l|l|l|l|l|l|l|l|l|l|l|l|l|l|l|}
\hline $\mathrm{V}$ & $\mathrm{D}$ & $\mathrm{O}$ & $\mathrm{W}$ & $\mathrm{R}$ & $\mathrm{X}$ & & $\mathrm{V}$ & $\mathrm{R}$ & $\mathrm{E}$ & $\mathrm{U}$ & $\mathrm{H}$ & & $\mathrm{R}$ & $\mathrm{F}$ & $\mathrm{D}$ & $\mathrm{F}$ & $\mathrm{K}$ & $\mathrm{R}$ & $\mathrm{U}$ & $\mathrm{U}$ & $\mathrm{R}$ & \\
\hline $\mathrm{S}$ & $\mathrm{A}$ & $\mathrm{L}$ & $\mathrm{T}$ & $\mathrm{O}$ & $\mathrm{U}$ & & $\mathrm{S}$ & $\mathrm{O}$ & $\mathrm{B}$ & $\mathrm{R}$ & $\mathrm{E}$ & $\mathrm{O}$ & $\mathrm{C}$ & $\mathrm{A}$ & $\mathrm{C}$ & $\mathrm{H}$ & $\mathrm{O}$ & $\mathrm{R}$ & $\mathrm{R}$ & $\mathrm{O}$ & \\
\hline
\end{tabular}

\begin{tabular}{|l|l|l|l|l|l|l|}
\hline F & D & Q & V & D & G & R \\
\hline C & A & N & S & A & D & O \\
\hline
\end{tabular}


As turmas vibraram quando perceberam que as palavras foram começando a fazer sentido, e ficaram muito felizes por decifrarem a mensagem.

Será possível descobrir uma fórmula para criptografar as mensagens?

Um dos alunos perguntou: "Como assim, uma fórmula?"

Outro aluno respondeu: "É um jeito de generalizar, que serve para todo mundo, todas as vezes que for criptografar assim, não é professora?"

Então, este aluno foi perguntado como seria, respondendo "Fácil, cada letra menos 3".

Uma aluna disse: "Faz sentido, afinal, trocamos a letra D por A, e o A é exatamente menos três posições que a letra D”.

Foram perguntados novamente: Então para criptografar uma mensagem, teremos que voltar três letras sempre?

Até que outro aluno que parecia alheio à situação interveio na discussão: "Não. $\mathrm{Na}$ verdade, tem que ser a letra mais 3. Tem que ser o contrário do que estávamos fazendo!”

Foi pedido a ele que explicasse para a sala sua linha de raciocínio. Ele disse:

"A mensagem que nos foi dada estava em código, então foi preciso voltar cada letra três posições atrás, para descobrirmos qual era a mensagem. Mas agora, queremos fazer exatamente o contrário, então, temos que utilizar a operação inversa. Ao invés de subtrair 3, somar 3".

A turma parou para analisar um pouco, mas concordaram com a colocação do amigo. Embora somente alguns alunos tenham se colocado para comentar a tarefa na frente de todos, a sala inteira estava bem envolvida e atenta a cada pista que era descoberta.

Quando questionei sobre o nível de segurança dessa cifra, eles disseram que esta cifra era mais difícil do que a primeira, mas uma vez que eles conhecessem o jeito lógico de decifrar, ficava fácil.

Chamei a atenção deles nesse ponto: “É isso. Quando não conhecemos a regra, parece realmente impossível de decifrar e entender qualquer coisa. Uma vez que a regra é dada, basta observarmos com atenção para podermos aplicá-la."

Todos ficaram muito animados e queriam decifrar as mensagens da máquina enigma. Queriam aprender mais e mais códigos.

Logo após a cifra de César, lhes apresentei o código de Políbio.

De forma análoga ás vezes anteriores, partimos sem nenhuma orientação, apenas com o fato de serem palavras criptografadas. 
121134113411

33114415331144241311

E novamente, eles partiram para a análise da frequência dos números. Mas não conseguiam chegar em lugar nenhum, visto que havia muita repetição dos mesmos números e ausência de outros.

Durante essa fase, eles perguntaram se a mensagem havia sido criptografada apenas uma vez? Se estava em português?

Depois de deixa-los tentando por um tempo sem sucesso, dei algumas dicas:

Dica 1: Cada letra foi substituída por dois números.

Dica 2: Só foram utilizados os algarismos de 1 até 5.

Dica 3: A letra A é o número 11.

Dada a primeira dica, eles já tinham percebido que a letra A era 11.

Então, eles foram colocando todas as combinações de números possíveis, formados com os algarismos dados:

11121314152122232425313233343541424344455152535455

Pensando nisso, o problema estava praticamente resolvido. Até que um aluno observou, que tínhamos um problema: Como representar 26 letras, se só tínhamos 25 combinações disponíveis?

Outro aluno sugeriu que tirássemos alguma letra que não utilizamos muito, como K, W ou Y, mas qual delas?

E se excluirmos as letras com o mesmo som? Como $\mathrm{q} / \mathrm{k}$ ou $\mathrm{i} / \mathrm{y}$ ou ainda w/v w/u Outro aluno sugeriu?

E tornamos a perguntar? Mas qual?

Nesse momento eu estava em êxtase, pois era quase isso.

Então, compartilhei o fato de que Políbio escolheu, ao invés de excluir, utilizar o mesmo símbolo para K e Q e lhes foi apresentada a tábua oficial :

\begin{tabular}{|c|c|c|c|c|c|}
\hline & 1 & 2 & 3 & 4 & 5 \\
\hline 1 & A & B & $\mathrm{C}$ & D & E \\
\hline 2 & $\mathrm{~F}$ & $\mathrm{G}$ & $\mathrm{H}$ & I & $\mathrm{J}$ \\
\hline 3 & $\mathrm{~K} / \mathrm{Q}$ & $\mathrm{L}$ & M & $\mathrm{N}$ & $\mathrm{O}$ \\
\hline 4 & $\mathrm{P}$ & $\mathrm{R}$ & $S$ & $\mathrm{~T}$ & $\mathrm{U}$ \\
\hline 5 & V & W & $X$ & $Y$ & Z \\
\hline
\end{tabular}

Então, eles traduziram as palavras, que eram: BANANA E MATEMÁTICA.

Ao analisar a cifra de Políbio, perceberam que tinha um nível de segurança médio, como a de César, ambos eram códigos de substituição, mas o de Políbio fazia uma 
substituição numérica que utilizava mais de um símbolo para cada letra, e não utilizava todos os algarismos disponíveis, o que tornou o caminho um pouco mais difícil. Porém, não era uma cifra indecifrável.

Assim como a cifra de César, uma vez que se conhecessem as regras, a tabela, e a lógica de construção, ficava fácil.

Ao modo que os alunos foram se colocando como criptoanalistas para decifrarem as mensagens sugeridas, foi poissível estabelecer um diálogo entre passado e presente histórico, criando novos significados do conhecimento utilizado anteriormente pelos criptoanalistas.

\section{Atividade 4:}

Objetivos: Resgatar as cifras mencionadas no filme visto. Analisar as possibilidades de combinações para a escrita de cada palavra. Apresentação da história e Cifra de Blaise de Vigenere

a) História da Cifra de Vigenére.

b) Desafio de decifrar a mensagem: JGMG G GKS HULD PMENSGQ

c) Apresentação da Tabela da Cira de Vigenére e a utilização da palavra chave.

Questionamento:

- Quais são os aspectos positivos e negativos da Cifra de Vigenère?

- Quais os pontos em comum da Cifra de Blaise de Vigenère e as mensagens escritas pela máquina Enigma?

Contei a história de Blaise de Vigenére, que está no capítulo sobre a História da Criptografia.

Logo em seguida, os alunos receberam a mensagem e já foram aplicar as "técnicas" descobertas nas outras aulas.

Começando por analisar a frequências das letras e qual delas possivelmente será uma vogal. Mas ao realizar os experimentos, nenhuma das técnicas utilizadas fazia com que a frase fizesse sentido.

Então, lhes foi entregue a tabela com a Cifra de Vigenére.

Num primeiro momento, ficaram bem felizes, pois achavam que a tabela de Vigenére era parecida com a de Políbio, e que era apenas uma troca simples. Mas de nada adiantou a sua utilização. 
O fato de que o nível de segurança desta cifra era bem maior do que a das anteriores, quase impossível de ser decifrado lhes foi exposto. Esta cifra se trata de um código polialfabético, onde Vigenère utiliza 26 alfabetos. Além disso, cada letra tinha 26 possibilidades, e cada vez que era utilizada poderia ser escrita de uma forma diferente. $\mathrm{Ou}$ seja, a letra $\mathrm{G}$ por exemplo, aparece algumas vezes na frase, mas não representa a mesma letra.

Então inseri o conceito de palavra chave, explicado no capítulo sobre criptografia. Então retomamos a tabela e a mensagem.

E utilizando a palavra chave CSD, eles conseguiram criptoanalisar a mensagem, que dizia: "HOJE O DIA ESTÁ NUBLADO”!

Foi muito rápida a relação que eles fizeram com o filme, e as mensagens criptografadas pela máquina alemã Enigma. Foi quando as informações do filme realmente pareceram fazer sentido pra eles.

\section{Atividade 5: \\ Criação de uma cifra de códigos \\ $1^{\circ}$ Passo: Quais aspectos precisamos levar em consideração? \\ $2^{\circ}$ Passo: Será uma cifra de transposição ou substituição? \\ $3^{\circ}$ Passo: Qual será a regra para cifrar? \\ $4^{\circ}$ Passo: Dê um nome para a sua cifra. \\ $5^{\circ}$ Passo: Dar exemplos de criptografia e criptoanálise. \\ $6^{\circ}$ Passo: Apresentação e análise sobre as cifras criadas.}

A seguir, alguns exemplos de cifras criadas pelos alunos nessa atividade. Vale ressaltar, que todos eles se preocuparam em estabelecer padrões lógicos na elaboração de suas cifras, e não apenas realizar a troca de uma letra por um símbolo aleatório.

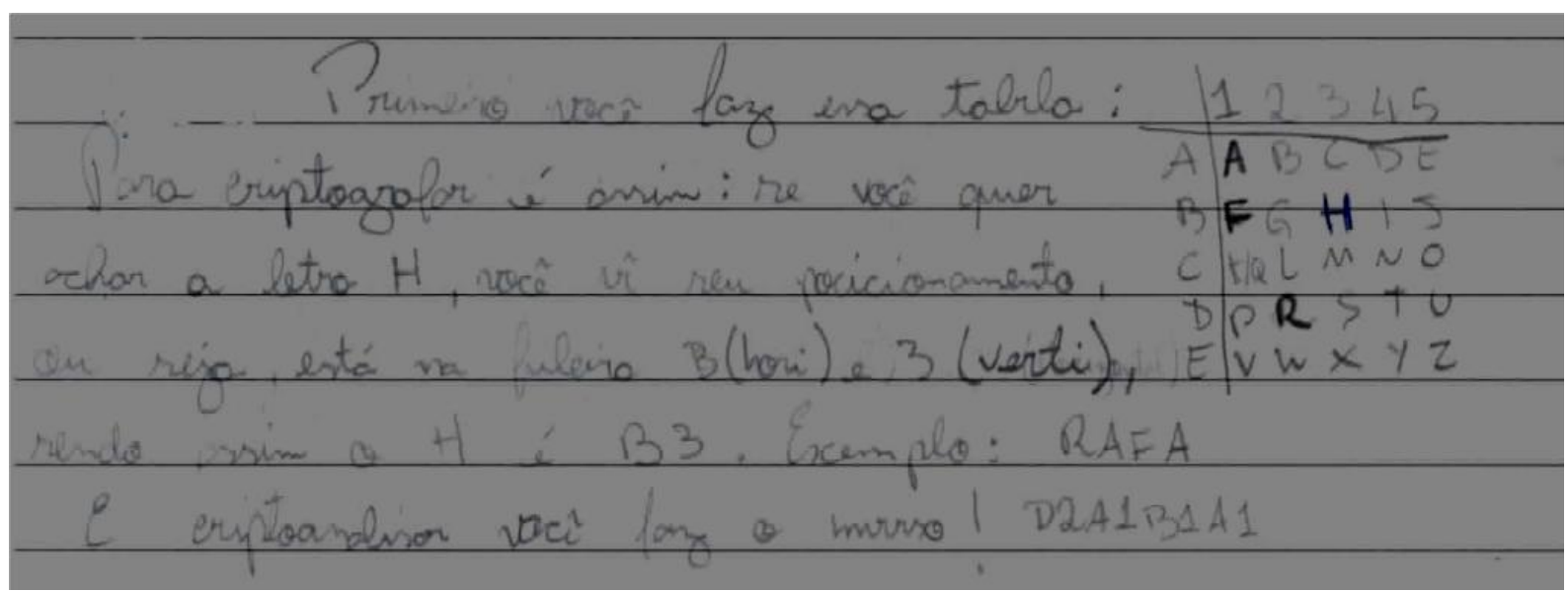


Cifra criada pelo aluno Rafael Marcon Krainovic

Nesse primeiro caso, inspirado pelo Código de Políbio, o aluno em questão substituiu cada letra por uma outra letra e um número. As letras que foram utilizadas foram A, B,C,D e E e os algarismos 1, 2, 3, 4 e 5. Sendo assim, obtemos 25 combinações possíveis entre os algarismos e as letras escolhidas para representar as letras do alfabeto. Como temos 25 letras no alfabeto, ele também utilizou a mesma combinação de letra e número para as letras $\mathrm{K}$ e Q.

Como cada letra é representada exatamente pela mesma quantidade de símbolos (uma letra e um algarismo), é possível fazer uma análise da frequência de cada letra para conseguirmos decifrar a lógica de construção da cifra apresentada.

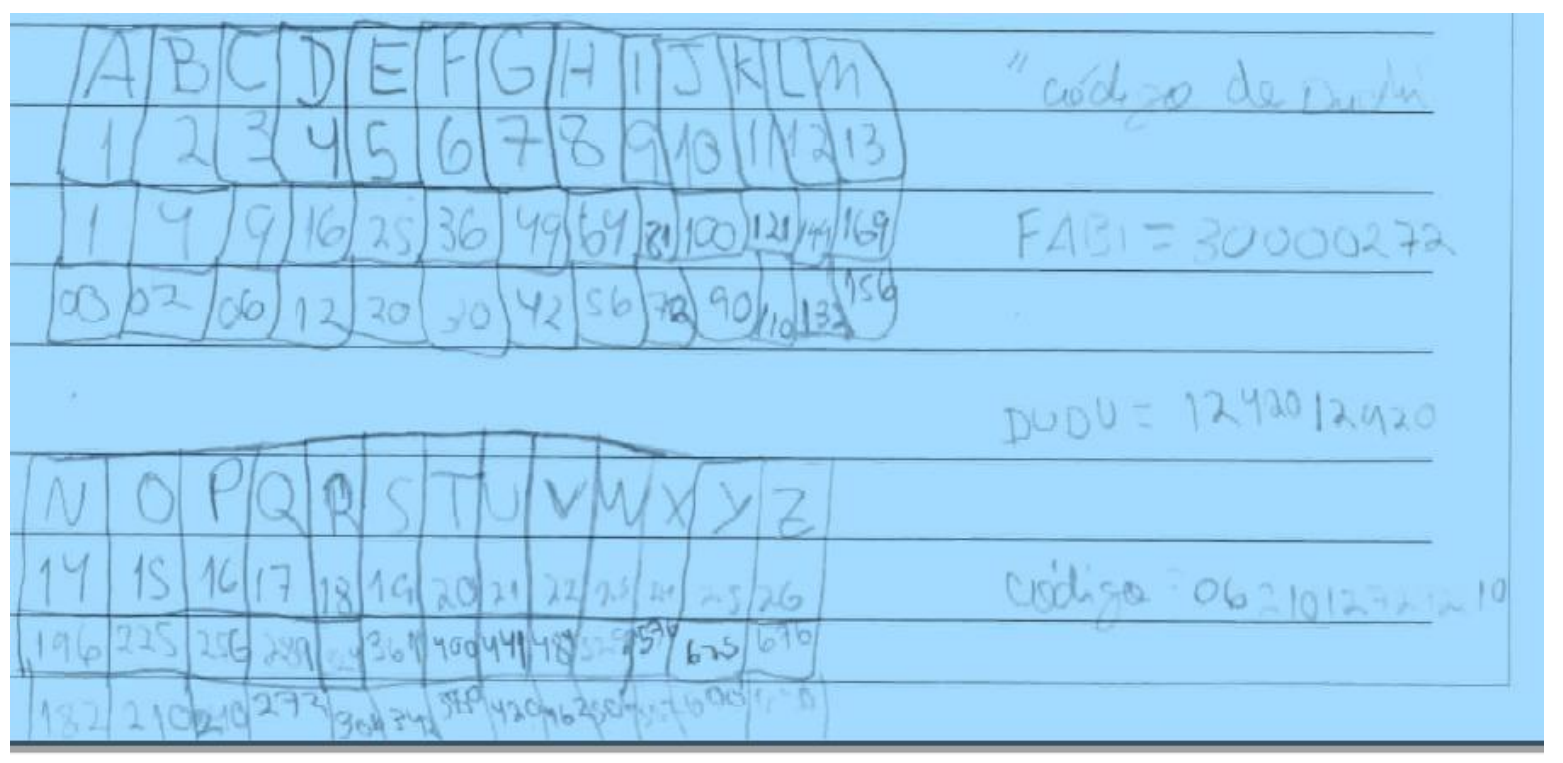

Cifra criada pelo aluno Luiz Eduardo Wrigg de Carvalho

Nessa cifra o aluno substituiu cada letra por um número, resultado de uma diferença. Primeiro ele enumerou o alfabeto de 1 até 26, depois calculou o quadrado de cada um desses números, e fez a diferença entre o quadrado do número e o próprio número, em cada caso. Obtendo assim, como resultado dessa diferença o número pelo qual ele substituiu cada letra.

Entretanto, o fato de cada letra poder ser substituída por números de dois ou três algarismos, dificulta a análise da frequência das letras.

Foi muito interessante pensar na cifra do aluno como uma fórmula da "cifra algébrica", uma metáfora da escrita algébrica, como sendo $\mathrm{x}^{2}-\mathrm{x}$, onde $\mathrm{x}$ é o número posicional da letra. 


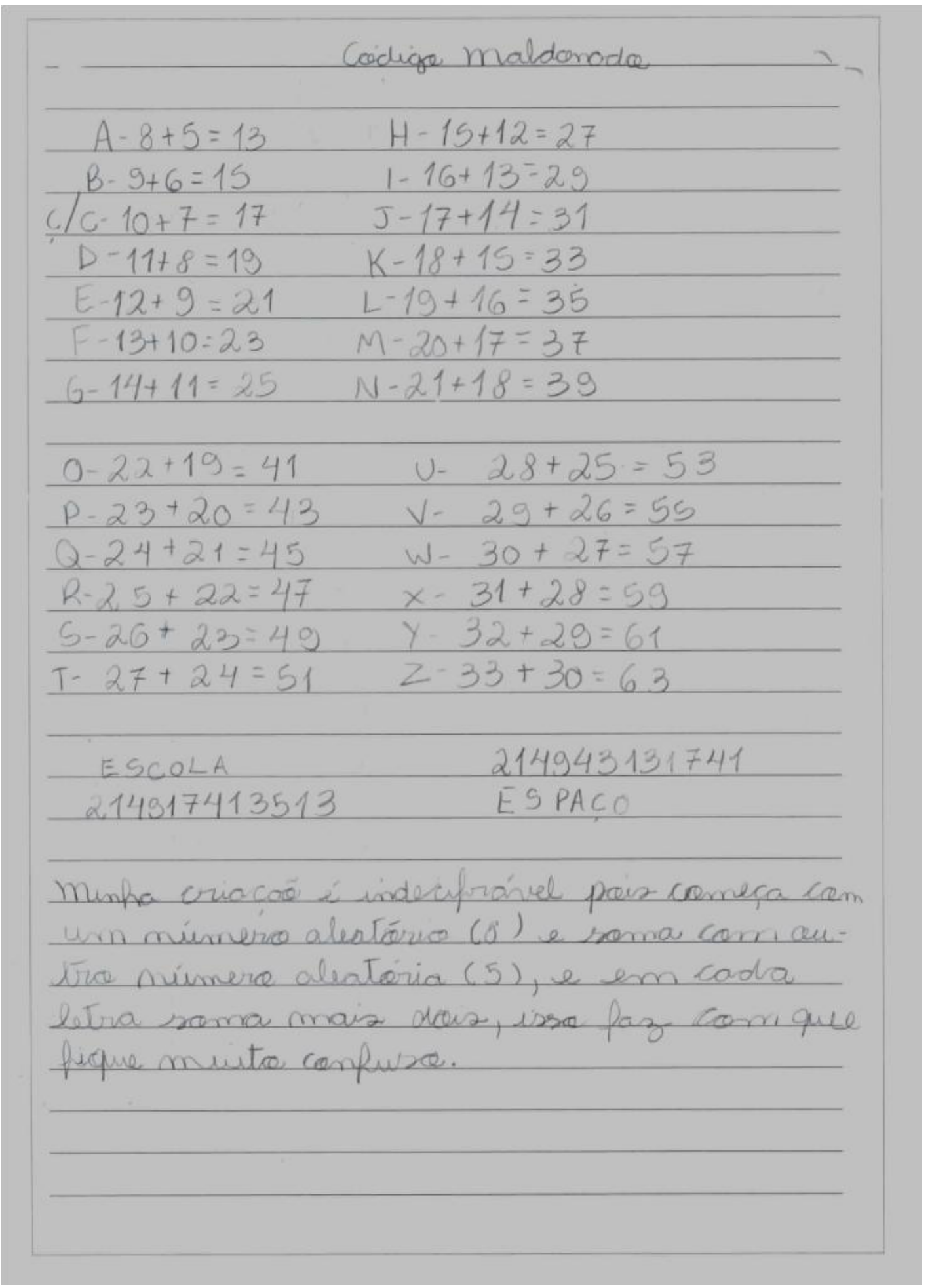

Cifra criada por Isabela Maria Bicudo Maldonado

Nessa cifra a aluna utilizou duas sequências paralelas de números inteiros e positivos. A primeira sequência iniciada por 8 e a segunda iniciada por 5. Cada letra será então representada pela soma dos termos de mesma posição de cada sequência numérica. Como o resultado sempre será um número com dois algarismos, fica mais fácil para analisar a 
frequência com que cada letra aparece. Mas a lógica de construção ainda é bem difícil de se descobrir, como foi justificado pela própria aluna na imagem,

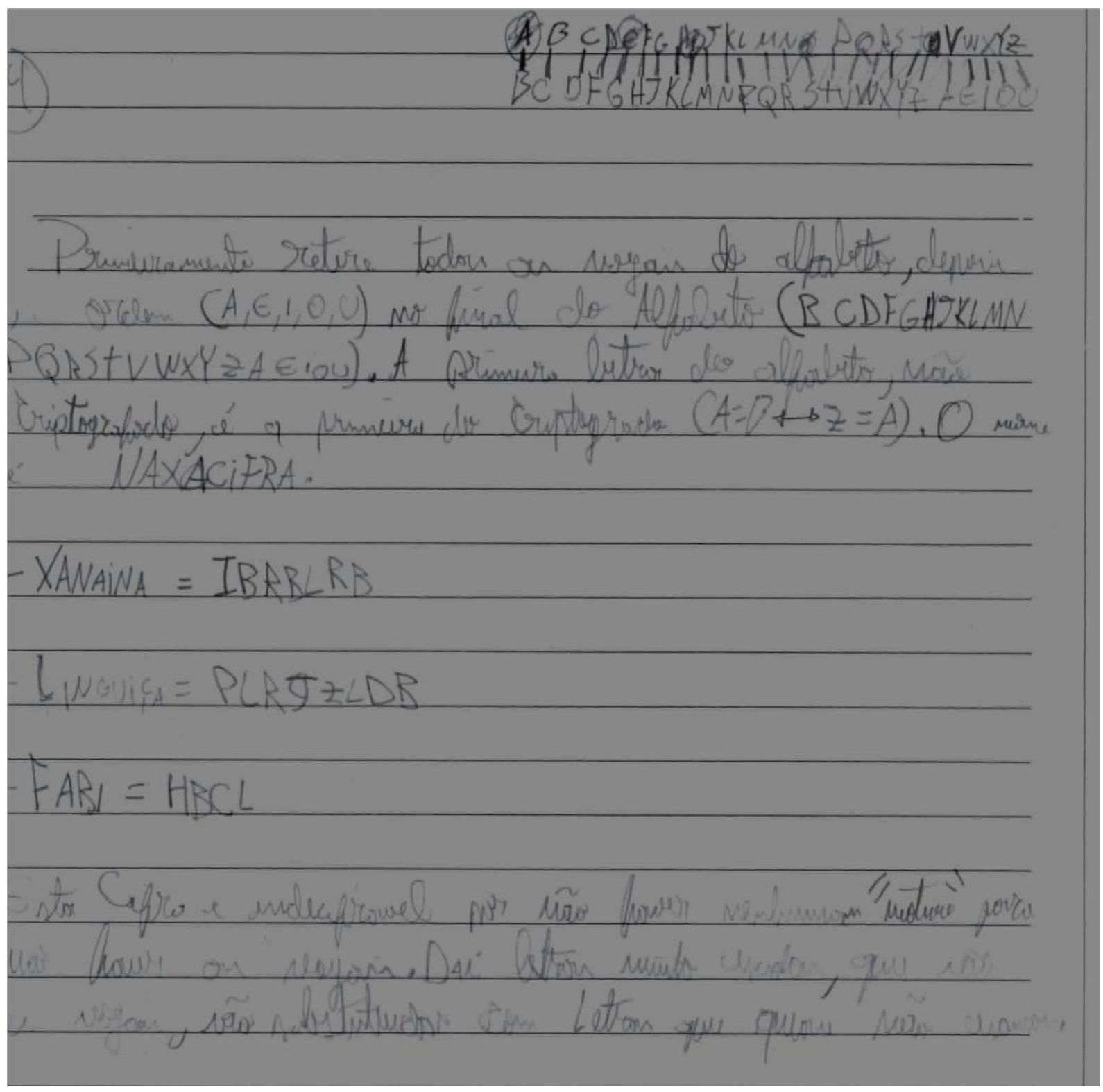

Cifra criada pelo aluno Tiago Arakaki.

O aluno em questão tirou as vogais e escreveu o alfabeto sem as mesmas, colocandoas no final. Criando assim um alfabeto com ordem diferente. A primeira letra do nosso alfabeto foi associada ao alfabeto criado por ele, e assim, baseado em cada posição, sucessivamente.

Alfabeto

\begin{tabular}{|l|l|l|l|l|l|l|l|l|l|l|l|l|l|l|l|l|l|l|l|l|l|l|l|l|l|}
\hline A & B & C & D & E & F & G & H & I & J & K & L & M & N & O & P & Q & R & S & T & U & V & W & X & Y & Z \\
\hline B & C & D & F & G & H & J & K & L & M & N & P & Q & R & S & T & V & W & X & Y & Z & A & E & I & O & U \\
\hline
\end{tabular}




\section{Alfabeto Cifrado}

Também é possível analisar a frequência de cada letra dentro de um texto e consequentemente, descobrir sua lógica de construção.

\section{Atividade 6:}

- Apresentação da História da Máquina Enigma, processo histórico de como a se deu a mecanização do sigilo.

- Através de pistas do filme e outras fontes de pesquisas, descobrir como funciona a Máquina Enigma.

Vide anexo.

A discussão dessa atividade foi feita como consequência do raciocínio utilizado para a atividade 4, naturalmente, no momento em que eles aprenderam o funcionamento da Cifra de Vigenère.

\section{Atividade 7: Avaliacão da Atividade}

Refletir e responder:

- O que mais gostou nas atividades?

- $\mathrm{O}$ que menos gostou nas atividades?

- O que você aprendeu de importante com essas atividades?

- O que gostaria de dizer sobre a atividade? Críticas, sugestões, comentários.

A avaliação é uma tarefa didática necessária e permanente do trabalho docente, que deve acompanhar passo a passo o processo de ensino e aprendizagem. Através dela os resultados que vão sendo obtidos no decorrer do trabalho conjunto do professor e dos alunos são comparados com os objetivos propostos a fim de constatar progressos, dificuldades, e reorientar o trabalho para as correções necessárias (LIBANEO, 1994, p.195).

A avaliação conjunta do processo é muito importante para se retomar os objetivos iniciais, analisar os resultados, progressos, dificuldades, avaliar outros caminhos e possibilidades para serem traçadas novas metas, novos objetivos. Objetivos estabelecidos em parceria, professor e aluno, para que juntos eles busquem uma aprendizagem com mais significado e tendo sempre a oportunidade de rever suas próprias atitudes. 
É importante, além de pedagógico, levar em consideração todas as perspectivas do trabalho, para que os alunos sejam de fato protagonistas nessa construção do conhecimento.

Nesse contexto escolar onde me encontro, conversar com os alunos sobre os caminhos que serão percorridos na disciplina, o "making off” de cada trabalho é algo trivial, assim como, escutar a opinião e sugestão dos alunos, no processo de construção do conhecimento.

No entanto, apesar de ser algo trivial, assim como a proposta de um trabalho mais enredado para buscar mais relações e significados, os alunos pareceram muito mais motivados e participativos durante todo o processo.

Então, essa avaliação foi feita num círculo(proposto pelos próprios alunos) de discussão e foi bastante proveitosa. Todos foram unânimes em dizer que gostaram muito de conhecer as diferentes "formas" de escrita, por meio das cifras. E três colocações foram muito marcantes:

" $O$ que mais foi legal nessa atividade, foi o fato de eu ter me tornado um criptoanalista, como Alan Turing. Eu descobri sozinho todas as cifras!” -

“ Nossa, descobrir que a Matemática foi tão importante numa guerra, foi muito importante pra mim. A gente escuta que a Matemática está em tudo, tudo, mas na boa eu não consigo ver. Eu não consigo ver aquelas equações no meu dia- a dia, Deus me livre! Mas eu percebo agora a sua importância para a humanidade, através da história, e com certeza terei mais respeito pela matéria. Ainda não sei se gosto da Matemática como um todo, mas gosto desse jeito que ela faz a gente pensar .... sabe, prof.?"

"Foi muito legal. Eu gostaria de conhecer um pouco mais da história, com participação da matemática. Saber afinal, o que as pessoas estavam pensando na hora que inventaram essa maluquice toda, talvez assim, eu consiga encarar tudo como cifras que precisam ser decifradas. "

Os três depoimentos são de alunos com muitas dificuldades em matemática, e que mesmo assim assumiram um papel de protagonistas na investigação de cada criptoanálise. 


\section{SUGESTÃO}

Ao decorrer da aplicação das sequências didáticas, tive contato com o conto " $\mathrm{O}$ Escaravelho de Ouro" do Edgar Allan Poe, que traz uma história de ficção e investigação interessante e que traz a criptografia para solucionar os mistérios narrados no conto. Sua leitura é muito enriquecedora, e a maneira como trata a cifra de substituição utilizada é muito pertinente para a discussão com os alunos.

Futuramente, aplicarei a $8^{\mathrm{a}}$ atividade, conforme abaixo:

$1^{\circ}$ Passo: Leitura compartilhada do texto (Em anexo).

$2^{\circ}$ Passo: Breve discussão sobre o conto e seus aspectos investigativos.

$3^{\circ}$ Passo: Análise da lógica utilizada na construção da cifra utilizada no conto.

$4^{\circ}$ Passo: Sugerir que cada grupo crie seu conto, baseado na atualidade, onde a criptografia seja a grande protagonista para decifrar o mistério.

Toda essa sequência didática o papel do professor nestas atividades foi de mediadora, ajudando-os no processo por descoberta de cada algoritmo, apresentando alguns elementos da História da Matemática e da Criptografia deixando a descoberta de cada código por conta dos alunos.

\section{PRINCIPAIS APRENDIZADOS}

A aplicação da sequência didática em grupos permitiu que as diferentes realidades fossem conectadas, atribuindo a cada indivíduo uma participação importante na descoberta do conhecimento.

Partindo da complexidade do contexto, o cinema através do filme "O Jogo da Imitação" como organizador prévio, como sugere Ausubel, Novak e Hanesian, aproximou o aluno do conteúdo e permitiu interrelações posteriores, por meio de uma linguagem atual e simples, possibilitou a problematização, a investigação e a interpretação dos fatos de modo que os alunos fossem protagonistas na criação do conhecimento relevante à sociedade em que estão envolvidos.

À medida que o aluno entendia como as coisas foram se desenvolvendo no decorrer da história, começaram a perceber e aceitar de forma mais natural que nem todo o conhecimento estudado é utilizável no seu cotidiano, mas que o modo de pensar matemático que cada conteúdo traz é importante para o cotidiano. 
Ainda na esfera da educação, a utilização do filme permite mostrar outra perspectiva da $2^{\mathrm{a}}$ Guerra Mundial, não só a estudada em livros de história, mas sim uma perspectiva matemática sobre como os fatos se deram, através da criptografia e estatística. Colocando a criptoanálise das mensagens da Enigma como ponto principal para diminuir o tempo da Guerra e garantir a vitória para a Inglaterra e seus aliados.

Esta perspectiva, fez com que dentro da aula de Matemática fosse proposto um tema mais amplo que permita uma discussão interdisciplinar e transdisciplinar, um dos pontos principais da proposta pedagógica do Colégio em que a atividade foi aplicada.

Mostrar para os alunos que a criptografia tinha tido um papel importante na história da humanidade, que não era mera brincadeira de criança, foi vital para o envolvimento e permissão para a mediação na criação do novo conhecimento.

Atribuir o processo de descoberta, atuando apenas como uma mediadora e facilitadora na construção do conhecimento, gera um envolvimento, interesse e expectativa dos alunos muito maior do que em uma aula expositiva comum.

Nesta trajetória, quando introduzida a linguagem algébrica da forma tradicional e estruturada, os alunos a encararam como uma criptoanálise, buscando o conhecimento das regras de construção da mesma forma como as cifras e regras de transposição e substituição que foram utilizadas na sequência didática.

Tendo como base a perspectiva sócio-cultural desenvolvida por Radford e Furinghetti a História da Humanidade, da Matemática e em especial da Criptografia nos ajudou a conceber um conhecimento geral, resultante da negociação de significados da atividade social dos indivíduos, no contexto cultural ao qual estão inseridos, primeiramente por Alan Turing e seu grupo durante a guerra, e agora pelos alunos e suas interações com a tecnologia e o meio que os cerca. O conhecimento Matemático concebido nesse caso, se deu através de experiências compartilhadas, num diálogo entre passado e presente e através da troca de experiências e conhecimentos prévios que os alunos já tinham e que permitiram a construção de novos significados.

A História da Matemática nos permitiu uma experiência com mais significado, pois não possibilitou apenas a inserção de conceitos e princípios científicos, mas também a reflexão crítica dos mesmos agregando valores à ação da humanidade. 


\section{CONSIDERAÇÕES FINAIS}

A partir do momento em que passei por uma mudança profissional me vi inserida em um contexto totalmente novo, bem diferente do ensino tradicional. Nesta nova realidade, os conhecimentos são questionados e ressignificados através de uma construção coletiva e experiências compartilhadas. A busca por uma aprendizagem com mais significado, através de um conteúdo enredado, é constante e todos são protagonistas na construção do saber.

Foi então que eu comecei a questionar a maneira com a qual eu estava ensinando Matemática e senti a necessidade de me reencontrar nesse novo contexto. Portanto, os caminhos e metodologias escolhidas e percorridas estão em concordância com essa minha nova realidade e, de certa forma, e metaforicamente falando, narram a minha trajetória até aqui.

Refletir sobre a minha prática e buscar uma transformação no ensino e aprendizagem para se buscar uma aprendizagem significativa, tornou-se então minha principal motivação através desse trabalho.

O primeiro passo de questionamento da própria prática não é algo natural. Principalmente quando já lecionamos há mais de dez anos, num mesmo sistema apostilado, com as aulas pré-elaboradas e cuja contextualização se limita as caixas de texto que introduzem as questões. Em alguns momentos, é preciso uma situação extraordinária para nos fazer pensar. E para nos fazer reconhecer que há múltiplas relações entre o contexto, o saber e o indivíduo.

Depois de toda essa trajetória descrita nesse trabalho, me pergunto: É possível buscar uma aprendizagem significativa? Nem sempre encontraremos meios para buscar uma aprendizagem significativa, mas a busca deve ser constante.

Não existe uma sequência perfeita, capaz de conectar todos os saberes matemáticos disponíveis na estrutura cognitiva do aluno, em todos os assuntos sempre. Entretanto, essa experiência da busca foi e está sendo muito enriquecedora e trouxe aprendizados muito valiosos para a minha prática docente, me permitiu o contato pessoal com instrumentos como a História da Matemática, o Cinema e a Criptografia que até o momento haviam sido apenas teóricos. Agora, posso dizer por mim que:

- A História da Matemática é sim um instrumento inspirador para a elaboração de atividades que sejam contextualizadas, permitindo uma discussão mais ampla e possibilitando conexões com outras disciplinas. Além de proporcionar situações mais significativas, uma vez que contextualizadas e por ser um arcabouço de experiências humanas. Essa proximidade 
com as ditas humanidades faz com que o aluno enxergue a Matemática não mais como uma ciência dura, cheia de verdades absolutas, e sim como uma ciência em construção, humana, e mais uma perspectiva para se enxergar o mundo.

O fato é que a abordagem da História da Matemática deve ser algo muito planejado. Não pode ser feita ao acaso e superficialmente, como naqueles pequenos relatos dos livros didáticos. E aí, cabe a nós professores, uma atitude investigativa ainda mais profunda. Atitude esta que quer dizer sair dos limites da Matemática para propor e criar outras significações e vínculos com as demais áreas do conhecimento.

Além disso, temos que nos preocupar com a maneira através da qual iremos comunicar essa História.

É nesse contexto que entra o cinema. Ter escolhido o cinema como organizador prévio, foi uma escolha feliz. Pois se trata de uma linguagem simples e pude contar com um recurso audiovisual para despertar o senso crítico e investigativo do aluno. Utilizar o cinema como um organizador prévio me ajudou a despertar o interesse dos alunos em assuntos que eles, normalmente, não se interessariam, como a história de Alan Turing, e que trouxe tantas reflexões interessantes.

- A criptografia tornou-se um ótimo assunto para se introduzir a álgebra, pois tira essa visão estigmatizada que a maioria tem em relação a esse conteúdo e ajuda a estabelecer um diálogo do passado com o presente, na construção de novos significados.

É claro que a Matemática é uma ciência abrangente, mas é preciso mais atitude para se buscar uma potência maior no que está explícito. E consequentemente, estar disposto a se submeter e a fazer outras experiências. A acertar e errar, mas sempre saber avaliar as situações de modo a aprender alguma coisa de cada situação vivida. É preciso estar disposto a estar em constante transformação.

Além disso, é muito importante demonstrar para o aluno esse esforço da busca por um ensino mais significativo para inspirar e "contaminar" os alunos para a busca de experiências que também lhes proporcionem uma aprendizagem significativa.

(...) fazer uma experiência com algo significa que algo nos acontece, nos alcança; que se apodera de nós, que nos tomba e nos transforma. Quando falamos em "fazer" uma experiência, isso não significa precisamente que nós a façamos acontecer, "fazer" significa aqui: sofrer, padecer, tomar o que nos alcança receptivamente, aceitar, à medida que nos submetemos a algo. Fazer uma experiência quer dizer, portanto, deixar-nos abordar 
em nós próprios pelo que nos interpela, entrando e submetendonos a isso. Podemos ser assim transformados por tais experiências, de um dia para o outro ou no transcurso do tempo (LARROSA,2014, p.27).

Realizar esse trabalho me permitiu fazer uma experiência de mim mesma como educadora e experimentar uma aprendizagem significativa não só para o meu aluno, mas para mim também enquanto educadora humana. Afinal os conteúdos do ensino de Matemática não são apenas os conceitos e os princípios científicos que constituem a disciplina, mas os valores que dão sentido à ação humana.

Status atual: Em transformação. 


\section{BIBLIOGRAFIA}

AUSUBEL, D.P. (2003). Aquisição e Retenção de Conhecimentos: Uma Perspectiva Cognitiva. Lisboa: Plátano Edições Técnicas.

AUSUBEL, D.P.; NOVAK, J.D. e HANESIAN, H. (1980). Psicologia Educacional. Rio de Janeiro: Editora Interamericana.

AUSUBEL, D. P. A aprendizagem significativa: a teoria de David Ausubel. São Paulo: Moraes, 1982.

AZEVEDO, J. G. A Tessitura do Conhecimento em Redes. In: OLIVEIRA, Inês Barbosa de. (org) Pesquisa no /do cotidiano das escolas sobre redes de saberes. Rio de Janeiro: DP\&A, 2001.

Brasil. Secretaria de Educação Fundamental. Parâmetros curriculares nacionais : Matemática / Secretaria de Educação Fundamental. Brasília : MEC / SEF, 1998.

BROUSSEAU, G. Introdução ao estudo da teoria das situações didáticas: conteúdos e métodos de ensino. São Paulo: Ática, 2008.

CHEVALLARD, Y. La transposición didáctica: del saber sabio al saber enseñado. Buenos Aires: Aique, 1991.

CÔRTEZ, H. S. Uso pedagógico do cinema: estratégias para explorar e avaliar filmes em sala de aula. In: GRILLO, Marlene Correro; GESSINGER, Rosana Maria; FREITAS, Ana Lúcia Souza de ... [et al]. Por que falar ainda em avaliação? [recurso eletrônico]. Porto Alegre: Edipucrs, 2010. p. 63-83. Disponível em: <http://www.pucrs.br/orgaos/edipucrs/>. Acesso em 04 abr. 2012.

COUTO, S, P. Códigos \& Cifras - Da antiguidade à Era Moderna. Rio de Janeiro, Editora Nova Terra; 2008. 
KLAUSMEIER, H. J.; GOODWIN, W. Manual de Psicologia Educacional: aprendizagem e capacidades humanas (M. C. T. A. Abreu, Trad.). São Paulo: Editora Harper \& Row, 1977.

MIGUEL, A., MIORIM, M. A. História na Educação Matemática - Propostas e desafios. Belo Horizonte: Autêntica, 2004.

MOREIRA, Marco Antonio. Aprendizagem significativa. Brasília: Ed. da UnB, 1998.

MOREIRA, Marco Antonio. APRENDIZAGEM SIGNIFICATIVA: da visão clássica à visão crítica (Meaningful learning: from the classical to the critical view). In: Conferência de encerramento do V Encontro Internacional sobre Aprendizagem Significativa, Madrid, Espanha, setembro de. 2006.

MOTA, C. D. V. B., História da matemática na educação matemática: espelho ou pintura? Santos, SP: Comunnicar, SP.

NOVAK, J.D. (1998). Conocimiento e Aprendizaje: Los mapas conceptuales como herramientas facilitadoras para escuelas y empresas. Madrid: Editorial Alianza.

NOVAK, J.D. e GOWIN, D. B. (1999) Aprender a aprender. Lisboa: Plátano Edições Técnicas.

NOVAK, J.D.; MINTZES, J.J. e WANDERSEE, J.H. (Ed.) (2000). Ensinando ciência para a compreensão: Uma visão construtivista. Lisboa: Plátano Edições Técnicas.

NOVAK, J. D.; GOWIN, D. B. Teoria y practica de la educación. 1988.

PAIS, L. C. Didática da Matemática: uma análise da influência francesa. Belo Horizonte: Editora Autêntica, 2002.

PIAGET, J.; GARCIA, R. Psicogênese e História das Ciências. Lisboa: Publicações Dom Quixote, 1987. 
PIRES, C. M. C, Currículos de matemática: da organização linear à ideia de rede - São Paulo, FTD, 2000.

RADFORD, L. On Psychology, Historical Epistemology, and the Teaching of Mathematics: towards a Sócio-Cultural History of Mathematics. For the Learning of Mathematics 17, 1, p. 26-33, february, 1997.

SINGH, S., O livro dos Códigos - Rio de Janeiro: Record, 2001.

SOUTO, R. M. A, Cinema e História da matemática: entrelaços possíveis - São Paulo: Editora Livraria da Física, 2013.

VALENTE, W. R. História da Matemática Escolar no Brasil. In: Anais do IV Seminário Nacional de História da Matemática, p. 207-219. Natal - RN. Editora da SBHMat, Rio Claro, 2001.

Base Nacional Curricular

http://basenacionalcomum.mec.gov.br/documentos/bncc-2versao.revista.pdf Acesso em 19 de Outubro de 2016.

SEVERINO, Antonio Joaquim. O conhecimento pedagógico e a interdisciplinaridade: o saber como intencionalização da prática. In FAZENDA, Ivani C. A. (org.) Didática e interdisciplinaridade. 8a ed. São Paulo: Papirus, 2003.

MORIN, Edgar. Os sete saberes necessários à educação do futuro, UNESCO/Cortez Editora, cap. III e IV, p. 47-78, e cp. VI, 93-104, 2000.

MORIN, Edgar. Introdução ao Pensamento Complexo. Tradução Eliana Lisboa, 5.ed. - Porto Alegre: Sulina, 2015.

MOREIRA, Marco A. Aprendizagem significativa crítica. Porto Alegre. 2005

DA CONCEIÇÃO, Dalva Batista; MENDES, Andréia Almeida; DE FÚCIO BORGES, Lidiane Hott. ANÁLISE DOS FATORES QUE DESMOTIVAM/DESINTERESSAM OS 
ALUNOS COM RELAÇÃO À MATEMÁTICA. Anais do Seminário Científico da FACIG, n. 1, 2017.

DA CRUZ, EDILSON FERNANDES. "A CRIPTOGRAFIA E SEU PAPEL NA SEGURANÇA DA INFORMÇÃO E DAS COMUNICAÇÕES (SIC)-RETROSPECTIVA, ATUALIDADE E PERSPECTIVA." (2009).

MOREIRA, M. A.. Enseñanza de la Física: aprendizaje significativo, aprendizaje mecánico y criticidad. Revista de Enseñanza de la Física, v. 26, p. 45-52, 2014 https://www.if.ufrgs.br/ moreira/ORGANIZADORESport.pdf . Acesso em 06 de Abril de 2017.

LIBÂNEO, José Carlos. Didática. Cortez Editora: São Paulo, Coleção Magistério $2^{\circ}$ Grau Série Formando Professor, 1994. 


\section{ANEXOS \\ O GANSO QUE JAMAIS GRASNAVA (A HISTÓRIA DA ENIGMA)}

Por treze anos os britânicos e os franceses tinham acreditado que a cifra Enigma era indecifrável, mas agora havia uma esperança. As revelações dos poloneses tinham demonstrado que a cifra tinha falhas, o que aumentou o moral dos criptoanalistas aliados. $\mathrm{O}$ progresso polonês parara com a introdução de novos misturadores e de novos cabos de ligação, mas permanecia o fato de que a Enigma não era mais considerada uma cifra perfeita. Os avanços poloneses também demonstraram para os aliados o valor de empregar matemáticos como decifradores de códigos. Na Inglaterra, a Sala 40 sempre fora dominada por linguistas e especialistas nos clássicos, mas agora havia um esforço concentrado para equilibrar a equipe com matemáticos e cientistas. Eles foram recrutados principalmente por uma rede de velhos companheiros, com aqueles que trabalhavam na Sala 40 contatando seus ex-colegas de Oxford e Cambridge. Havia também uma rede de amigas, que recrutava mulheres, estudantes universitárias de instituições como o Colégio Newnham e o Colégio Girton, em Cambridge.

Os novos recrutas não eram levados para a Sala 40, e sim para Bletchley Park, em Buckinghamshire, onde ficava a sede da Escola de Cifras e Códigos do Governo (GC\&CS), uma nova organização para a quebra de códigos que tomaria o lugar da Sala 40. Bletchey Park podia alojar uma equipe muito maior, o que era importante devido à enchente de mensagens cifradas que era esperada assim que a guerra começasse. Durante a Primeira Guerra Mundial a Alemanha transmitira dois milhões de palavras por mês, mas previa-se que a maior disponibilidade de rádios na Segunda Guerra Mundial resultaria na transmissão de dois milhões de palavras por dia.

No centro de Bletchley Park havia uma grande mansão vitoriana, em estilo Tudor-gótico, que fora construído no século XIX pelo financista Sir Herbert Leon. Com sua biblioteca, salão de jantar e salão de bailes decorado, a casa serviria de escritório central para toda a operação em Bletchley. O comandante Alastair Denniston, diretor do GC\&CS, tinha um escritório no andar térreo com vista para os jardins. Vista que logo foi prejudicada pela construção de numerosas casinhas de madeira. Essas construções alojavam as várias atividades de quebra de códigos. Por exemplo, a Casa 6 era especializada na análise das comunicações do exército alemão pela Enigma. A Casa 6 passava suas mensagens decifradas para a Casa 3, onde operadores de espionagem traduziam as mensagens e tentavam usar suas informações. A Casa 8 se 
especializava na versão naval da Enigma e passava suas decifragens para a Casa 4, para tradução e coleta de informações. Incialmente a equipe de Bletchley Park era formada por duzentas pessoas, mas em cinco anos a mansão e suas casas alojariam sete mil homens e mulheres.

Durante o outono de 1939 os cientistas e matemáticos de Bletchley aprenderam as minúcias da cifra Enigma e rapidamente dominaram as técnicas polonesas. Bletchley contava com mais recursos e uma equipe maior do que o Biuro Sztfrów polonês, e assim eles foram capazes de lidar com uma seleção maior de misturadores e com o fato de que a Enigma era agora dez vezes mais difícil de decifrar. A cada vinte e quatro horas os decifradores de códigos britânicos passavam pela mesma rotina. Á meia-noite, os operadores alemães das Enigmas mudavam para uma nova chave diária e, nesse ponto, quaisquer avanços que a equipe de Bletchley tivesse feito no dia anterior não poderiam mais ser usados para decifrar as mensagens. Os decifradores agora tinham que recomeçar o trabalho de identificação da nova chave diária. Isso levava várias horas, mas assim que descobriam os ajustes da Enigma para aquele dia, a equipe de Bletchley poderia começar a decifrar as mensagens alemãs que já tinham se acumulado, revelando informações inestimáveis para o esforço de guerra.

A surpresa é uma arma preciosa para o comandante que puder contar com ela. Mas se Bletchley podia decifrar a Enigma, os planos dos alemães tornavam-se visíveis, como se os britânicos fossem capazes de ler as mentes do Alto Comando Alemão. Se os britânicos pudessem captar a notícia de um ataque iminente, eles poderiam enviar reforços ou adotar uma ação evasiva. E se pudessem decifrar os debates dos alemães quanto a suas próprias fraquezas, os aliados poderiam focalizar suas ofensivas. As decifragens de Bletchley foram da maior importância. Por exemplo, quando a Alemanha invadiu a Dinamarca e a Noruega em Abril de 1940, Bletchley forneceu uma imagem detalhada das operações alemãs. De modo semelhante, durante a Batalha da Inglaterra, os criptoanalistas foram capazes de dar um alerta prévio dos ataques dos bombardeiros, incluindo as horas e os locais. Eles também podiam fornecer dados continuamente atualizados sobre o estado da Luftwaffe, tais com o número de aviões que tinham sido perdidos e a velocidade com que estavam sendo substituídos. Bletchley enviava toda essa informação para a sede do MI6, que os passava para o Ministério da Guerra, o Ministério da Aeronáutica e o Almirantado.

Enquanto influenciavam o desenrolar da guerra, os criptoanalistas às vezes ainda achavam tempo para relaxar. De acordo com Malcolm Muggeridge, que atuou no serviço secreto e visitou Bletchley, um passatempo favorito era o jogo de rounders, semelhante ao beisebol: 
Todo o dia, depois do almoço, se o tempo estivesse propício, os quebradores de códigos jogavam uma partida no jardim da mansão, assumindo uma atitude de meio séria ante uma atividade que seria considerada frívola e insignificante em comparação com seus estudos. Assim eles discutiam sobre algum detalhe do jogo com o mesmo fervor com que poderiam questionar o determinismo e o livre-arbítrio, ou se o mundo começara com o big bang ou era o resultado de um processo de criação contínua.

Depois de dominar as técnicas polonesas, os criptoanalistas de Bletchley começaram a inventar seus próprios atalhos para encontrar as chaves da Enigma. Por exemplo, eles aproveitaram o fato de que os operadores alemães da Enigma ocasionalmente escolhiam chaves de mensagens óbvias. Para cada mensagem o operador deveria selecionar uma chave de mensagem diferente, três letras selecionadas ao acaso. Contudo, no calor da batalha, no lugar de forçar a mente para bolar uma chave casual, os operadores cansados às vezes pegavam três letras consecutivas do teclado da Enigma, tais como QWE ou BNM. Essas chaves de mensagem previsíveis se tornaram conhecidas como cílios.

Outro tipo de cílio era o uso repetido da mesma chave de mensagem, talvez as iniciais da namorada do operador - de fato, um conjunto de iniciais, C.I.L, pode ter dado origem ao nome. Antes de tentar decifrar a Enigma pelo modo mais difícil, era rotina, entre os criptoanalistas, testar os cílios, e seus palpites às vezes davam resultado.

Os cílios não eram fraquezas da máquina Enigma, eles eram fraquezas do modo como a Enigma estava sendo usada. Erros humanos, nos mais altos níveis da cadeia de comando, também comprometiam a segurança das cifras. Os responsáveis pela produção dos livroscódigo tinham que decidir quais os misturadores que seriam usados a cada dia, e em quais posições. Eles tentavam garantir que as disposições dos misturadores fossem imprevisíveis, sem permitir que qualquer misturador ficasse na mesma posição por dois dias seguidos. Assim, se rotularmos os misturadores como 1, 2, 3, 4 e 5, então, no primeiro dia, poderíamos ter o arranjo 134 e no segundo dia o 215, mas não 214 porque o misturador número 4 não poderia ficar na mesma posição por dois dias seguidos. Isso pode parecer uma estratégia sensata, já que muda constantemente as posições dos misturadores, mas, na verdade, tal regra tornava a vida mais fácil para os criptoanalistas. Excluir certas sequências para evitar que um misturador ficasse na mesma posição significava que os criadores dos livros de códigos na verdade estavam reduzindo pela metade o número de arranjos possíveis. Os criptoanalistas de Bletchley perceberam o que estava acontecendo e exploraram ao máximo. Depois que identificavam a disposição dos misturadores para um determinado dia, eles imediatamente 
eliminavam metade das disposições para o dia seguinte. E assim, sua carga de trabalho era cortada pela metade.

De um modo semelhante, havia uma regra para a disposição dos fios no quadro de tomadas. Elas não podiam incluir nenhuma troca entre uma letra e sua vizinha, o que significava que $S$ poderia ser trocada por qualquer letra exceto $\mathrm{R}$ e $\mathrm{T}$. A teoria era de que tais trocas óbvias deviam ser evitadas deliberadamente, mas novamente a implementação de tal regra reduziu drasticamente o número de chaves possíveis.

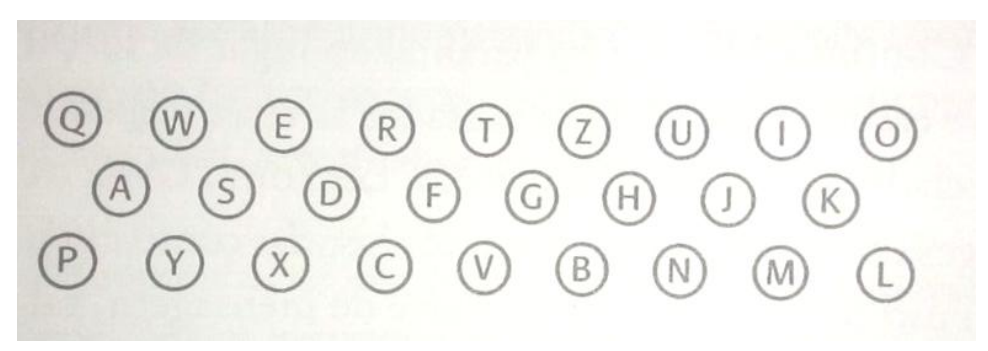

Figura 5: Layout do teclado Enigma

As buscas por novos atalhos criptoanalíticos era necessária porque a máquina Enigma continuou a evoluir ao longo da guerra. Os criptoanalistas eram continuamente forçados a inovar, a reprojetar e melhorar as bombas e a criar estratégias inteiramente novas. Parte do motivo para seu sucesso era a combinação bizarra de matemáticos, cientistas, linguistas, especialistas na cultura clássica, mestres do xadrez e viciados em palavras cruzadas dentro de cada casa. Um problema intratável era passado para a casa seguinte, até que chegasse a alguém com as ferramentas mentais certas para resolvê-lo, ou alguém que pudesse resolvê-lo parcialmente antes de passá-lo adiante. Gordon Welchman, que estava encarregado da Casa 6, descreveu sua equipe como "uma matilha de cães de caça tentando pegar o cheiro da presa". Houve muitos criptoanalistas notáveis e muitos avanços significativos, e precisaríamos de vários livros grossos para descrever em detalhes as contribuições de cada indivíduo. Entretanto, existe uma figura que deve ser destacada: foi Alan Turing quem identificou a maior fraqueza da Enigma e a explorou sem piedade. Graças a Turing tornou-se possível quebrar a cifra da Enigma mesmo sob as circunstâncias mais difíceis.

Alan Turin foi concebido no outono de 1911, em Chatrapur, uma cidade perto de Madras, ao sul da Índia, onde seu pai, Julius Turing, era um membro da administração civil indiana. Julius e sua esposa Ethel decidiram que seu filho deveria nascer na Grã-Bretanha, e voltaram para Londres, onde Alan nasceu no dia 23 de Junho de 1912. O pai voltou para a Índia logo depois e sua mãe o seguiu, 15 meses mais tarde, deixando Alan sob os cuidados de babás e amigas até que ele tivesse idade para entrar para o jardim de infância. 
Em 1926, aos 14 anos de idade, Turing tornou- se aluno da Escola Sherborne, em Dorset. O início de seu primeiro período escolar coincidiu com uma greve geral, mas Turing estava decidido a não faltar ao primeiro dia de aula. Assim, ele pedalou 100 quilômetros, sozinho em sua bicicleta, de Southampton até Sherborne, uma façanha que saiu no jornal local. Ao final do primeiro ano na escola ele ganhara a fama de ser um rapaz tímido e desajeitado, cujas únicas habilidades eram na área da ciência. O objetivo de Sherborne era transformar meninos em homens desenvolvidos, capazes de comandar o Império, mas Turing não partilhava desta ambição, e sua vida, como estudante, foi de maneira geral infeliz.

Seu único amigo verdadeiro em Sherborne era Christopher Morcom, que, como Turing, se interessava por ciência. Juntos eles debatiam as últimas descobertas e faziam suas próprias experiências. O relacionamento impulsionou a capacidade intelectual de Turing, mas também teve um profundo efeito emocional sobre ele. Andrew Hodges, biógrafo de Turing, escreve que "aquele foi seu primeiro amor... ele tinha aquele sentimento de entrega, aquela ampliação da consciência, como se uma cor brilhante explodisse sobre um mundo em preto e branco". A amizade durou quatro anos, mas Morcom parece não ter percebido os sentimentos profundos de Turing em relação a ele. Então, durante o último ano em Sherborne, Turing perdeu para sempre a chance de dizer o que sentia. Na quinta-feira, 13 de fevereiro de 1930, Christopher Morcom morreu subitamente de tuberculose.

Turing ficou arrasado com a perda da única pessoa que jamais amaria. E seu modo de enfrentar a morte de Morcom foi se entregar a seus estudos científicos, de modo a realizar o potencial do amigo. Morcom, que parecia ser o mais inteligente dos dois, já tinha conquistado uma bola na Universidade Cambridge. Turing julgou que era seu dever também conseguir um lugar em Cambridge e então fazer as descobertas que seu amigo teria feito se não morresse. Ele pediu à mãe de Christopher que lhe mandasse uma foto do filho e, quando ela chegou, Turing escreveu agradecendo: "Ela está na minha escrivaninha agora, para me encorajar em meu árduo trabalho".

Em 1931 ele foi admitido no King's College em Cambridge. Chegou durante um período de intensos debates sobre a natureza da matemática e da lógica e encontrou-se cercado por algumas das vozes mais importantes como Bertrand Russel, Alfred North, Whitehead e Ludwig Wittgenstein. No centro da discussão estava a questão da indecidibilidade, uma questão controvertida desenvolvida pelo lógico Kurt Godel. Sempre se presumira, pelo menos em teoria, que todas as questões da matemática poderiam ser respondidas. Contudo, Godel demonstrou que poderia haver uma minoria de questões que estariam além do alcance da prova lógica, as chamadas questões indecidíveis. Os matemáticas ficaram traumatizados 
com a notícia de que sua ciência não era a disciplina todo-poderosa que eles acreditavam ser. Tentaram salvá-la, procurando um meio de identificar as embaraçosas questões indecidíveis, de modo que pudessem separá-las de modo seguro Foi esse objetivo que mais tarde inspirou Turing a escrever seu trabalho científico mais influente, "Sobre os números computáveis", publicado em 1937. Na peça de Hugh Whitemore, Breaking the Code, sobre a vida de Turing, um personagem pergunta a Turing o significado de seu artigo. Ele responde. "É sobre o certo e o errado. Em termos gerais é um trabalho técnico sobre a lógica matemática, mas é também sobre a dificuldade em diferenciar o certo do errado. As pessoas pensam, a maioria das pessoas pensa, que na matemática nós sempre sabemos o que é certo e o que é errado. Não é assim. Não é mais assim".

Em sua tentativa de identificar as questões indecidíveis, o artigo de Turing descrevia uma máquina imaginária, projetada para executar uma operação matemática em especial, ou algoritmo. Em outras palavras, a máquina seria capaz de realizar uma série de etapas fixas, prescritas, que, por exemplo, resultariam na multiplicação de dois números. Turing imaginava que os números a serem multiplicados seriam introduzidos na máquina através de uma fita papel, como o papel perfurado usado para colocar uma melodia em uma pianola. E a resposta da multiplicação sairia em outra folha de papel. Turing imaginava toda uma série dessas máquinas de Turing, cada uma projetada para uma tarefa específica, tais como dividir, elevar ao quadrado ou fatorar. Então ele levou a ideia adiante de um modo mais radical.

Ele imaginou uma máquina cujo funcionamento interno pudesse ser alterado, de modo a fazêla executar todas funções de todas as máquinas de Turing concebíveis. As alterações seriam feitas inserindo-se fitas cuidadosamente selecionadas, que transformariam esta única máquina flexível em máquina de dividir, máquina de multiplicar ou em qualquer outro tipo de máquina. Turing chamou este engenho hipotético de máquina universal de Turing, porque ela poderia responder a qualquer questão que pudesse ser respondida pela lógica. Infelizmente, revelou-se não ser sempre possível, logicamente, responder a uma pergunta sobre a indecidibilidade de outra pergunta. E assim, mesmo uma máquina universal de Turing seria incapaz de identificar todas as questões indecidíveis.

Os matemáticos que leram o código de Turing ficaram desapontados pelo fato de o monstro de Godel não poder ser vencido, mas como prêmio de consolação, Turing lhes dera o esquema para a criação do moderno computador programável. Ele conhecia o trabalho de Babbage, e a máquina universal de Turing pode ser vista como uma reencarnação do Motor Diferencial $\mathrm{n}^{\circ} 2$. De fato, Turing fora além e fornecera uma sólida base teórica para a 
computação, dando ao computador um potencial até então não imaginado. Mas ainda era a década de 1930 e não existia tecnologia para transformar em realidade a máquina universal de Turing. Contudo, ele não ficou desanimado de que suas teorias estivessem além do que era tecnicamente possível. Meramente queria um reconhecimento da comunidade matemática, que de fato aplaudiu o seu trabalho como um dos avanços mais importantes do século. E Turing tinha apenas 26 anos.

Aquele foi um período particularmente feliz e bem-sucedido para ele. Durante a década de 1930, Turing ascendeu no mundo acadêmico até tornar-se membro do King's College, lar da elite intelectual do mundo. Levava uma vida típica de professor de Cambridge, misturando a matemática pura com atividades mais triviais. Em 1938 ele resolveu assistir ao desenho Branca de Neve e os Sete Anões, contendo a cena memorável em que a Bruxa Malvada mergulha uma maça no veneno. Depois disso os colegas ouviam Turing repetir, continuamente, a cantoria macabra, "Mergulhe a maça no caldo, e deixe a morte sonolenta penetrar".

Turing adorou seus anos em Cambridge. Além do sucesso acadêmico, encontrou-se num ambiente que o tolerava e apoiava. A homossexualidade era bem aceita na universidade, o que significava que ele estava libre para ter uma série de relacionamentos, sem ter que se preocupar com quem poderia descobrir ou o que os outros poderiam dizer. E embora não tivesse embarcado em nenhum relacionamento sério, de longo prazo, parecia estar satisfeito com sua vida. Então, em 1939, a carreira acadêmica de Turing foi interrompida abruptamente. A Escola de Cifras e Códigos do Governo o convidou para tornar-se criptonalista em Bletchley. No dia 4 de setembro de 1939, um dia depois de Neville Chamberlain declarar guerra contra a Alemanha, Turing se mudou da opulência do quadrilátero de Cambridge para hospedaria Crown Inn, em Shenley Brook End.

Todo o dia ele pedalava cinco quilômetros de Shenley Brook End até Bletchley Park, onde passava parte do tempo nas casas, contribuindo para o esforço rotineiro de quebra dos códigos, e parte do tempo na sala de pesquisas teóricas de Bletchley, que fora, anteriormente, um depósito de maças, peras e ameixas de Sir Herbert Leon. Era ali que os criptoanalistas pensavam e debatiam os novos problemas, ou tentavam se preparar para enfrentar problemas que poderiam surgir no futuro. Turing voltou suas atenções para o que aconteceria se os militares alemães mudassem o seu sistema de trocar chaves de mensagem. Os sucessos iniciais de Bletchley dependiam do trabalho de Rejewski, que explorara o fato de que os operadores da Enigma cifravam duas vezes cada chave de mensagem (por exemplo, se a chave de mensagem fosse YGB, o operador cifraria YGBYGB). Essa 
repetição deveria garantir que o operador não cometesse erros, mas criava uma falha na segurança da Enigma. Os criptoanalistas britânicos acreditavam que não demoraria muito para os alemães perceberem que a repetição da chave estava comprometendo sua cifra, e, quando isso acontecesse, os operadores receberia, ordens para abandonar a repetição, confundindo todas as técnicas de quebra de códigos usadas em Bletchley. Era o trabalho de Turing encontrar um modo alternativo para atacar a Enigma, uma abordagem que não dependesse da repetição da chave de mensagem.

Á medida que as semanas iam passando, Turing percebeu que Bletchley estava acumulando uma vasta biblioteca de mensagens decifradas e que muitas delas obedeciam a uma estrutura rígida. Estudando velhas mensagens decifradas, ele acreditava que podia, às vezes, prever parte do conteúdo de uma mensagem ainda não decifrada, baseando-se em quando ela fora enviada e de onde. Por exemplo, a experiência mostrava que os alemães enviavam relatórios cifrados sobre a previsão do tempo logo depois das seis horas da manhã de cada dia. Assim, uma mensagem cifrada interceptada as 6:05h, quase certamente conteria wetter, a palavra alemã para "tempo". O protocolo rigoroso, usando por qualquer organização militar, significava que tais mensagens eram altamente uniformes em seu estilo, de modo que Turing podia até mesmo ter confiança quanto à posição de wetter dentro da mensagem cifrada. Por exemplo, a experiência poderia indicar-lhe que as primeiras seis letras de um texto cifrado em particular correspondiam a wetter. E sempre que um pedaço de texto original pode ser associado com um pedaço do texto cifrado, essa combinação é conhecida como uma cola. Turing tinha certeza de que poderia usar as colas para decifrar a Enigma. Se ele tivesse um texto cifrado e conhecesse um trecho específico dele, digamos ETJWPX, representando wetter, seu desafio era identificar os ajustes da máquina Enigma que transformariam wetter em ETJWPX. O modo direto, mas não prático de fazer isso, seria o criptoanalista pegar uma máquina Enigma, datilografar wetter e ver se o texto cifrado correto saía dela. Se não saísse, o criptoanalista mudaria os ajustes da máquina, trocando os fios no quadro de tomadas, e trocando e reorientando os misturadores. Depois datilografaria wetter novamente. E se o texto cifrado correto não surgisse, ele mudaria os ajustes de novo, de novo e de novo. $\mathrm{O}$ único problema com essa abordagem, da tentativa e erro, era o fato de que existiam 159.000.000.000.000.000.000 de ajustes possíveis para verificar, de modo que achar aquele que transformava wetter em ETJWPX ainda era uma tarefa aparentemente impossível. 


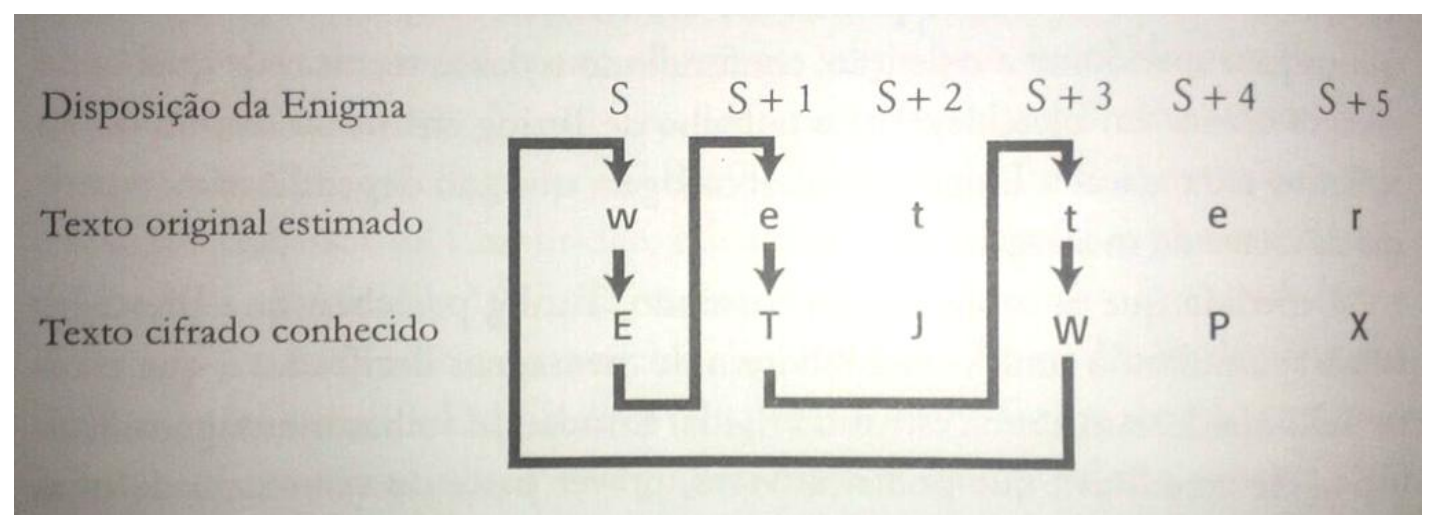

Figura 6: Umas das colas de Turing, mostrada aqui como um laço

Para simplificar o problema, Turing tentou seguir a estratégia de Rejewski de separar os ajustes. Ele queria divorciar o problema de encontrar o ajuste dos misturadores (Descobrir que misturador estava posicionado em que fenda, e quais seriam suas orientações respectivas) do problema de encontrar as ligações no quadro de tomadas. Por exemplo, se ele pudesse encontrar algo na cola que não tivesse relação nenhuma com a disposição dos fios, então tornar-se-ia razoável verificar cada uma das restantes 1.054.560 possíveis combinações dos misturadores (60 arranjos x 17.576 orientações). Tendo encontrado os ajustes corretos dos misturadores, ele poderia deduzir as ligações no quadro de tomadas. Posteriormente sua mente focalizou um tipo particular de cola que continha ligações internas, semelhantes às correntes exploradas por Rejewski. As correntes de Rejewski ligavam letras dentro da chave de mensagem repetida. Contudo, os elos de Turing não tinham nada a ver com a chave de mensagem, ele estava trabalhando com a possibilidade de que logo os alemães parariam de enviar chaves de mensagem repetidas. No lugar disso, os elos de Turing conectavam letras do texto original e do texto cifrado dentro de uma cola. Por exemplo, a cola mostrada na figura 6 contém um elo ou laço. Lembre0se de que as colas são apenas suposições, mas se presumirmos que a cola está correta, podemos ligar as letras $\mathrm{w}>\mathrm{E}, \mathrm{e}>\mathrm{T}, \mathrm{t}>\mathrm{W}$ como parte de um elo. Embora não saibamos nada sobre os ajustes da Enigma, podemos rotular o primeiro ajuste, seja ele qual for, como S. Nesse primeiro ajuste nós sabemos que w é cifrado como E. Depois da primeira cifragem, o primeiro misturador se mude de uma casa para a posição $S+1$, e a letra e é cifrada como T. O misturador avança outra casa e cifra uma letra que não está no elo, assim ignoramos esta cifragem. $\mathrm{O}$ misturador gira, avançando mais uma casa e novamente chegamos a uma letra que está no elo. No ajuste $\mathrm{S}+3$, sabemos que a letra té cifrada como W. Em resumo, nós sabemos que: 
No ajuste S, a Enigma cifra w como E

No ajuste $\mathrm{S}+1$, a Enigma cifra e como $\mathrm{T}$

No ajuste $\mathrm{S}+3$, a Enigma cifra t como W.

Até agora o elo parece ser nada mais do que um padrão curioso, mas Turing seguiu rigorosamente as implicações dos relacionamentos dentro do elo, e viu que eles davam-lhe o atalho drástico de que ele precisava para decifrar a Enigma. No lugar de trabalhar com apenas uma máquina Enigma para testar cada ajuste, Turing começou a imaginar três máquinas separadas, cada uma lidando com a cifragem de um elemento do elo. A primeira máquina tentaria cifrar w em E, a segunda tentaria cifrar e em T e a terceira t em W. As três máquinas teriam ajustes idênticos, exceto a segunda, que teria as orientações de seus misturadores deslocadas de uma casa em relação à primeira, este ajuste sendo rotulado como $\mathrm{S}+1$, e a terceira teria as orientações de seus misturadores deslocadas três casas adiante da primeira, este ajusto sendo classificado como $S+3$. Turing então imaginou um criptoanalista frenético mudando continuamente a posição dos cabos no quadro de tomadas, trocando os misturadores em suas fendas e mudando suas orientações de modo a chegar à cifragem correta. Os cabos que mudassem de posição na primeira máquina também mudariam de modo idêntico nas outras duas. Se a sequencia dos misturadores fosse mudada na primeira máquina, também o seria nas outras duas. E, o que seria crucial, qualquer que fosse a orientação dos misturadores na primeira máquina, a segunda teria a mesma orientação, só que deslocada de uma casa, enquanto a terceira teria a mesma orientação avançando três casas adiante.

Turing parece não ter conseguido muito. O criptoanalista ainda tem que verificar todos os 159.000.000.000.000.000.000 de disposições possíveis, e, para tornar as coisas piores, ele agora tem que fazê-lo, simultaneamente, em todas as três máquinas, no lugar de uma. Contudo, o passo seguinte na ideia de Turing transforma o desafio e o simplifica tremendamente. Ele imaginou ligar as três máquinas, conectando fios elétricos entre a entrada e saída de dados de cada máquina, como é mostrado na figura 7. De fato, o elo na cola é reproduzido pelo elo no circuito elétrico. Turing imaginou a máquina mudando suas disposições de cabos e misturadores, como foi descrito anteriormente, mas somente quando todos os ajustes estivessem corretos, para todas as três máquinas, é que o circuito se completaria, permitindo que a corrente fluísse entre todas as máquinas. Se Turing acrescentasse uma lâmpada ao circuito, a passagem da corrente faria com que ela se acendesse, sinalizando que o ajuste correto fora encontrado. Nesse ponto, todas as três 
máquinas ainda precisam verificar todas as 159.000.000.000.000.000.000 de disposições possíveis de modo a fazer a lâmpada se acender. Contudo, o que fizemos até agora foi meramente um preparativo para o salto lógico final de Turing. Aquele que simplificará a tarefa centenas de bilhões de vezes num único golpe.

Turing tinha montado o seu circuito elétrico de tal modo a anular o efeito do quadro de tomadas, de modo que pudesse ignorar os bilhões de ajustes possíveis na disposição dos fios. A figura 7 mostra que a corrente elétrica entrou na primeira Enigma, passou pelos misturadores e parou em alguma letra desconhecida que vamos chamar de L1. A corrente então flui através do quadro de tomadas, que transforma L1 em E. Essa letra E está conectada por um fio à letra e na segunda Enigma e, à medida que a corrente passa pelo segundo quadro de tomadas, ela é transformada de volta em L1. Em outras palavras, os dois quadros de tomadas se cancelam mutuamente. De modo semelhante, a corrente que sai dos misturadores da segunda Enigma entra no quadro de tomadas em L2 antes de ser transformada em $\mathrm{T}$. Essa letra $\mathrm{T}$ está ligada por um fio à letra $\mathrm{t}$ na terceira Enigma e, à medida que a corrente flui através do terceiro quadro de tomadas, ela é transformada novamente em L2. Resumindo, os quadros de tomadas se cancelam mutuamente ao longo do circuito inteiro, de modo que Turing podia ignorá-los completamente.

Turing só precisava ligar a saída do primeiro conjunto de misturadores, L1, diretamente na entrada do segundo conjunto de misturadores, também K1, e assim por diante. Infelizmente ele não conhecia o valor da letra L1, de modo que teria que conectar todas as 26 saídas do primeiro conjunto de misturadores a todas as 26 entradas correspondentes no segundo conjunto de misturadores, e assim por diante. De fato, agora teríamos 26 circuitos elétricos, e cada um contaria com uma lâmpada para sinalizar quando um circuito fosse completado. Os três conjuntos de misturadores então simplesmente verificariam cada uma das 17.576 orientações, com o segundo conjunto de misturadores sempre um passo à frente do primeiro, e o terceiro conjunto sempre dois passos adiante do segundo. Mais tarde, quando as orientações corretas dos misturadores fossem encontradas, um dos circuitos se completaria e uma lâmpada acenderia. Se os misturadores mudassem suas orientações a cada segundo, levaria apenas cinco horas para verificar todas as orientações.

Só restavam dois problemas: poderia acontecer de todas as três máquinas estarem funcionando com o arranjo errado de misturadores, porque as máquinas Enigma funcionavam com três misturadores escolhidos ao acaso entre um conjunto de cinco, colocados em qualquer ordem, o que resulta em 60 arranjos possíveis. Daí que, se todas 
17.576 orientações forem verificadas, e a lâmpada não tiver se acendido, será necessário tentar outro dos 60 arranjos possíveis e continuar tentando até que o circuito se complete.

Ou o criptoanalista poderia ter sessenta conjuntos de três Enigmas funcionando em paralelo. O segundo problema envolve encontrar a disposição dos fios no quadro de tomadas depois que as orientações e o arranjo dos misturadores são descobertos. Isto é relativamente simples. Usando uma máquina Enigma com o arranjo e as orientações corretas dos misturadores, o criptoanalista datilografa o texto cifrado e olha para o texto original que sai do outro lado. Se o resultado for tewwer no lugar de wetter, então fica claro que os fios do quadro de tomadas devem ser inseridos de modo a trocar as letras w e t. E se datilografarmos outros trechos do texto cifrado veremos outras disposições dos fios serem reveladas.

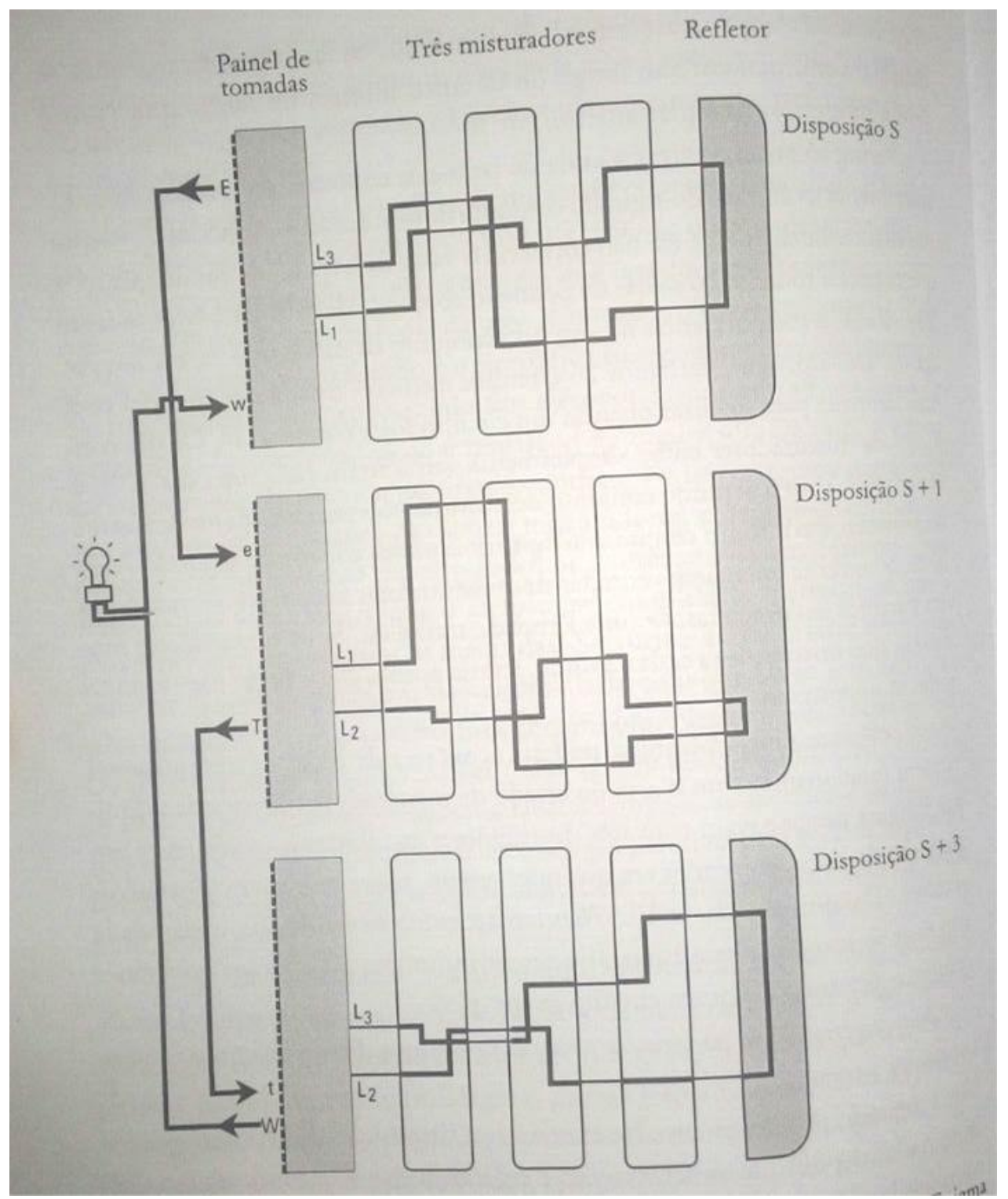

Figura 7: o laço na cola pode estar paralelo com o laço elétrico. Três máquinas Enigmas são dispostas de forma idêntica, exceto pelo fato de a segunda máquina ter seu misturador movido uma posição para frente (disposição $S+1$ ), e o terceiro ter seu misturador movido duas posições para frente (disposição 
$\mathrm{S}+3$ ). A saída de cada Enigma é conectada à entrada da seguinte. Os misturadores giram em harmonia até que o circuito é completado e as luzes se acendem. No diagrama acima, o circuito está completo, correspondendo a disposição correta.

A combinação de colas, elos e máquinas conectadas eletricamente resultou num feito extraordinário de criptoanálise, e somente Turing, com seu conhecimento único em máquinas matemáticas, poderia tê-lo conseguido. Suas meditações sobre máquinas imaginárias de Turing destinavam-se a responder a questões exotéricas sobre a indecidibilidade matemática, mas esta pesquisa, puramente acadêmica, lhe deu as ferramentas mentais certas para projetar uma máquina prática, capaz de resolver problemas muito reais.

Bletchley foi capaz de obter cem mil libras para transformar a ideia de Turing em engenhos funcionais, que receberam o nome de bombas, porque sua abordagem mecânica tinha uma semelhança passageira com a bomba de Rejewski. Cada uma das bombas de Turing consistia em doze conjuntos de misturadores Enigma conectados eletricamente e assim era capaz de lidar com elos muito mais longos de letras. A unidade completa teria dois metros de altura, por dois de comprimento e um metro de largura. Turing finalizou o projeto no início de 1940, e o trabalho de construção foi entregue à fábrica British Tabulating Machinery, em Letchworth.

Enquanto esperava a entrega das bombas, Turing continuou seu trabalho diário em Bletchley. As notícias do grande avanço logo se espalharam entre os outros criptoanalistas veteranos, que reconheceram Turing como um decifrador de códigos com um dom singular. De acordo com Peter Hilton, colega de Turing em Bletchley, "Alan Turing era obviamente um gênio, mas era um gênio amistoso, fácil de abordar. Ele sempre tinha tempo e boa vontade para explicar suas ideias, e não era um especialista limitado, seus pensamentos percorriam uma vasta gama das ciências exatas."

Entretanto, tudo o que se referia à Escola de Códigos e Cifras do Governo era altamente secreto, de modo que ninguém, fora de Bletchley Park, sabia da extraordinária realização de Turing. Por exemplo, seus pais não tinha ideia de que Alan fosse um decifrador de códigos, muito menos o principal criptoanalista britânico. Ele uma vez contou a sua mãe que estava envolvido em algum tipo de pesquisa militar, mas não entrou em detalhes. Ela ficou desapontada de que isso não tivesse resultado num corte de cabelo mais respeitável para seu filho. Embora Bletchley fosse dirigido pelos militares, eles tinham decidido tolerar o cabelo comprido e as excentricidades daqueles professores. Turing raramente se barbeava, suas unhas estavam cheias de sujeira e as roupas amarrotadas. Contudo, se os militares teriam 
tolerado sua homossexualidade é algo que permanece desconhecido. Jack Good, um veterano de Bletchley comentou: "Felizmente as autoridades não sabiam que Turing era homossexual. De outro modo, poderíamos ter perdido a guerra."

O protótipo da primeira bomba, batizada de Victory, chegou em Bletchley no dia 14 de março de 1940. A máquina entrou em operação imediatamente, mas os resultados iniciais não foram muito satisfatórios. A máquina revelou-se mais lenta do que se esperava, levando uma semana para encontrar uma chave em particular. Houve um esforço concentrado para aumentar a eficiência da bomba e um projeto modificado foi apresentado, algumas semanas depois. Levaria mais quatro meses para construir a bomba aperfeiçoada. E enquanto isso os criptoanalistas teriam que enfrentar a calamidade que tinham previsto. Em 10 de maio de 1940 os alemães mudaram o protocolo de troca de chaves. Eles não mais repetiam a chave de mensagem e daí em diante o número de decifragens bem-sucedidas da Enigma caiu drasticamente. O blecaute nas informações durou até 8 de agosto, quando a nova bomba chegou. Batizada de Agnus Dei, e apelidada Agner, esta máquina correspondeu às expectativas de Turing.

Em dezoito meses havia mais quinze bombas em operação, explorando as colas, verificando os ajustes dos misturadores, revelando chaves, cada uma estalando como um milhão de agulhas de tricô. Se tudo estava correndo bem, uma bomba podia encontrar uma chave da Enigma em uma hora. E depois que a disposição dos fios no quadro de tomadas e o ajuste dos misturadores (a chave de mensagem) foram estabelecidos para uma mensagem em especial, era fácil deduzir a chave daquele dia. E todas as mensagens enviadas naquele mesmo dia poderiam ser decifradas.

Embora as bombas representassem um avanço vital na criptoanálise, a decifragem não se tornara uma mera formalidade. Havia muitas barreiras a serem vencidas antes que as bombas pudessem começar a procurar uma chave. Por exemplo, para operar uma bomba primeiro precisava-se encontrar uma cola. Os decifradores mais experientes dariam as colas para os operadores das bombas, mas não havia garantia de que tivessem deduzido o significado correto do texto cifrado. E mesmo que tivessem a cola certa, ela poderia estar no lugar errado - os criptoanalistas poderiam ter suposto que uma mensagem cifrada continha uma certa frase, mas associado esta frase ao trecho errado do texto cifrado. Contudo, havia um truque bem hábil para verificar se a cola estava na posição correta.

$\mathrm{Na}$ cola seguinte, o criptoanalista está confiante em que o texto original está correto, mas ele não tem certeza se corresponde ao trecho correto de texto cifrado 
Texto original estimado: wetternullsechs

Texto cifrado conhecido: IPRENLWKMJJSXCPLEJWQ

Mas uma das características da Enigma era uma incapacidade de cifrar uma letra como ela mesma, o que é uma consequência do refletor. A letra a nunca poderia ser cifrada como A, a letra $b$ nunca seria cifrada como B, e assim por diante. A cola acima deve portanto estar desalinhada porque o primeiro e em wetter corresponde a uma E no texto cifrado. Para encontrar o alinhamento correto, nós simplesmente fazemos o texto original e o texto cifrado deslizarem, um ao longo do outro, até que nenhuma letra corresponda ao seu equivalente. Se deslizarmos o texto original uma casa para esquerda, a correspondência ainda falha porque, desta vez, o primeiro s em sechs corresponde a um $\mathrm{S}$ no texto cifrado. Contudo, se deslocarmos o texto original uma casa para a direita, não ocorrem cifragens proibidas. Esta cola, portanto, deve estar na posição correta e pode ser usada como base para uma decifragem pela bomba:

Texto original estimado: wetternullsechs

Texto cifrado conhecido: IPRENLWKMJJSXCPLEJWQ

As informações obtidas em Bletchley era passadas apenas às mais altas patentes militares e a membros selecionados do gabinete de guerra. Winston Churchill tinha plena consciência da importância das decifragens em Bletchley e visitou os quebradores de códigos no dia 6 de setembro de 1941. Ao encontrar-se com alguns dos criptoanalistas, ficou surpreso com a mistura bizarra de gente que lhe fornecia informações tão valiosas. Além dos matemáticos e dos linguistas, havia uma autoridade em porcelana, um curador do Museu de Praga, o campeão de xadrez da Grã-Bretranha e numerosos especialistas no jogo de bridge. Churchill murmurou para Sir Stewart Menzies, chefe do Serviço de Informações Secretar: "Eu lhe disse para apelar para tudo, mas não esperava que seguisse minhas ordens tão literalmente". Mas, apesar do comentário, ele tinha um grande afeto por aquela equipe heterogênea, chamando-os de "os gansos que botavam ovos de ouro e jamais grasnam."

A visita destinava-se a aumentar o moral dos decifradores de códigos, mostrando-lhes que seu trabalho era apreciado nos mais altos escalões. Mas também teve o efeito de dar a Turing e seus colegas a confiança para abordar Churchill quando a crise surgiu. Para aproveitar ao máximo as bombas, Turing precisava de uma equipe maior, mas seus pedidos eram 
bloqueados pelo comandante Edward Travis, que assumira o cargo de diretor de Bletchley, e achava não ter justificativas para recrutar mais gente. No dia 21 de outubro de 1941 os criptoanalistas agiram de modo insubordinado, ignorando Travis e escrevendo diretamente para Churchill.

\section{Caro primeiro-ministro}

Há algumas semanas o senhor nos deu a honra de sua visita e acreditamos que considera importante o nosso trabalho. Deve ter visto que, graças em boa parte à energia e à perspicácia do comandante Travis, estamos bem equipados com as "bombas" para quebrar os códigos Enigma da Alemanha. Achamos, entretanto, que o senhor deveria saber que este trabalho está sendo atrasado, e, em alguns casos, nem é feito, principalmente porque não temos gente suficiente para lidar com ele. Nossa razão para lhe escrever diretamente é que há meses estamos fazendo tudo o que é possível através dos canais normais, e achamos que a situação não vai melhorar sem sua intervenção...

Somos seus servos mais leais
A.M. Turing
W.G. Welchman
C.H.O'D. Alexander
P.S.Milner-Barry

Churchill não hesitou em responder. Passou imediatamente um memorando para seu principal assistente:

\section{AGIR PRONTAMENTE}

Certifique-se de que eles tenham tudo o que pedem, em caráter de extrema prioridade, e me informe quando estiver sido feito.

Daí em diante não houve mais obstáculos para recrutar pessoal ou obter materiais. No final de 1942 havia 49 bombas e uma nova estação de bombas foi inaugurada em Gayhurst Manor, logo ao norte de Bletchley. Como parte da estratégia de recrutamento, a Escola de Cifras e Códigos do Governo publicou uma carta no Daily Telegraph. Ela fazia um desafio anônimo 
aos leitores, perguntando se alguém seria capaz de resolver as palavras cruzadas do jornal em menos de 12 minutos. Acreditava-se que especialistas em palavras cruzadas também seriam bons quebradores de códigos, completando as mentes cientificas que já estavam em Bletchley - mas é claro, nada disso era mencionado no jornal. Os 25 leitores que responderam ao desafio foram convidados para fazer um teste de palavras cruzadas na rua Fleet. Cinco deles completaram as palavras cruzadas no tempo exigido e outro só deixou de completar uma palavra ao final dos 12 minutos. Algumas semanas depois, todos os seis foram entrevistados pelo serviço militar de informações e recrutados como decifradores de códigos em Bletchley Park.

\section{Roubando Livros de Código}

Até aqui, neste capítulo, o tráfego de mensagens pela Enigma foi tratado como se fosse um gigantesco sistema de comunicações, mas na realidade havia várias redes distintas. $\mathrm{O}$ Exército alemão no Norte da África, por exemplo, tinha a sua própria rede separada e seus operadores das Enigmas recebiam livros de códigos diferentes dos usados na Europa. Assim, se Bletchley tivesse sucesso em identificar uma chave diária usada no Norte da África, ele seria capaz de decifrar todas as mensagens que os alemães enviassem para o Norte da África naquele dia, mas a chave não teria utilidade para decifrar as mensagens sendo transmitidas na Europa. De modo semelhante, a Luftwaffe tinha a sua própria rede de comunicações, e, para decifrar o tráfego de mensagens para a Luftwaffe, Bletchley teria que decifrar a chave diária da Luftwaffe.

Algumas redes eram mais difíceis de decifrar do que outras. A Kriegsmarine era a mais difícil de todas, porque a Marinha alemã usava uma versão mais sofisticada da máquina Enigma. Por exemplo, os operadores da Enigma naval podiam escolher entre oito misturadores, no lugar de cinco, o que significava que eles tinham um número quase seis vezes maior de arranjos de misturadores, o que resultava em seis vezes mais chaves para serem verificadas em Bletchley. A outra diferença na Enigma naval se relacionava com o refletor, responsável por mandar o sinal elétrico de volta pelos misturadores. Na Enigma padrão o refletor ficava sempre fixo, em uma orientação específica, mas na Enigma naval o refletor poderia ser fixado em 26 orientações diferentes. Daí que o número de chaves possíveis aumentava por um fator de 26.

A criptoanálise da Enigma naval tornava-se ainda mais difícil porque os operadores da Marinha eram muito cuidadosos em não mandar mensagens padronizadas, assim privando 
Bletchley de suas colas. E, além disso, a Kriegsmarine também instituíra um sistema mais seguro para selecionar e transmitir chaves de mensagem.

Misturadores extras, um refletor variável e mensagens não padronizadas junto com um novo sistema de troca de chaves de mensagens, se uniam para tornar as comunicações navais alemãs impenetráveis.

O fracasso de Bletchley em decifrar a Enigma naval significava que a Kriegsmarine começava a levar vantagem na Batalha do Atlântico. O almirante Karl Donitz tinha desenvolvido uma estratégia em duas etapas altamente eficiente para a guerra naval. Ela começava com os submarinos se espalhando e percorrendo o Atlântico em busca dos comboios aliados. Assim que um deles localizava um alvo, iniciava o passo seguinte de chamar os outros submarinos para o local. O ataque só começava quando uma grande matilha de submarinos fora reunida (os alemães chamavam seus submarinos de "lobos do mar", daí o termo matilha ou alcateia para designar um grupo). Para que essa estratégia de ataque coordenado tivesse sucesso, era essencial que a Kriegsmarine possuísse comunicações seguras. A Enigma naval fornecia esse tipo de comunicações e os ataques dos submarinos tiveram um impacto devastador sobre o transporte marítimo aliado, que fornecia à Grã-Bretanha a comida e os armamentos de que ela tanto necessitava.

E enquanto as comunicações com os submarinos permanecessem secretas, os aliados não teriam ideia da localização dos submarinos, não podendo traçar rotas seguras para os comboios. Parecia que a única estratégia do Almirantado para determinar a localização dos submarinos era marcar os locais onde os navios britânicos tinham afundado. Entre junho de 1940 e junho de 1941, os aliados perderam uma média de 50 navios por mês, e corriam o risco de não ser capazes de construir novos navios em tempo hábil para substituir as perdas. E além da destruição intolerável de navios, também havia um custo humano terrível - 50 mil marinheiros aliados morreram durante a guerra. A menos que as perdas pudessem ser reduzidas drasticamente, os britânicos corriam o risco de perder a Batalho do Atlântico, o que significaria perder a guerra. Churchill escreveria mais tarde: "No meio daquela torrente de acontecimentos violentos pairava uma ansiedade suprema. Batalhas podiam ser perdidas ou ganhas, empreendimentos podiam ter sucesso ou fracassar, territórios seriam conquistados ou abandonados, mas o que dominava a nossa capacidade de continuar a guerra, ou mesmo de nos mantermos vivos, era o nosso domínio das rotas oceânicas e o livre acesso aos nossos portos".

A experiência polonesa e o caso de Hans-Thilo Schmidt ensinaram à equipe de Bletchley Park que, se uma empreitada intelectual não consegue quebrar uma cifra, então é necessário 
confiar na espionagem, no roubo e na infiltração para obter as chaves inimigas. Ocasionalmente Bletchley conseguiria um avanço contra a Enigma naval graças a um plano engenhoso da RAF. Os aviões britânicos lançavam minas sobre um local escolhido, obrigando os navios alemães a enviar mensagens de aviso para as outras embarcações. Essas advertências, cifradas pela Enigma, conteriam inevitavelmente um mapa de referência, mas o que era crucial, este mapa com a localização das minas já seriam conhecido pelos britânicos, de modo que poderia ser usado como cola. Em outras palavras, Bletchley sabia que um trecho em especial do texto cifrado representava um determinado conjunto de coordenadas. Semear minas para obter colas era conhecido como "jardinagem", mas exigia que a RAF voasse em missões especiais, de modo que não podia ser feito regularmente. Bletchley tinha que encontrar outra maneira de quebrar o código da Enigma naval.

Uma estratégia alternativa dependia do roubo de chaves. Um dos planos mais ousados para roubar chaves da Enigma foi bolado por Ian Fleming, o criador de James Bond, que foi membro do Serviço Secreto Naval durante a guerra. Ele sugeriu que um bombardeiro alemão capturado fizesse um pouco se emergência no Canal da Mancha, perto de um navio alemão. Os marinheiros alemães se aproximariam do avião para resgatar seus companheiros. A tripulação do bombardeiro, aviadores ingleses fingindo ser alemães, entraria no navio e capturaria seus livros de código. Esses livros de código alemães continham a informação necessária para estabelecer a chave de cifragem, e como os navios passavam longos períodos longe de suas bases, os livros de códigos seriam válidos para pelo menos um mês. Capturando esses livros, a equipe de Bletchley seria capaz de decifrar a Enigma naval durante um mês inteiro.

Depois de aprovar o plano de Fleming, conhecido como Operação Impiedosa, o Serviço Secreto britânico começou a preparar um bombardeiro Heinkel para um pouco forçado no mar e reuniu uma tripulação de ingleses que falavam alemão. A data marcada foi o início do mês, de modo a capturar um livro-código novo. Fleming foi para Dover, de modo a supervisionar a operação, mas infelizmente não havia tráfego de barcos alemães naquela área, de modo que o plano foi adiado indefinidamente. Quatro dias depois, Frank Birch, que dirigia o departamento naval de Bletchley, registrou a reação de Turing e de seu colega Peter Twinn: "Turing e Twinn me procuraram como agentes funerários que tivessem perdido um bom defunto há dois dias, e fumegaram com o cancelamento da Operação Impiedosa".

Mais tarde a operação foi cancelada, mas livros-código alemães acabaram sendo capturados durante uma série de ataques ousados contra navios meteorológicos e submarinos. Esses "furtos", como eram chamados, deram a Bletchley os documentos necessários para acabar 
com o blecaute de informações. Com a Enigma naval transparente, Bletchley podia determinar a localização dos submarinos e a Batalha do Atlântico começou a mudar em favor dos aliados. Os comboios podiam ser guiados para longe dos submarinos e os contratorpedeiros britânicos podiam até mesmo passar para a ofensiva, procurando e afundando os submarinos.

Era vital que o Alto Comando alemão nunca suspeitasse de que os aliados tinham furtado os livros de códigos das Enigmas. Se os alemães descobrissem que sua segurança fora penetrada, eles reforçariam as Enigmas e Bletchley estaria de volta ao ponto de partida. Como no caso do telegrama Zimmermann, os britânicos tomaram várias precauções para evitar despertar suspeitas, tais como afundar a embarcação alemã depois de roubar seus livros de códigos. Isso faria o almirante Donitz acreditar que o material cifrado fora para o fundo do oceano e não caíra em mãos aliadas.

Depois que o material secreto era capturado, era preciso tomar oturas precauções antes de explorar o resultado das informações. Por exemplo, as decifragens da Enigma davam a localização de vários submarinos, mas seria tolice atacar todos eles, porque um aumento súbito e inexplicado nas vitórias britânicas alertaria os alemães de que suas comunicações estavam sendo decifradas. Consequentemente, os aliados permitiam que alguns submarinos escapassem, e só atavam os outros depois que um avião de observação era enviado, para justificar a aproximação do contratorpedeiro algumas horas depois. Como alternativa, os aliados podiam enviar mensagens falsas, descrevendo avistamentos de submarinos que forneceriam explicações suficientes para o ataque.

Apesar desta política, para minimizar os indícios de que a Enigma fora decifrada, as ações dos britânicos às vezes provocavam suspeitas entre os especialistas da segurança alemã. Em certa ocasião Bletchley decifrou uma mensagem da Enigma dando a localização exata de um grupo de petroleiros e navios de suprimentos alemães, num total de nove. O Almirantado decidiu não afundar todos os navio, já que uma varredura completa dos alvos levantaria suspeitas entre os alemães. Eles informaram aos contratorpedeiros a localização exata de apenas sete navios, o que deveria permitir que o Gadania e o Gonzenheim escapassem ilesos. Os sete navios escolhidos foram realmente afundados, mas os destróieres da Marinha Real acidentalmente encontraram os dois navios que deveriam ser poupados, e os afundaram também. As tripulações dos contratorpedeiros não sabiam nada sobre a Enigma ou a política de não levantar suspeitas - apenas acreditavam estar cumprindo com seu dever. Em Berlim, o almirante Kurt Fricke resolveu investigar este e outros ataques semelhantes, explorando a possibilidade de que os britânicos tivessem decifrado a Enigma. O relatório concluiu que as 
numerosas perdas eram, ou o resultado natural do mar ou eram provocadas por um espião britânico infiltrado na Kriegsmarine. A quebra da Enigma era considerada impossível e inconcebível. 


\section{O ESCARAVELHO DE OURO}

(EDGAR ALLAN POE)

Oh! Oh! Este rapaz está dançando com louco!

Foi picado pela tarântula!

Tudo às avessas

HÁ MUITOS anos passados, travei amizade com um cavalheiro chamado William Legrand. Pertencia ele a uma antiga família huguenote e fora, outrora, rico, mas uma série de infortúnios tinham-no reduzido à miséria. Para evitar as mortificações que se seguiram a seus desastres, deixou Nova Orleans, terra natal de seus avós, e passou a residir na ilha de Sullivan, perto de Charleston, na Carolina do Sul.

Esta ilha é bastante singular. E formada quase que só de areia e tem cerca de três milhas de comprimento. Sua largura em ponto algum excede de um quarto de milha. Está separada do continente por um braço de mar quase imperceptível que se insinua através de uma vastidão de mangues e lodo, refúgio favorito das aves aquáticas. A vegetação, como se pode supor, é escassa, ou, pelo menos, raquítica. Nenhuma árvore de grande porte ali se vê. Perto da extremidade ocidental, onde se ergue o Forte Moultrie e onde se encontram alguns miseráveis barracões, habitados, durante o verão, pelos que fogem da poeira e da febre de Charleston, pode ser encontrada, a cerdosa palmeira-anã. Mas toda a ilha, com exceção dessa ponta ocidental e de uma faixa de áspera e branca praia na costa marítima, está coberta de densa capoeira de murta cheirosa, tão apreciada pelos horticultores ingleses.

Os arbustos atingem ali, às vezes, à altura de quinze a vinte pés e formam um matagal quase impenetrável, impregnando o ar com sua fragrância.No mais recôndito recesso desse matagal, não longe da ponta ocidental e mais remota da ilha, Legrand construiu uma pequena cabana, em que residia, quando, pela primeira vez, por mero acaso, travei conhecimento com ele.

Esse conhecimento logo amadureceu em amizade, pois naquele solitário muito havia para excitar interesse e estima. Achei-o bem-educado, dotado de incomuns faculdades espirituais, infectadas, apenas, de misantropia e sujeitas a caprichosas disposições de entusiasmo e de 
melancolia alternadas. Tinha consigo muitos livros, mas raramente se servia deles. Suas principais diversões eram a caça e a pesca, além de vaguear por entre as murtas à busca de conchas ou espécimes entomológicos. Sua coleção destes últimos podia ser invejada por um Swammerdam. Nessas excursões era acompanhado, habitualmente, por um negro velho, chamado Júpiter, que tinha sido libertado antes dos reveses da família mas não pudera ser levado, por ameaças ou promessas, a abandonar o que considerava seu direito de acompanhar os passos de seu jovem "sinhô Will". Não é improvável que os parentes de Legrand, considerando-o de intelecto um tanto desarranjado, tenham tentado instilar essa teimosia em Júpiter, tendo em vista a vigilância e a guarda do erradio.

Os invernos, na latitude da ilha de Sullivan, raramente são muito severos e no fim do ano é coisa rara, na verdade, ser necessário acender. Pelo meado de outubro de $18 \ldots$, houve, porém, um dia de sensível friagem. Justamente antes do pôr do sol, rompi, através dos arbustos sempre verdes, até a cabana de meu amigo, a quem eu não tinha visitado havia várias semanas, residente, como então era, em Charleston, a uma distância de nove milhas da ilha, num tempo em que as facilidades de travessia e volta estavam muito abaixo dos dias atuais.

Depois de alcançar a cabana, bati à porta, segundo meu costume, e, não obtendo resposta, procurei a chave no lugar onde eu sabia que ela ficava escondida, girei-a na fechadura e entrei. Belo fogo ardia na lareira. Era uma novidade, e de modo algum desagradável. Tirei o sobretudo e, puxando uma poltrona para junto das achas crepitantes, esperei pacientemente a chegada dos donos da casa. Pouco depois de escurecer, chegaram eles e me deram cordiais boas vindas. Júpiter, arreganhando os dentes de uma orelha a outra, apressou-se em preparar algumas aves aquáticas para o jantar. Legrand estava num de seus acessos - como poderia eu denominá-los diversamente? - de entusiasmo. Encontrara uma concha bivalva desconhecida, formando novo gênero, e, mais do que isso, caçara e apanhara, com o auxílio de Júpiter, um scarabaeus, que acreditava, ser totalmente novo, mas a respeito do qual desejava conhecer minha opinião, no dia seguinte.

E por que não esta noite? - perguntei, esfregando as mãos por cima do fogo e desejando que toda a raça dos scarabaei fosse para o inferno.

Ah! Se eu tivesse sabido que você estava aqui! - disse Legrand. - Mas faz tanto tempo que não o vejo; e como podia eu prever que você viria visitar-me logo nesta noite, grande entre todas? Ao vir para casa, encontrei-me com o Tenente $\mathrm{G}^{* * *}$, do forte, e, muito doidamente, emprestei-lhe o escaravelho; de modo que, para você, é impossível 
vê-lo antes que amanheça. Fique aqui esta noite e mandarei Júpiter descer, ao nascer do sol. É a mais bela da criação!

O quê? O nascer do sol?

Ora... não! O escaravelho. É de uma brilhante cor de ouro, mais ou menos do tamanho de uma noz grande, com duas manchas negras de azeviche, perto de uma das extremidades das costas e uma outra, um pouco mais comprida, na outra extremidade. As antenas são...

Não tem nada de estanho nele não, sinhô Will, tou apostando - interrompeu aí Júpiter. - O escarvéio é um escaravéio de oro maciço, cada pedacinho dele, por dentro e tudo, menos as asa. Eu nunca vi um escarvéio nem a metade mais pesado, em toda a minha vida.

Bem, suponhamos que é, Jup - replicou Legrand, algo mais vivamente, pareceu-me, do que o caso requeria. - É isso algum motivo para você deixar as aves queimarem? A cor - e aí ele voltou-se para mim - é realmente quase capaz de afiançar a opinião de Júpiter. Você nunca viu um brilho metálico mais cintilante do que o emitido pela casca dele. Mas sobre isso você poderá julgar amanhã. Até lá, vou dar-lhe alguma idéia do formato.

Dizendo isso, sentou-se a uma mesinha em que havia pena e tinta, porém não papel. Procurou alguma folha numa gaveta, mais não encontrou.

- Não faz mal - disse, por fim. - Isto servirá.

E tirou do bolso do colete um pedaço do que eu tomei por um gorro muito sujo e fez nele, com a pena, rápido desenho. Enquanto o fazia, conservei-me na cadeira junto ao fogo, pois estava ainda com frio. Quando o desenho ficou pronto, ele mo entregou, sem levantar-se. No momento em que eu o recebia, ouviu-se um alto grunhido, seguido de arranhões na porta. Júpiter abriu-a e um grande cão terra-nova, que pertencia a Legrand, entrou correndo, pulou sobre meus ombros e cumulou-me de festas, pois eu lhe dedicara muita atenção em visitas anteriores. Quando suas brincadeiras terminaram, olhei para o papel e, para falar verdade, fiquei um pouco intrigado com o que meu amigo desenhara. 
- Bem! - disse eu, depois de contemplá-lo por alguns minutos.

- Esse é um estranho scarabaeus, devo confessá-lo; para mim, é novo; nunca vi coisa alguma como ele, antes, a não ser um crânio, ou uma caveira, com o que ele se parece mais do que qualquer coisa que já esteve sob a minha observação.

- Uma caveira! - repetiu Legrand. - Oh! Sim! bem... ele tem algo dessa aparência, no papel, sem dúvida. As duas manchas pretas do alto assemelham-se aos olhos, hein? E a mais comprida, embaixo, assemelha-se à boca... Depois, a forma doconjunto é oval.

- Talvez seja isso - disse eu -, mas, Legrand, receio que você não seja artista. Devo esperar até ver o próprio bicho, se quiser formar uma idéia de sua aparência pessoal.

- Bem, não sei... - disse ele, um pouco irritado. - Eu desenho toleravelmente; pelo menos, deveria desenhar; tive bons professores e orgulho-me de não ser um imbecil.

- Mas, meu caro, então você está brincando - falei. - Isto é um crânio bem passável... de fato posso dizer que é um crânio excelente, de acordo com as noções vulgares sobre tais espécimes de fisiologia. E seu scarabaeus deve ser o mais esquisito do mundo, se se parecer com isto. Ora, poderíamos extrair uma impressionante superstição desse esboço. Presumo que você chamará o escaravelho scarabaeus caput hominis, ou qualquer coisa desse gênero. Há muitos títulos semelhantes na História Natural. Mas onde estão as antenas de que você falou?

- As antenas! - disse Legrand, que parecia estar-se tornando inexplicavelmente furioso com o assunto. - Estou certo de que você deve ver as antenas! Fi-las tão nítidas como são no inseto original e julgo que é suficiente. 
- Bem... bem... talvez você tenha feito - disse eu. - Contudo não as vejo.E passei-lhe o papel, sem observação adicional, não desejando-lhe o temperamento. Mas muito surpreendido estava com a reviravolta que as coisas sofreram; seu mau-humor me intrigava. E, quanto ao desenho do bicho, positivamente nenhuma antena era visível e o conjunto possuía uma semelhança muito estreita com os desenhos comuns de uma caveira.

Ele recebeu o papel, muito impaciente, e estava a ponto de amarfanhá-lo, aparentemente para atirá-lo ao fogo, quando uma olhadela casual ao desenho pareceu de súbito prender-lhe a atenção. Num instante seu rosto enrubesceu com violência, e noutro ficou excessivamente pálido. Durante alguns minutos continuou a pesquisar o desenho, acuradamente, do lugar onde se sentava. Afinal levantou-se, apanhou uma vela na mesa e foi sentar-se sobre uma arca de viagem, no canto mais distante do aposento. Ali, de novo, procedeu a um exame ansioso do papel, virando-os em todas as direções. Nada disse, todavia, e essa conduta grandemente me assombrou; achei prudente, porém, não exacerbar o crescente mau humor de seu temperamento com qualquer comentário.

Depois ele tirou do bolso do colete uma carteira, colocou o papel dentro dela, cuidadosamente, e depositou-a numa escrivaninha, que fechou a chave.

Tornou-se, então, mais comedido em seus modos mas o aspecto primitivo de entusiasmo desaparecera por inteiro. Contudo, não parecia tão de mau-humor quanto abstraído. À medida que a noite avançava, ele se tornava cada vez mais perdido em sonhos, dos quais não o podia despertar qualquer de minhas observações. Fora minha intenção passar a noite na cabana, como antes freqüentemente fizera, mas, vendo naquela disposição de ânimo o dono da casa, considerei mais prudente despedir-me. Ele não insistiu para que eu ficasse, mas, quando parti, apertou-me a mão com cordialidade além da costumeira.

Foi cerca de um mês depois disso (e durante esse intervalo eu nada soubera de Legrand) que recebi, em Charleston, a visita de seu criado, Júpiter. Eu nunca vira o bom negro velho com aparência tão assustada e temi que algum sério desastre tivesse sobrevindo a meu amigo.

- Bem, Jup - falei -, que há agora? Como vai seu patrão?

- Ora, pra falá verdade, sinhô, ele num vai tão bem cumo devia sê. 
- Não vai bem? Sinto muito em saber disso. De que é que ele se queixa?

- Tá-i. É isso! Ele num queixa de nada... mas ele está muito doente, muito mesmo.

- Muito doente, Júpiter? Por que você não disse isso logo? Ele está de cama?

- Num tá, não! Ele num acha lugá nenhum aão! Aí éque a porca torce o rabo! Tou cum a cabeça tonta por causa do sinhô Will!

- Júpiter, eu gostaria de entender o que você está dizendo. Você falou que seu patrão está doente. Ele não lhe contou de que é que sofre?

- Ora, sinhô, é bobage ficá quebrano a cabeça cum esse negócio! O sinhô Will num fala nada, diz que num tem coisa nenhuma... mas, então, por que é que ele fica pra lá e prá ca, oiano pra onde anda, cum a cabeça pra baixo e os ombro pra cima? E por que é que ele fica o tempo todo com uns numos, e...

- Com o quê, Júpiter?

- Fazendo uns numos e figuras na pedra, as figuras mais esquisitas que eu já vi. Eu já tou ficano cum medo, palavra. Tenho de ficá cum os óio pregado em riba dele só. Trodia, ele me escapuliu antes do só nascê e ficou sumido todo o santo dia. Eu tinha cortado uma boa vara, pra dá um bom ezempre nele quando ele vortasse, mas eu tô tão bobo que num tenho coração pra fazê ....... Ele tava com uma cara tão triste!

- Hein? Como? Ah, sim!. . . Afinal de contas, eu acho que você fez melhor em não ser tão severo com o coitado. Não bata nele Júpiter. Ele pode muito bem não agüentar isso. Mas você não faz uma idéia do que é que causou essa doença, ou antes, essa mudança de procedimento? Aconteceu alguma coisa desagradável desde que eu estive lá? 
- Não sinhô. Num teve nada desagradave desde esse dia. Foi antes disso, eu acho. Foi mesmo no dia que o sinhô teve lá.

- Como? Que é que você quer dizer?

- Ora, sinhô, eu quero dizê o escarvéio, tá-i!

- O quê?

-O escarvéio. Tou com toda a certeza de que sinhô Will foi mordido, lá por perto da cabeça, por aquele escarvéio de ouro.

- E que motivo você tem para essa suposição, Júpiter?

- Ele tem puã que chega, sinhô, e boca também. Eu nunca vi escaravéio tão encapetado. Ele bate e morde em tudo o que chegá perto . Sinhô Will apanhô ele primeiro, mas teve de deixá ele i embora depressa outra vez, tou-lhe falando... Foi nessa ocasião que ele deve tê dado a mordida. Eu num gosto do jeito da boca do escaravéio, de modo nenhum. Assim, eu num ia pegá nele cum meus dedo, mas agarrei ele cum pedaço de papé, que eu achei. Enrolei ele no papé e enfiei um pedaço na boca dele. Foi assim que eu fiz.

- E você pensa, então, que seu patrão foi picado pelo bicho e que a picada é que o fez ficar doente?

- Eu num penso, nada. Eu sei. O que é que faz ele ficá variano por causa de ouro, se num é a mordida do escarvéio de ouro? Eu já ouvi falá desses escarvéio de ouro antes disso.

- Mas como é que você sabe que ele sonha com ouro?

- Cumo é que eu sei? Ora, porque ele fala disso enquanto tá dormindo. Tá-i como é que eu sei.

- Bem, Jup, talvez você tenha razão. Mas a que afortunada circunstância devo atribuir a honra de sua visita, hoje? 
- Que é que é isso, sinhô?

- Você traz algum recado do Sr. Legrand?

- Não, sinhô. Eu trago é esta carta.

E aí Júpiter me entregou um bilhete, que rezava assim:

Meu caro:

Por que não o tenho visto, há tanto tempo? Espero que você não tenha caído na infantilidade de ofender-se com qualquer pequena rudeza de minha parte; mas, não; isso é improvável.

Desde que o vi, tenho tido grandes motivos de ansiedade. Tenho algo a dizer-lhe e, contudo, mal sei como falar, nem se devo falar.

Não tenho andado muito bem, nestes últimos dias, e o pobre velho Júpiter me irrita quase além do suportável com suas significativas atenções. Você acreditará que ele preparou uma pesada vara, no outro dia, para castigar-me, por ter escapulido dele e passado o dia, sozinho, entre as colinas do continente?

Acredito, deveras, que só minha aparência doentia me salvou de uma surra...Não fiz qualquer acréscimo à minha coleção, desde que nos encontramos.

Se você puder, de qualquer modo, fazê-lo sem inconveniente, venha com Júpiter. Venha.

Desejo vê-lo, esta noite. É assunto de importância. Asseguro-lhe que é da mais alta importância.

Sempre seu,

William Legrand 
Havia algo no tom desse bilhete que me causou grande incomodo. Todo o seu estilo diferia completamente do de Legrand. Com que poderia estar ele sonhando? Que nova excentricidade dominava seu cérebro excitável? Que "negócio da mais alta importância" podia ele, possivelmente, ter a realizar? O que Jupiter me dissera dele não afiançava nada de bom. Eu temia que a contínua pressão da má sorte, afinal, tivesse inteiramente desarranjado a razão de meu amigo. Sem um momento de hesitação, por conseguinte, preparei-me para acompanhar o negro.

Ao chegar ao cais, notei uma foice e três pás, todas aparentemente novas, no fundo do bote em que devíamos embarcar.

- Que quer dizer isso tudo, Jup? interroguei.

- Foice, sinhô, e pá.

- Muito bem; mas que é que elas estão fazendo aí?

- É a foice e as pá que sinhô Will falô pra eu comprá prá ele na cidade e foi o diabo o dinheirão que eu tive de dá por elas.

- Mas, por tudo quanto é misterioso, que é que seu " Sinho Will" vai fazer com foices e pás?

- Tá-i uma coisa que eu num sei e um raio me parta se eu num aquerdito que ele também num sabe. Mas isso tudo é coisa do escarvéio.

Verificando que nada de satisfatório podia obter de Júpiter, cuja mente parecia estar inteiramente absorvida pelo "escarvéio", entrei no bote e soltei a vela. Com bela e forte brisa, logo corremos para a pequena angra, ao norte do Forte Moultrie, e uma caminhada de cerca de duas milhas levou-nos à cabana. Eram quase três horas da tarde quando chegamos. Legrand estivera a esperar-nos com ansiosa expectativa. Apertou-me a mão, com um aperto nervoso, que me alarmou e fortaleceu as suspeitas já entretidas. Seu rosto é pálido até a lividez e seus olhos, fundos, brilhavam com um clarão anormal. Depois do algumas perguntas, relativas à sua saúde, interroguei-o, não sabendo que coisa melhor dizer, sobre se recebera do Tenente $\mathrm{G}^{* * *}$ o scarabaeus. 
- Oh, sim! replicou ele, corando violentamente. - Recebi-o dele, na manhã seguinte. Nada me podia tentar a separar-me desse scarabaeus. Você sabe que Júpiter tem toda a razão acerca dele?

- De que modo? - perguntei, com triste pressentimento no coração.

- Ao supor que ele é um escaravelho de ouro autêntico.

Falou isso com aspecto de profunda seriedade e senti-me indizivelmente perturbado.

- Esse escaravelho vai fazer minha fortuna - continuou ele, com sorriso triunfante.

- Vai reinstalar-me na posse do que era de minha família. É qualquer coisa de admirar, então, que eu o aprecie que eu o aprecie tanto? Desde que a Fortuna achou conveniente concedermo, só tenho que usá-lo de modo adequado e chegarei até o ouro de que ele é o indício. Júpiter, traga-me aquele scarabaeus!

- O quê? O escarvéio, sinhô? Eu acho mió num tê trabaio com aquele escaravéio... O sinhô mesmo apanhe ele.

Ai Legrand levantou-se, com ar grave e imponente, e trouxe-me o bicho, tirando-o de uma caixa de vidro em que ele estava encerrado. Era um belo scarabaeus, de tipo naquele tempo desconhecido para os naturalistas e naturalmente de grande valor do ponto de vista científico. Havia duas manchas negras e redondas, perto de uma das extremidades das costas, e outra comprida mancha perto da outra extremidade. A casca era enormemente dura e brilhante, com toda a aparência de ouro brunido. $\mathrm{O}$ peso do inseto era bem digno de nota e, tomando tudo isso em consideração, eu mal poderia censurar Júpiter por sua opinião relativamente a ele; mas, por minha vida, não podia dizer que fazer, quanto à concordância de Legrand com essa opinião.

- Mandei buscá-lo - disse ele, num tom grandiloqüente -, mandei buscá-lo para poder ter seu conselho e auxílio, a fim de favorecer os desígnios da Sorte e do escaravelho. 
- Meu caro Legrand - gritei eu, interrompendo-o -, você com certeza não está bem e faria melhor se tomasse algumas pequenas precauções . Deve ir para a cama e eu ficarei com você alguns dias até que recobre a saúde. Você está com febre e...

- Tome meu pulso - disse ele.

Tomei-lhe o pulso e, para falar a verdade, não achei o mais leve indício de febre.

- Mas você pode estar doente e, contudo, não ter febre. Permita-me que, desta vez, me faça de médico para você. Em primeiro lugar, vá para a cama. Em segundo lugar...

- Você está enganado - interrompeu ele. - Sinto-me tão bem quanto seria de esperar no estado de excitação em que me encontro. Se você realmente se interessa pela minha saúde, trate de aliviar-me dessa excitação.

- E como se há de fazer?

- Muito facilmente. Júpiter e eu vamos fazer uma expedição às colinas, no continente, e nessa expedição necessitamos do auxílio de alguma pessoa em quem possamos confiar.

Você é a única que nos merece essa confiança. Se formos bem sucedidos ou fracassarmos, a excitação que você agora percebe em mim será, igualmente, aliviada.

- Tenho o maior desejo em servi-lo, de qualquer maneira - respondi -, mas...pretende você dizer que esse infernal escaravelho tem alguma relação com sua expedição às colinas?

- Tem.

- Então, Legrand, não posso tomar parte numa empresa tão absurda.

- Sinto muito... sinto muito... pois teremos de tentá-la nós mesmos.

- Pois tentem-na vocês! Este homem está seguramente maluco! Mas, vejamos! Quanto tempo se propõe você ficar ausente? 
- Provavelmente a noite inteira. Partiremos agora mesmo e estaremos de volta, de qualquer modo, ao amanhecer.

- E você me promete, sob palavra de honra, que, quando tiver passado esse capricho de vocês e o negócio do escaravelho (bom Deus!) estiver resolvido, para satisfação sua, voltará então para casa e seguirá estritamente meu conselho, como se fosse o seu médico?

- Sim, prometo. E agora, partamos, pois não temos tempo perder.

De coração opresso, acompanhei meu amigo. Pusemo-nos a caminho, cerca das quatro horas, Legrand, Júpiter, o cachorro, e Jupiter tinha consigo a foice e as pás, pois insistira em carregar todas, mais por medo, pareceu-me, de deixar qualquer daqueles utensílios ao alcance de seu patrão do que por qualquer excesso de solicitude ou complacência. Sua fisionomia estava extremamente carrancuda e "esse mardito escarvéio" foram as únicas palavras que escaparam de seus lábios durante o trajeto. Pela minha parte, estava encarregado de um par de lanternas furta-fogo, enquanto Legrand contentava-se com o scarabaeus, que levava amarrado à ponta de um pedaço de barbante fazendo-o girar, para lá e para cá, com o ar de um prestidigitador, enquanto caminhava. Ao observar esta última e plena prova da aberração mental de meu amigo, mal podia eu reter as lágrimas.

Pensei, porém, que seria melhor satisfazer-lhe a fantasia, pelo menos um momento, ou até que eu pudesse adotar medidas mais enérgicas, com probabilidade de êxito. Entrementes, tentei, mas completamente em vão, sondá-lo a respeito do objetivo da caminhada. Tendo conseguido induzir-me a acompanhá-lo, não parecia desejar travar conversa sobre qualquer assunto da menor importância. E a todas as minhas perguntas não se dignava dar outra resposta senão: "Veremos!"

Cruzamos o braço de mar na ponta da ilha por meio de um esquife e, subindo os terrenos altos da praia do continente, continuamos na direção noroeste, através de um trecho de terras expressivamente agrestes e desoladas, onde não se via vestígio algum de passo humano. Legrand seguia na dianteira, com decisão, parando apenas um instante aqui e ali para consultar o que parecia ser certos marcos, por ele mesmo colocados em ocasião anterior. 
Caminhamos, assim, cerca de duas horas, e o sol estava a ponto de pôr-se, quando penetramos numa região infinitamente mais sinistra do que qualquer outra até então vista. Era uma espécie de tabuleiro, perto do cume de uma colina quase inacessível, densamente coberta da base ao cimo e entremeada de imensos penhascos que pareciam estar soltos sobre o solo e, em muitos casos, só não se precipitavam nos vales, lá embaixo, graças ao suporte dos troncos contra os quais se reclinavam. Profundas ravinas, em várias direções, davam ao cenário um ar de solenidade ainda mais severo.

A plataforma natural sobre a qual havíamos garimpado estava espessamente coberta de sarças, através das quais logo descobrimos que seria impossível abrir caminho, a não ser por meio da foice e Júpiter, por ordem de seu patrão, começou a rasgar para nós uma estrada, até o pé de um tulipeiro gigantesco, que se erguia, com uns oito ou dez carvalhos, sobre o planalto, e os ultrapassava, a todos, bastante, bem como a todas as outras árvores que até então eu vira, pela beleza da folhagem e da forma, pela vasta circunferência dos ramos e pela majestade geral de seu aspecto. ao alcançarmos essa árvore, Legrand voltou-se para Júpiter e perguntou-lhe se achava que podia subir por ela. $\mathrm{O}$ velho pareceu um tanto aturdido com essa pergunta e, durante alguns instantes, não deu resposta. Afinal, aproximou-se do imenso tronco, andou devagar em torno dele e examinou-o com minuciosa atenção. Terminado o exame disse simplesmente:

- Sim, sinhô. Jup sobe em quarqué arve que ele nunca não viu na sua vida.

- Então suba, o mais depressa possível, pois em breve estará demasiado escuro para ver o que devemos fazer.

- Até aonde eu tenho de assubi, sinhô? - perguntou Júpiter.

- Suba primeiro pelo tronco principal e depois eu lhe direi que caminho deverá tomar. .

Ah! Espere! Leve este escaravelho com você.

- O escarvéio, sinhô Will? O escarvéio de ouro? - gritou o negro, recuando de medo. - Pur que é que eu tenho de levar o escarvéio pra cima da arve? Que eu me dane se fizé isso! 
- Se você tem medo, Jup, um negralhão como você, de pegar num pequeno escaravelho morto e inofensivo, pode levá-lo por este barbante. Mas se, de qualquer modo, não quiser levá-lo consigo lá para cima, serei forçado a quebrar sua cabeça com esta pá.

- Que negócio é esse, sinhô? - disse Júpiter, evidentemente envergonhado, a ponto de se tornar mais condescendente. Sempre quereno armá baruio com o nego véio... Eu tava só brincano! Eu, tê medo de escarvéio? Nem tou ligando pra ele!

Aí pegou com precaução a extremidade do barbante e, mantendo o inseto tão longe de sua pessoa quanto as circunstâncias lhe permitiam, preparou-se para subir à árvore.

Quando novo, o tulipeiro, ou Liriodendron tulipiferum, o mais majestoso dos habitantes da floresta americana, tem um tronco caracteristicamente liso e muitas vezes se eleva a grande alturas sem ramos laterais; mas, chegando à maturidade, a casca torna-se rugosa e desigual, enquanto muitos galhos pequenos aparecem sobre o tronco. Assim, a dificuldade da ascensão, no caso presente, era mais aparente que real. Abraçando o enorme cilindro o mais estreitamente possível, com os braços e os joelhos, agarrando com mãos alguns dos brotos e descansando os dedos nus sobre outros, Júpiter, depois de ter escapado de cair uma ou duas vezes, por fim içou-se até à primeira grande forquilha, parecendo considerar a coisa toda como virtualmente executada. Na realidade, o risco da empresa havia passado, embora o negro estivesse a sessenta ou setenta pés do solo.

- Pra donde devo i agora, sinhô Will? - perguntou ele.

- Vá subindo pelo galho mais grosso, o daquele lado - disse Legrand.O negro obedeceu-lhe prontamente e, ao que parece, sem muita dificuldade, subindo cada vez mais alto, até que não se conseguia vislumbrar seu vulto agachado, através da densa folhagem que o tocava. Nesse momento, ouviu-se sua voz, numa espécie de grito.

- Até onde eu tenho de assubi ainda?

- A que altura você está? - perguntou Legrand.

- Tão arto, tão arto - replicou o negro - que tou podendo vê o céu pelo arto da arve. 
- Não se preocupe com o céu, mas preste atenção ao que eu digo. Olhe para o tronco embaixo e conte os galhos abaixo de você, desse lado. Quantos galhos você passou?

- Um, dois, treis, quatro, cinco. . . Passei cinco gaios grandes desse lado sinhô.

- Então, suba um galho mais alto.Em poucos minutos ouviu-se novamente a voz, anunciando que galho fora atingido.

- Agora, Jup - gritou Legrand, evidentemente bastante excitado. - Quero que você vá andando por esse galho, até onde puder. Se vir qualquer coisa estranha, diga-me.

Desta vez, qualquer pequena dúvida que eu pudesse ainda entreter a respeito da insanidade de meu pobre amigo foi, por fim, desfeita. Não tinha outra alternativa senão concluir que ele estava atacado de loucura e fiquei seriamente ansioso por fazê-lo voltar à casa. Enquanto ponderava sobre o que seria melhor, ouviu-se de novo a voz de Júpiter.

- Tou com muito medo de me arriscá nesse gaio mais longe. Ela tá quage todo podre.

- Você está dizendo que é um galho podre, Júpiter? - gritou Legrand, com voz trêmula.

- Nhô, sim. Tá podre que nem uma tranca véia. Podrinho da Sirva. Não tá prestano mais pra nada.

- Em nome do céu, que devo fazer? - perguntou Legrand, demonstrando o maior desespero.

- Que fazer? - disse eu, alegre por encontrar uma oportunidade de intercalar uma palavra. Ora, ir para casa e deitar-se.

- Vamos embora! Não seja teimoso! Está ficando tarde, e além disso não deve esquecer-se de sua promessa.

- Júpiter! - gritou ele, sem me dar nenhuma atenção. - Está me ouvindo? 
- Nhô, sim, sinhô Will, tou escuitando o sinhô muito bem.

- Experimente, então, o galho com seu canivete e veja se está muito podre.

- Ele tá podre, sinhô, e muito mesmo - replicou o negro, em poucos momentos. Mas num tá tão podre como devia tá. Eu sozinho, posso me arriscá mais um bocado pelo gaio.

- Você sozinho? Que é que você quer dizer?

- Ora, tou falano do escarvéio. Ele é muito pesado. Se eu soltasse ele primeiro, então o gaio não ia se quebrá, só com o peso de um nego.

- Velhaco dos infernos! - gritou Legrand, aparentemente muito aliviado. - Que é que você está pensando para falar uma asneira dessas? Se você soltar esse escaravelho, palavra que lhe quebro o pescoço. Escute aqui Júpiter. Você está-me ouvindo?

- Tou sim, sinhô. Num é preciso gritá pro pobre nego desse jeito.

- Bem, então escute! Se você se arriscar pelo galho, até onde puder chegar sem perigo, e não soltar o escaravelho, eu lhe darei um dólar de prata de presente logo que você descer.

- Tou ino, sinhô Will.. . Tá feito - replicou o negro, bem depressa. Tou agora quage na pontinha!

- Na ponta! gritou satisfeito Legrand. - Você diz que está na ponta desse galho?

- Tou chegando no fim, sinhô... ooooooooooooh! Vala-me Deus! Que é isso aqui em cima da arve?

- Bem! - gritou Legrand, altamente satisfeito. - Que é? Uai! Pra mim isso é uma caveira! Arguém deixô a cabeça dele aqui em riba da arve e os corvo comero tudo quanto era pedaço de carne.

- Uma caveira, foi o que você disse? Muito bem!... Como é que ela está presa no 
galho? Que é que a segura?

- Sei não, sinhô. Vô espiá. Tá-i, palavra que é uma coisa muito esquisita... Tem um prego enorme na caveira, pregando ela na arve.

- Bem. Agora, Júpiter, faça exatamente como eu vou dizer

- Sim, sinhô.

- Preste atenção, então. Procure o olho esquerdo da caveira

- Humm! Humm! Tá bem! Mas ela num tem ôio esquerdo nenhum!

- Maldita estupidez! Você não sabe distinguir sua mão direita da esquerda?

- Sei. Isso eu sei... Sei muito bem... é com a mão esquerda; que eu racho a lenha.

- Muito bem. Você é canhoto. E seu olho esquerdo está do mesmo lado de sua mão esquerda. Acho que agora você já sabe achar o olho esquerdo da caveira ou o lugar onde ele estava. Achou?

Houve um prolongado intervalo. Por fim o negro falou:

- O ôio esquerdo da caveira tá também do mesmo lado da mão esquerda dela? E purque a caveira não tem nem um pedacinho de mão nenhuma... Num faz mal! Achei o ôio esquerdo agora . Tá aqui o ôio esquerdo. Que é que eu vô fazê cum ele?

- Deixe o escaravelho cair por dentro dele, até onde o barbante der mas tenha cuidado e não largue o barbante.

- Tá tudo pronto, sinhô Will. Foi muito fácil pô o escarvéio no buraco. Óia ele lá embaixo!

Durante essa conversa, nenhuma parte do corpo de Júpiter podia ser vista; mas o escaravelho, que ele fizera descer, era agora visível na ponta do cordel e cintilava, como um globo de ouro 
brunido, aos últimos raios do sol poente, alguns dos quais ainda iluminavam debilmente o cume sobre que nos achávamos. O scarabaeus pendia inteiramente livre de quaisquer galhos e, se deixado cair, tombaria aos nossos pés.

Legrand imediatamente tomou da foice e limpou com um espaço circular, de três ou quatro jardas de diâmetro, bem por baixo do inseto. E, tendo feito isso, ordenou a Júpiter que e soltasse o barbante e descesse da árvore.

Fincando uma cunha, com grande cuidado, no lugar preciso em que o escaravelho caiu, meu amigo tirou então do bolso uma fita métrica. Amarrando uma ponta da mesma ao ponto da árvore que estava mais próxima da cunha, desenrolou-a até alcançar a cunha e tornou a desenrolá-la, na direção já estabelecida pelos dois pontos da cunha e da árvore, pela distância de cinqüenta pés. Júpiter ia limpando as sarças com a foice. No lugar assim atingido, foi cravada segunda cavilha e em volta desta, como centro, traçou ele um círculo grosseiro, de cerca de quatro pés de diâmetro. Apanhando então uma pá e dando uma a Júpiter e a outra a mim, Legrand pediu-nos que cavássemos tão depressa quanto possível.

Para falar verdade, eu nunca tive predileção por tal divertimento, em tempo algum, e naquele momento particular de boa-vontade teria recusado, pois a noite ia chegando e me achava muito fatigado com o exercício já feito. Mas não vi jeito de escapar e temia eu turbar a serenidade de meu pobre amigo com uma recusa. Se eu, de fato, pudesse confiar na ajuda de Júpiter, não teria hesitado em tentar carregar o lunático para casa, à força; mas conhecia demasiado bem a disposição de ânimo do velho negro para crer que ele me ajudaria, sob quaisquer circunstâncias, numa disputa pessoal com seu patrão.

Não tinha dúvida de que este último era vítima de alguma das inúmeras superstições meridionais acerca de ouro enterrado e de que tal fantasia recebera confirmação pela descoberta do scarabaeus, ou, talvez, pela obstinação de Júpiter em asseverar que era "um escarvéio de ouro de verdade". Um espírito disposto à loucura seria facilmente conduzido por semelhantes sugestões, especialmente se as mesmas se harmonizassem com idéias favoráveis e preconcebidas. Recordei-me, então, da conversa do coitado acerca de ser o escaravelho "o indício de sua fortuna". Por causa de tudo isso eu me sentia tristemente aborrecido e incomodado, mas afinal resolvi fazer do mal um bem e cavar com boa-vontade, para que 
assim o visionário se convencesse mais cedo, pela demonstração de seus olhos, da inutilidade das opiniões que entretinha.

Acesas as lanternas, entregamo-nos ao trabalho com um zelo digno de causa mais tradicional; e ao cair o clarão sobre nossas pessoas e objetos, não pude deixar de pensar no grupo pitoresco que compúnhamos e quão estranhas e suspeitas nossas ações deveriam parecer a qualquer intruso que, por acaso, pudesse surgir onde nos achávamos.

Cavamos bem firmemente, durante duas horas. Pouca coisa se disse. E nosso embaraço principal estava nos latidos do cachorro, que tomava especial interesse em nossa tarefa. Afinal, ele se tornou tão impertinente que tivemos receio de que desse o alarme algum desgarrado que andasse nas vizinhanças. Ou, antes, esse era o temor de Legrand, pois eu me sentiria alegre com qualquer interrupção que me permitisse levar o alucinado para casa. $\mathrm{O}$ barulho, por fim foi muito eficazmente silenciado por Júpiter, que, saindo do buraco com um ar carrancudo de resolução, amarrou a cabeça do bicho com um de seus suspensórios e depois voltou, com um risinho sério à sua tarefa.

Quando o tempo mencionado expirara, alcançáramos uma profundidade de cinco pés e, contudo, nenhum sinal de qualquer tesouro se manifestara. Seguiu-se uma pausa geral e comecei a esperar que a farsa estivesse no fim. Legrand, contudo, embora evidentemente muito desapontado, enxugou a testa, pensativo, e recomeçou. Caváramos todo o círculo de quatro pés de diâmetro e agora, pouco a pouco, alargávamos o limite, chegando a cavar mais de dois pés de profundidade.

Nada apareceu, todavia. O procurador de ouro, de quem eu sinceramente me apiedava, pulou afinal do buraco, com mais amargo desaponto impresso em todos os traços do rosto, pôs-se, vagarosa e relutantemente, a vestir o paletó que atirara fora ao começar o serviço. Entrementes, eu não fiz qualquer observação.

Júpiter, a um sinal do patrão, começou a juntar as ferramentas.Feito isso e desamordaçado o cachorro, voltamos para casa, em profundo silêncio.Déramos, talvez, doze passos nessa direção, quando, com um alto palavrão, Legrand saltou sobre Júpiter e agarrou-o pelo pescoço. O negro, atônito, abriu os olhos e a boca até onde foi possível soltou as pás e caiu de joelhos. 
- Vagabundo! - disse Legrand, sibilando as sílabas, por entre dentes cerrados. - Negro dos diabos! Fale, estou-lhe dizendo! Responda-me neste instante, sem querer enganar-me! Qual é... qual é seu olho esquerdo?

- Oh, meu Deus! Sinhô Will! Então num é este aqui meu ôio, esquerdo? - grunhiu o terrificado Júpiter, colocando a mão sob o órgão direito da visão e conservando-a ali, com desesperada pertinácia, como se temesse uma tentativa imediata de seu patrão para arrancá-lo.

- Bem eu pensei! Eu sabia disso! Viva! - vociferou Legran soltando o negro e executando uma série de piruetas e cambalhotas, para grande espanto do criado, que, erguendo-se de

sobre os joelhos, olhava, mudo, de seu patrão para mim e de mim para seu patrão.

- Venham! Precisamos voltar! - disse este último. - A partida não foi perdida ainda.E de novo caminhou para o tulipeiro.

- Júpiter, - disse ele, - quando o acompanhamos. - Venha cá! A caveira estava pregada ao galho com a face para fora ou com a face para o ramo?

- A cara tava pra fora, sinhô, e assim os corvo pudero chegá bem nos óio, sem trabáio nenhum.

- Bem. Então foi por este olho ou por aquele que você deixou cair o escaravelho? - e aí Legrand apontou para cada um dos olhos de Júpiter.

- Foi por este ôio, sinhô... O ôio esquerdo... certinho como o sinhô me disse - e aí era o olho direito o que o negro indicava.

- Pois vamos! Devemos tentá-lo de novo.

Aí meu amigo, em cuja loucura agora eu via, ou imaginava ver, alguns indícios de método, removeu a cavilha que marcava o lugar onde o escaravelho caiu para um lugar cerca de três polegadas para oeste de sua primitiva posição. Tomando, depois, a fita métrica do ponto mais 
próximo do tronco até a cavilha, como antes, e continuando a estendê-la em linha reta até a distância de cinquienta pés, foi indicado um lugar afastado várias jardas do ponto em que tínhamos estado cavando.

Em torno da nova posição, um círculo, um tanto maior do que no caso anterior, foi agora traçado e nós de novo pusemo-nos a trabalhar com a pá. Eu estava terrivelmente cansado; mas, mal compreendendo o que havia causado a mudança em meus pensamentos, não sentia mais nenhuma grande aversão pelo trabalho imposto. Tinha-me tornado mais inexplicavelmente interessado, e não só, até mesmo excitado. Talvez houvesse algo, em meio de todas as atitudes extravagantes de Legrand, certo ar de previsão, ou de decisão, me impressionava.

Cavei com afinco e, de vez em quando, me surpreendia realmente aguardando, com algo que muito se assemelhava à expectativa, o imaginado tesouro, cuja visão havia dementado meu infeliz companheiro. Ao tempo em que tais devaneios de pensamento maiormente se apoderaram de mim e quando já estávamos a trabalhar talvez uma hora e meia, fomos de novo interrompidos pelos violentos latidos do cão. Sua inquietação, no primeiro caso, tinha sido, evidentemente, apenas o resultado de brincadeira, capricho; mas agora assumia um tom mais amargo e sério. À nova tentativa de Júpiter para amordaçá-lo, ele ofereceu furiosa resistência e, pulando para dentro do buraco, começou a cavar a terra freneticamente, com as patas. Em poucos segundos, tinha descoberto um monte de ossos humanos, formando dois esqueletos completos, entremeados de vários botões de metal e do que parecia ser poeira de lã apodrecida. Uma das pazadas puseram a descobrir a lamina de uma faca espanhola e, ao cavarmos mais fundo, três ou quatro moedas de ouro e de prata vieram a lume.

À vista delas, a alegria de Júpiter mal pôde ser contida, mas a fisionomia de seu patrão apresentava um ar de extremo desaponto. Insistiu conosco, porém, a que continuássemos nossos esforços e mal as palavras acabavam de ser pronunciadas, eu cambaleei para a frente, tendo enfiado a ponta de minha bota num anel de ferro que jazia semi-enterrado na terra solta.

Trabalhávamos, agora, com verdadeira ânsia e nunca passei minutos de mais intensa excitação. Durante este intervalo, havíamos completamente desenterrado uma arca oblonga, de madeira que, pela sua perfeita conservação e maravilhosa resistência, evidenciava plenamente ter sido sujeita a algum processo de mineralização, talvez o do bicloreto de 
mercúrio. Esta caixa tinha três pés e meio de comprimento, três pés de largura e dois e meio de altura. Estava firmemente fechada por aros de ferro fundido, com ferros formando uma espécie de grade em volta da arca. De cada lado da caixa, perto da tampa, havia três anéis de ferro, seis ao todo, por meio dos quais seis pessoas poderiam agarrá-la com firmeza. Reunidos os nossos maiores esforços, mal pudemos afastar o cofre um pouquinho no seu leito. Percebemos imediatamente a impossibilidade de levantar tão grande peso. Felizmente, as únicas trancas da tampa consistiam em dois ferrolhos corrediços, que puxamos para trás, tremendo e vacilando de ansiedade.

No mesmo instante, tivemos ali, cintilando diante de nossos olhos, um tesouro de incalculável valor. Como os raios de luz das lanternas caíssem dentro do poço, deste subiam, irradiando, uma incandescência e um resplendor provindos dum confuso montão de ouro e de jóias, que nos deslumbravam completamente a vista.

Não pretenderei descrever os sentimentos que de mim se apossaram ao contemplar aquilo. Predominava, sem dúvida, o espanto. Legrand parecia exausto e dizia muito poucas palavras. A fisionomia de Júpiter apresentou, por alguns minutos, a palidez mortal que é possível, na ordem natural das coisas, um rosto de negro exibir. Parecia estupefato, siderado. Logo em seguida ajoelhado dentro do buraco e, mergulhando os braços, nus ate os cotovelos, no ouro, ali deixou-os ficar, como se gozasse a volúpia dum banho. Por fim, com um profundo suspiro, exclamou, se falasse sozinho:

- E tudo isso vem do escarvéio de ouro! Do bunito escaravéio de ouro! O coitado do escarveinho de ouro que eu tanto descompus, chamei tanto nome feio! Ocê num tem vergonha disso não seu nego? Vamos, me arresponda!

Tornou-se necessário, por fim, que eu despertasse tanto o patrão como o criado, chamandolhes a atenção para a urgência de remover o tesouro. Estava ficando tarde, e era conveniente que desenvolvêssemos certa atividade para ter tudo aquilo em casa antes do amanhecer. Difícil foi combinarmos o que deveríamos fazer, e muito tempo perdemos a decidir-nos, tão confusas eram as idéias de todos nós. Finalmente, aliviamos o peso da caixa, removendo dois terços de seu conteúdo, e só então fomos capazes, com algum esforço de tirá-lo do buraco. 
Os objetos retirados foram depositados entre as sarças, ficando o cachorro a guardá-los, com estritas ordens de Júpiter para, sob nenhum pretexto, nem se afastar do lugar nem abrir a boca até voltarmos. Então, apressadamente, rumamos para casa com a arca, tendo alcançado a cabana a salvo, mas depois de excessivo esforço, a uma hora da manhã. Esgotados como estávamos, ultrapassava as forças humanas fazer mais alguma coisa imediatamente. Descansamos até às duas horas e ceamos, partindo para as colinas logo depois, munidos de três resistentes sacos que havíamos encontrado, por felicidade, na cabana. Um pouco antes das quatro, chegamos ao buraco, dividimos o restante da presa, o mais igualmente possível, entre nós, e, deixando os buracos abertos, e de novo partimos para a cabana, na qual, pela segunda vez, depositamos nossas cargas de ouro, justamente quando os primeiros e fracos raios da madrugada apareciam a leste, luzindo por cima das copas das árvores.

Sentíamo-nos, agora, completamente esgotados, mas a intensa excitação daquele instante nos impedia de repousar. Depois dum sono inquieto dumas três ou quatro horas de duração, despertamos, como se o houvéssemos combinado, para proceder ao exame do nosso tesouro.

A arca fora cheia até as bordas e passamos o dia inteiro e grande parte da noite inventariando seu conteúdo. Nenhuma ordem ou arranjo fora adotada. Tudo fora amontoado misturadamente. Depois de tudo classificado com cuidado, achamo-nos de posse duma riqueza muito mais vasta do que a princípio supuséramos. Em moedas, havia mais, muito mais, de quatrocentos e cinqüenta mil dólares, estimando o valor do dinheiro, tão acuradamente como podíamos, de acordo com as tabelas da época. Não havia uma partícula de prata. Tudo era ouro de antiga data e de grande variedade: moedas francesas, espanholas e alemãs, com alguns guinéus ingleses e uns tantos miúdos, de que jamais havíamos visto modelos antes.

Havia muitas moedas bem grandes e pesadas, tão gastas que nada se podia vislumbrar de suas inscrições. Não havia dinheiro americano. Mais dificuldade encontrávamos em avaliar o valor das jóias. Haviam diamantes, alguns deles excessivamente grandes e belos, cento e dez ao todo , e nenhum pequeno; dezoito rubis de notável brilho; trezentas e dez esmeraldas, todas lindíssimas, e vinte e uma safiras, além de uma opala. Essas pedras tinham sido, todas, arrancadas de seus engates e atiradas de qualquer modo à arca. Os próprios engates que retiramos de entre outras peças de ouro pareciam ter sido batidos com martelos, como para 
impedir a identificação. Além de tudo isso, havia uma enorme quantidade de pesados ornamentos de ouro, quase duzentos brincos e anéis maciços; ricas correntes, em número de trinta, se bem me lembro; oitenta e três crucifixos muito grandes e pesados; cinco turíbulos de ouro de grande valor, uma maravilhosa poncheira de ouro, ornamentada com folhas de parreira ricamente cinzeladas e figuras báquicas; dois punhos de espada, caprichosamente gravados em relevo, e muitos outros objetos. menores, de que não me posso lembrar. O peso desses excedia de trezentas e cinqüenta libras, bem pesadas; e nessa avaliação eu não incluí cento e noventa e sete soberbos relógios de ouro, três dos quais valiam, cada um, quinhentos dólares, no mínimo. Muitos deles eram muito velhos e, para marcar o tempo, inúteis, pois o mecanismo sofrera, muito ou pouco, com a corrosão, mas eram todos ricamente cravejados de pedras, estando em estojos de alto preço.

Calculamos, naquela noite, que o inteiro conteúdo da arca valia um milhão e meio de dólares; e quando, depois, dispusemos dos berloques e jóias (retendo poucas para nosso uso próprio verificamos haver grandemente subestimado o tesouro. Ao concluir, por fim, nosso exame, diminuída de alguma intensa excitação daquelas horas, Legrand, que viu que eu morria de impaciência, esperando uma solução desse extraordinário enigma, passou a detalhar, completamente, todas as circunstâncias relacionadas com ele.

- Você se lembra - disse ele - da noite em que eu lhe entreguei o tosco desenho que fizera do scarabaeus. Você se recorda também, de que eu fiquei completamente zangado com você, de sua insistência de que meu desenho se assemelhava a uma caveira? Quando você pela primeira vez fez essa afirmativa, pensei que estivesse brincando; mas depois recordei as manchas características nas costas do inseto e concordei comigo mesmo em que sua observação tinha, de fato, alguma base. Contudo, a zombaria de minhas capacidades gráficas me irritou, pois sou considerado um bom artista, portanto, quando você me restituiu o pedaço de pergaminho, estive a ponto de rasgá-lo e atirá-lo, com raiva, ao fogo.

- O pedaço de papel, quer dizer - disse eu.

- Não, ele era muito parecido com o papel e, a princípio supus que fosse isso, mas quando fui desenhar nele verifiquei que era um pedaço de pergaminho muito fino. Você dsse que estava inteiramente sujo? Bem, quando eu estava a amarrotá-lo meu olhar caiu sobre o esboço para que você estivera olhando e você pode imaginar meu espanto quando, de fato, percebi a figura 
de uma caveira no mesmo lugar, pareceu-me, em que eu desenho do escaravelho. Por um momento fiquei demasiado atônito para pensar com clareza. Sabia que meu desenho era, em detalhes, muito diverso daquele, embora houvesse uma certa semelhança no contorno geral. Tomei então de uma vela e, sentando-me no outro canto do quarto, comecei a examinar o pergaminho mais perto. Depois de virá-lo, vi meu próprio desenho no verso, tal o havia feito. Minha primeira idéia, então, foi a de simples surpresa

pela similaridade de contorno realmente notável e pela sua singular coincidência envolvida no fato, para mim desconhecido, de que houvesse um crânio no outro lado do pergaminho, bem por trás de meu desenho do scarabaeur, e de que esse crânio, não só contorno, mas no tamanho, tão estreitamente se assemelhasse a meu desenho.

Digo que a similaridade dessa coincidência me deixou estupefato por algum tempo. Tal é o efeito comum de coincidências tais. A mente luta para estabelecer uma relação, uma seqüência de causa e efeito e, sendo incapaz de fazê -lo, experimenta uma espécie de paralisia temporária. Mas quando voltei a mim desse estupor, irrompeu em mim uma convicção, pouco a pouco, que me espantou mais do que a coincidência. Comecei distintamente, positivamente, a recordar que não havia desenho algum sobre o pergaminho quando fiz o esboço do escaravelho.

Fiquei perfeitamente certo disso, porque me lembrava de ter virado primeiro um lado e depois o outro, à procura do lugar mais limpo. Se o crânio tivesse estado ali, sem dúvida eu não podia ter deixado de notá-lo. Ali estava, de fato, um mistério que achei impossível explicar; mas mesmo naquele primeiro momento, pareceu-me cintilar, fracamente, no mais íntimo e secreto recanto de minha inteligência a larva de uma concepção daquela verdade de que a ventura da noite passada nos trouxe magnífica demonstração. Ergui-me logo e, guardando o pergaminho com cuidado, transferi toda reflexão ulterior para quando estivesse só.

Quando você saiu, e quando Júpiter estava já bem adormecido, entreguei-me a uma investigação mais metódica do assunto. Em primeiro lugar, considerei a maneira pela qual o pergaminho veio cair em meu poder. O lugar onde descobrimos o escaravelho era na costa do continente, a cerca de uma milha para leste da ilha, e apenas a curta distância acima da marca da maré alta. Quando o agarrei ele me deu uma aguda picada, o que me fez deixá-lo cair. 
Júpiter com sua precaução costumeira, antes de agarrar o inseto que voara para o lado dele, procurou em volta uma folha, ou algo semelhante, com que apanhá-lo.

Foi nesse momento que seus olhos e também os meus, caíram sobre o pedaço de pergaminho, que então supus ser papel. Ele estava meio enterrado na areia com uma ponta aparecendo. Perto do lugar onde o encontramos, observei os restos do casco do que parecia ter sido uma baleeira de navio. As ruínas pareciam estar ali desde muito tempo, pois nas madeiras mal se podia vislumbrar a aparência de um bote.

Bem, Júpiter apanhou o pergaminho, envolveu nele o escaravelho e deu- mo. Logo depois voltamos para casa e, no caminho, encontramos o Tenente $\mathrm{G}^{* * *}$.

Mostrei-lhe o inseto e ele me pediu que o deixasse levá-lo ao forte. Tendo o meu consentimento, colocou-o em seguida no bolso do colete, sem o pergaminho em que estivera enrolado e que eu continuara a ter na mão durante o tempo em que ele inspecionava o animal. Talvez receasse que eu mudasse de idéia e achasse melhor assegurar-se da presa imediatamente; você sabe quão entusiasta ele é em todos os assuntos relacionados com a História Natural. Ao mesmo tempo, sem notar o que fazia, eu devo ter cocado o pergaminho em meu próprio bolso.

Você se lembra de que, quando fui à mesa para o fim de fazer um esboço do escaravelho, não encontrei papel onde era ele habitualmente guardado. Procurei na gaveta e também nada achei. Revistei os bolsos, esperando encontrar uma velha carta, quando minha mão caiu sobre o pergaminho. Pormenorizo assim o modo preciso pelo qual este caiu em meu poder porque as circunstâncias impressionaram com força especial.

Não duvido de que você me achará um sonhador. Mas eu já estabelecera uma espécie de relação. Ajuntara dois elos de uma grande cadeia. Havia um bote jazendo sobre a costa marítima e não longe do bote, havia um pergaminho - não um papel - um crânio pintado nele. Você naturalmente perguntará: onde está a relação? Replico que o crânio, ou caveira, é o muito conhecido emblema dos piratas. A bandeira da caveira é içada em todas as suas empresas.

Já disse que aquele pedaço era de pergaminho e não de papel. O pergaminho é durável, quase imperecível. Raramente se confiam ao pergaminho coisas de pequena importância, visto 
como, para os simples fins ordinários do desenho ou da escrita, ele não se presta tão bem como o papel.

Essa reflexão sugeria algum significado, algum propósito na caveira. Não deixei de observar, também a forma do pergaminho. Embora um de seus cantos tivesse sido destruído por algum acidente, podia-se ver que a forma primitiva era quadrangular. Era justamente um pedaço, de fato, tal como poderia ter sido escolhido para uma nota, para o registro de alguma que devia ser prolongadamente lembrada e cuidadosamente preservada.

- Mas - interrompi -, você disse que o crânio não estava no pergaminho quando fez o

- desenho do escaravelho. Como, então traça alguma relação entre o bote e o crânio, desde que este último de acordo com o que você mesmo admitiu, deve ter sido desenhado (só Deus sabe como e por quem) em algum período subseqüente

ao de seu esboço do escaravelho?

- Ah, aí é que todo o mistério se resolve, embora, nesse ponto eu tivesse relativamente pouca dificuldade em resolver o segredo. Meus passos eram certos e eu só podia atingir um resultado. Raciocinei, por exemplo, assim: Quando desenhei o escaravelho, não aparecia crânio algum no pergaminho. Ao terminar o desenho, passei-o a você e observei-o acuradamente, até que você o devolveu. Você portanto, não desenhou o crânio e não se achava presente mais ninguém para fazê-lo. Logo, não fora feito por meios humano não obstante, fora feito.

Nesse ponto de minhas reflexões, esforcei-me por lembrar e lembrei, com inteira exatidão, todos os incidentes que correram por volta do período em apreço. O tempo estava frio (oh! Raro e feliz acaso!) e o fogo ardia na lareira. Eu me achava aquecido pelo exercício e senteime perto da mesa. Você, porém, puxara uma cadeira para perto da chaminé. Logo que coloquei o pergaminho em suas mãos, e que você estava a ponto de examiná-lo, Lobo, o meu terra-nova, entrou e pulou sobre seus ombros. Com a esquerda você lhe fez festas e com a direita, que segurava o pergaminho, caiu descuidadamente entre os seus joelhos, bem perto do fogo. Em um momento pensei que as chamas o atingissem e estava quase a avisá-lo quando, antes que tivesse podido falar, você o retirou e entregou-se a examiná-lo. 
Quando considerei todos esses pormenores, não duvidei um só momento de que o calor fora o agente que trouxera à luz, no pergaminho, o crânio que eu vira desenhado nele.

Você bem sabe que existem preparados químicos, e sempre existiram desde tempos imemoriais, por meio dos quais é possível escrever sobre papel ou velino, de modo que os caracteres só se tornem visíveis quando submetidos à ação do fogo. O óxido impuro de cobalto, dissolvido em água régia e diluído em quatro vezes o seu peso de água, é às vezes empregado; resulta uma tinta verde. O régulo de cobalto, dissolvido em espírito de nitro, dá uma tinta vermelha. Tais cores desaparecem em intervalos maiores ou menores, depois de efetuada a escrita, com o frio, reaparecem de novo, após a aplicação de calor.

Examinei então a caveira com cuidado. A borda exterior, a borda do desenho mais perto da ponta do velino, era bem mais distinta do que o resto. Claro estava que a ação do calórico fora imperfeita, ou desigual. Acendi fogo imediatamente e submeti todas as partes do pergaminho a um calor ardente. A princípio, o único efeito foi acentuar as linhas fracas do crânio; mas, perseverando na experiência ficou visível, num canto da faixa, diagonalmente, em oposição ao lugar em que se delineara a caveira, a figura do que, a princípio, supus ser uma cabra. Um exame mais acurado, contudo, demonstrou -me que se tratava de um cabrito.

- Ah! Ah! - disse eu. - Sem dúvida não tenho o direito de rir de você. Um milhão e meio em dinheiro é coisa muito séria para brincadeiras. Mas você não vai querer estabelecer um terceiro elo em sua cadeia. Você não vai achar uma relação especial entre seus piratas e uma cabra. Os piratas, como você sabe, não têm nada com as cabras; elas pertencem aos interesses dos fazendeiros.

- Mas eu acabo de dizer que a figura não era a de uma cabra...

- Bem, que seja de um cabrito... é mais ou menos a mesma coisa.

- Mais ou menos, mas não inteiramente - disse Legrand. - Você deve ter ouvido falar num tal Capitão Kidd. Pela minha parte, considerei logo a figura do animal como espécie de assinatura figurada ou hieroglífica. Digo assinatura porque sua posição no velino sugeriu essa idéia. A caveira no canto diagonalmente oposto tinha do mesmo modo, o aspecto de um 
sinete, ou selo. Mas fiquei tristemente perturbado com a ausência de mais qualquer coisa, de um corpo para meu imaginado documento, do texto de meu contexto.

- Presumo que você esperava encontrar uma carta entre o sinete e a assinatura. Algo dessa espécie.

- O fato é que me sentia irresistível impressionado com um pressentimento de alguma vasta e boa fortuna pendente. Mal posso dizer porque talvez, afinal de contas, fosse antes um desejo que uma crença real. Mas sabe você que as tolas palavras de Júpiter acerca de ser o escaravelho feito de ouro maciço tiveram notável efeito sobre minha imaginação? E, depois, a de acasos e coincidências. . . eram todos tão extraordinários! Observe! como, por simples acaso, esses acontecimentos ocorreram no único dia do ano que foi, ou podia ser, suficientemente frio para que acendêssemos fogo, e sem esse fogo, sem a intervenção do cão no momento preciso em que ele apareceu, eu nunca saberia da existência dessa caveira e, assim, nunca seria o possuidor do tesouro.

- Mas, continue. . . estou impaciente.

- Bem, você naturalmente já ouviu as muitas estórias que correm, esses mil boatos vagos que circulam acerca de dinheiro enterrado em algum ponto da costa atlântica por Kidd e seus associados. Tais boatos devem ter tido alguma base na realidade. E o fato de que eles tenham existido tanto e tão continuamente só podia ter resultado, pareceu-me, da circunstância de que o tesouro enterrado ainda permanecia sepulto. Tivesse Kidd escondido sua pilhagem por algum tempo, retirando-a depois, tais boatos raramente poderiam ter-nos alcançado na sua forma presente e invariável.

- Observe as estórias que se contam são, todas, sobre procuradores de dinheiro e não acerca de achadores de dinheiro. Se o pirata tivesse recuperado seu dinheiro, a questão estaria encerrada. Parece-me que aí algum acidente - digamos a perda de uma nota indicando o local - o privou dos meios de recuperar o tesouro e que esse acidente se tornou conhecido de seus comparsas, que de outro modo nunca poderiam ter ouvido falar, em absoluto, que o tesouro tivesse sido escondido, e que, empregando-se em tentativas inúteis, porque sem guia para reavê-lo, deram origem, primeiramente, e depois divulgação universal, aos relatos que agora 
são tão comuns. Você já ouviu falar que algum tesouro importante tenha sido desenterrado longo da costa?

- Nunca.

- Mas é bem sabido que a fortuna acumulada por Kidd era imensa.Tomei como certo, portanto, que a terra ainda a conservava escondida. E você mal se surpreenderá se lhe disser que senti uma esperança, quase chegando à certeza, de que o pergaminho estranhamente encontrado encerrasse o registro perdido do lugar do depósito.

- Mas como você continuou?

- Levei de novo o velino ao fogo, depois de aumentar o calor mas nada apareceu; julguei então possível que a cobertura de sujo podia ter alguma relação com o fracasso; assim, limpei cuidadosamente o pergaminho, derramando água quente sobre ele, e, tendo feito isso, coloquei-o numa caçarola de cobre com o crânio para baixo, e pus a caçarola sobre um fogão com carvão em brasa. Em poucos minutos a caçarola ficou inteiramente aquecida e removi a folha que, com indizível alegria, encontrei salpicada, em diversos com o que me pareceu serem figuras arrumadas em linhas. Coloquei-a de novo na caçarola e deixei que lá ficasse outro minuto. Depois de tirá-la, tudo estava tal como você agora vê.

- E aí Legrand, aquecendo de novo o pergaminho, entregou-o a meu exame. Entre a caveira e a cabra estavam toscamente traçados, em tinta vermelha, os seguintes sinais:

$.53 \% \%+305)) 6 * ; 4826) 4 \%>4 \%) ; 806 * ; 48+8 \& 60)) 85 ; 1 \%(;: \% * 8+83(88) 5 *+$

$46(; 88 * 96 * ? ; 8) * \%(; 485) ; 5 *+2: * \%(; 4956 * 2(5 *-4) 8 \& 8 * ; 4069285) ;) 6+8) 4 \% \%$;

$1 ;(\% 9 ; 48081 ; 8: 8 \% 1 ; 481 ; 48+85: 4) 485+528806 * 81(\% 9 ; 48 ;(88 ; 4(\% ? 34 ; 48) 4 \%$;

$161 ;: 188 ; \%$;

- Mas - disse eu, entregando-lhe a folha -, estou no escuro como antes. Esperassem-me todas as jóias de Golconda em troca da solução desse enigma e tenho plena certeza de que seria incapaz de ganhá-las. 
- E contudo- falou Legrand a solução de modo algum é tão difícil como você poderia ser levado a imaginar após o primeiro exame apressado dos caracteres. Esses caracteres, como qualquer pessoa pode prontamente verificar, formam uma cifra, isto é, encerram um significado; mas segundo o que se conhece de Kidd, eu não podia supô-lo capaz de compor qualquer espécie de cifra muito complicada. Achei, imediatamente, que esta era duma espécie simples, tal, entretanto, que para a inteligência rude do marinheiro devesse parecer absolutamente insolúvel, sem a chave. E você realmente a decifrou? Com toda a facilidade. Já decifrei outras, dez mil vezes mais complicadas. Certas circunstâncias e certas tendências do espírito levaram-me a interessar-me por semelhantes enigmas e pode-se bem duvidar de que a engenhosidade humana consiga compor um enigma dessa espécie, que a engenhosidade humana não possa decifrar, graças a uma aplicação adequada. De fato, uma vez que tenha eu arranjado caracteres unidos e legíveis, mal ligo importância à simples dificuldade de descobrir-lhe a significação.

- No caso presente - e na verdade em todos os casos de escrita secreta - a primeira questão diz respeito à língua da cifra, pois os princípios de solução, particularmente quando se trata das cifras mais simples, dependem do gênio de cada idioma e podem por isso variar. Em geral não há outra alternativa para quem tenta a decifração, senão experimentar (dirigido pelas probabilidades) cada língua conhecida até que a verdadeira seja encontrada. Mas nesta cifra que temos aqui diante de nós, toda a dificuldade foi removida, graças à assinatura. $\mathrm{O}$ trocadilho com a palavra "Kidd" só é perceptível na língua inglesa. Sem esta consideração, teria eu começado minhas tentativas com o espanhol e o francês, como línguas em que um segredo desta espécie deveria ter sido naturalmente escrito por um pirata dos mares espanhóis. Mas no caso presente, presumi que a cifra estivesse em inglês.

- Você há de notar que não existem divisões entre as palavra. Se as houvesse, a tarefa teria sido relativamente fácil. Em tal caso teria eu começado por fazer uma comparação e análise das palavras mais curtas e, se tivesse encontrado, como é sempre provável uma palavra duma só letra a (um) ou I (eu), por exemplo, haveria considerado a solução como garantida. Mas, não havendo divisões meu primeiro passo foi averiguar quais as letras dominantes, como as menos freqüentes.

Contando todas, construí a seguinte tábua: 


\begin{tabular}{|c|c|c|c|}
\hline $\mathrm{O}$ & algarismo & \multicolumn{2}{|c|}{8 ocorre 33 vezes } \\
\hline $\mathrm{O}$ & sinal $; o$ & \multicolumn{2}{|c|}{; ocorre 26 vezes } \\
\hline $\mathrm{O}$ & algarismo & 4 ocorre 19 & vezes \\
\hline $\mathrm{O}$ & sinal & $\%$ ocorre 16 & \\
\hline $\mathrm{O}$ & sinal )o & ) ocorre 16 & \\
\hline $\mathrm{O}$ & sinal $*$ occ & ocorre 13 & \\
\hline $\mathrm{O}$ & algarismo & 5 ocorre 12 & vezes \\
\hline $\mathrm{O}$ & algarismo & 6 ocorre 11 & vezes \\
\hline $\mathrm{O}$ & sinal & ocorre 10 vezes & \\
\hline $\mathrm{O}$ & sinal & + ocorre 8 & \\
\hline $\mathrm{O}$ & algarismo & 1 ocorre 8 & vezes \\
\hline $\mathrm{O}$ & algarismo & 0 ocorre 6 & vezes \\
\hline $\mathrm{O}$ & algarismo & 9 ocorre 5 & vezes \\
\hline $\mathrm{O}$ & \multicolumn{2}{|c|}{ algarismo 2 ocorre 5 vezes } & \\
\hline $\mathrm{O}$ & \multicolumn{2}{|c|}{ sinal : ocorre 4 vezes } & \\
\hline $\mathrm{O}$ & \multicolumn{2}{|c|}{ algarismo 3 ocorre 4 vezes } & \\
\hline $\mathrm{O}$ & sinal & ? ocorre 3 vezes & \\
\hline $\mathrm{O}$ & sinal \& & $\&$ ocorre 2 vezes & \\
\hline $\mathrm{O}$ & sinal & - ocorre 1 vezes & \\
\hline J & \multicolumn{2}{|c|}{ sinal . ocorre 1 vezes } & \\
\hline
\end{tabular}

- Ora, em inglês a letra que maisse encontra é o e. As demais ocorrem na seguinte ordem: a o i d h n r s t u y cf g $1 \mathrm{~m} \mathrm{w} \mathrm{b} \mathrm{k} \mathrm{p} \mathrm{q} \mathrm{x} \mathrm{z.} \mathrm{O} \mathrm{e} \mathrm{é} \mathrm{tão} \mathrm{singularmente} \mathrm{predominante} \mathrm{que} \mathrm{raras} \mathrm{são} \mathrm{as}$ frases, de certo tamanho, em que não seja ele a letra principal.Temos, pois, aqui, logo no começo, uma base para algo mais do que uma simples conjetura. É evidente o uso geral que se pode fazer dessa tábua, mas para esta cifra particular só mui reduzidamente nos utilizaremos de seu concurso. Como o algarismo predominante é o 8, começaremos por atribuir-lhe o valor de e, do alfabeto natural. Para verificar essa suposição, observemos se o 8 aí aparece muitas vezes aos pares, pois o e se duplica, com grande freqüência, em inglês: como, por exemplo, nas palavras meet, fleet, speed, seen, been, agree, etc. No caso presente, vemo-lo duplicada não menos de cinco vezes, embora o criptograma seja curto.

Admitamos, pois, que o 8 seja $\mathrm{O}$ e. Ora, de todas as palavras da língua, the é a mais usual. Vejamos, portanto, se não há repetições e três caracteres na mesma ordem de colocação, 
sendo o 8 o último dos três. Se descobrirmos repetições de tais letras arranja-das desta forma, elas representarão, mui provavelmente, a palavra THE. Examinando-se, encontramos não menos de sete dessas combinações; sendo os caracteres; 48. Podemos, portanto, supor que ; representa t, 4 representa h e 8 representa e, estando este último bem confirmado. De modo que um grande passo já foi dado. Tendo determinado uma única palavra, estamos capacitados a determinar um ponto vastamente importante, isto é, muitos começos e fins de outras palavras. Vejamos, por exemplo, o penúltimo que a combinação ;48 ocorre quase no fim da cifra. Sabemos que o sinal ; que vem logo depois é o começo de uma palavra dos seis caracteres que seguem este the conhecemos não menos de cinco. Substituamos, pois, estes caracteres pelas letras que já sabemos que eles representam, deixando um espaço para o que não conhecemos:t eeth.

Aqui já estamos habilitados a descartar-nos do th, como não formando parte da palavra que começa pelo primeiro t, pois que temos experimentando sucessivamente todas as letras do alfabeto para preencher a lacuna, que nenhuma palavra pode ser formada em que apareça esse th. Estamos, assim, limitados at ee,e percorrendo todo o alfabeto, se necessário, como antes, chegamos à palavra tree (árvore) como a única possivelmente certa. Ganhamos assim outra letra, o r, representada por (, e mais duas palavras justapostas, the tree (a árvore).Um pouco além destas palavras, a custa distância, vemos de novo a combinação; 48, e dela nos utilizamos como terminação da que imediatamente a precede. E assim temos este arranjo:the tree ; 4 (\% ?34 the,ou, substituindo pelas letras reais os sinais conhecidos, lê-se assim:the tree thr\%?3h the.

Ora, se em vez dos caracteres desconhecidos, deixarmos espaços em branco ou pontos que os substituam, leremos isto:the tree thr.The, a palavra through se torna imediatamente evidente. Mas esta coberta dá-nos três novas letras: o, u e g, representadas por \% e 3.Procurando agora, cuidadosamente, na cifra, combinações de caracteres conhecidos, descobrimos, não muito longe do princípio, disposição:83(88, ou seja, egree. Isto é, claramente, a conclusão da palavra degree (grau) e dá-nos outra letra, o d, representada por +.Quatro letras além da palavra degree notamos a combinação46; 88.

Traduzindo os caracteres conhecidos e representando os desconhecidos por pontos, como antes, vemos o seguinte:th rtee,combinação que sugere imediatamente a palavra trirteen (treze 
de novo nos fornece dois novos caracteres: i e n, representados respectivamente, por 6 e *.Voltando agora ao princípio do criptograma, observamos a combinação53\%\%+.

Traduzindo-a como antes, obtemos good.

Isso nos certifica de que a primeira letra é A e as primeiras palavras são: A good. É tempo,então, de organizar nossa chave com o já descoberto, em forma de uma tábua, para evitar confusões. Tê-la-emos assim:

$\begin{array}{ccc}5 & \text { representa } & \mathrm{a} \\ + & \text { representa } & \mathrm{d} \\ 8 & \text { representa } & \mathrm{e} \\ 3 & \text { representa } & \mathrm{g} \\ 4 & \text { representa } & \mathrm{h} \\ 6 & \text { representa i } & \\ * & \text { representa } & \mathrm{n} \\ \% & \text { representa } & \mathrm{o} \\ ( & \text { representa } & \mathrm{r} \\ ; & \text { representa } & \mathrm{t} \\ ? & \text { representa } & \mathrm{u}\end{array}$

- Temos, portanto, nada menos de onze das mais importantes letras representadas e será desnecessário continuar com os detalhes desta solução. Já lhe disse o bastante para convencêlo de que as cifras desta natureza são facilmente solúveis e para dar-lhe alguma idéia da análise racional que serve para desenvolvê-las. Mas fique certo de que o espécime presente pertence às mais simples espécies de criptogramas. Agora só resta dar-lhe a tradução completa dos caracteres do pergaminho, depois de decifrados. Aqui está ela:

"A goad glass in the bishap's hastel in the devil's seat forty one degrees and thirteen minutes northeast and by north main branch seventh limb east side shoot from the left eye of the death's-head a bee line from the tree through the shot fifty feet out.".

- Mas - disse eu - o enigma parece ainda em tão ma situação como antes. Como é possível extrair um significado dessa trapalhada toda de "cadeira do diabo", "caveira" e "hotel do bispo" ? 
(Um bom vidro no hotel do bispo na cadeira do diabo quarenta e um graus e treze minutos nordeste quadrante norte tronco principal sétimo galho lado leste atirai do olho esquerdo da caveira uma linha de abelha da arvore através o tiro cinqüenta pés distante.N. T.)

- Mas - disse eu - o enigma parece ainda em tão ma situação como antes. Como é possível extrair um significado dessa trapalhada toda de "cadeira do diabo", "caveira" e "hotel do bispo" ?

- Confesso - replicou Legrand - que a questão ainda apresenta um aspecto sério, quando encarada de modo superficial. Minha primeira tentativa foi dividir a sentença nas divisões naturais, pretendidas pelo autor da cifra.

- Pontuá-la, quer dizer?

- Mais ou menos isso.

- Mas como era possível fazê-lo?

- Refleti que o autor fizera questão de amontoar as palavras sem separá-las, para aumentar a dificuldade da tradução. Ora, um homem não demasiado esperto, ao objetivar tal resultado, quase certamente iria além do devido. Quando, no decorrer de sua escrita, a uma parada do assunto, que naturalmente requereria uma pausa ou mesmo um ponto, ele seria mais do que capaz de amontoar as letras nesse lugar, mais do que nas junções anteriores. Se você observar o manuscrito aqui presente, facilmente observará cinco casos de ajuntamento incomum. Partindo dessa sugestão, fiz a divisão seguinte:

A goad glass in the bishap's hastel in the devil's seat - forty one degrees and thirteen minutes -

northeast and by north - main branch seventh limb east side - shoot from the left eye of the death's-head

a bee line from the tree through the shot fifty feet out 
[Um bom vidro no hotel do bispo na cadeira do diabo - quarenta e um graus e treze minutos nordeste quadrante norte - tronco principal sétimo galho lado leste - atirai do olho esquerdo da caveira - uma linha de abelha da árvore através o tiro cinqüenta pés distante. N. T.)

-Mesmo esta divisão - falei - ainda me deixa no escuro.

- Também me deixou no escuro - replicou Legrand - por poucos dias, durante os quais fiz diligentes pesquisas nas vizinhanças de Sullivan, procurando algum edifício que tivesse o nome de " hotel do bispo", pois, naturalmente, não me inquietei com a palavra arcaica hostel. Não obtendo qualquer informação a respeito, estava a ponto de estender meu campo de pesquisa e proceder de modo mais sistematizado, quando, certa manhã, tive a bem súbita, de que esse "hotel do bispo" podia referir-se a antiga família Bessop, que, desde tempos remotíssimos, possuía mansão antiga a cerca de quatro milhas a nordeste da ilha.

Em conseqüência, fui até a fazenda e renovei minhas pesquisas entre os mais velhos negros do lugar. Afinal, uma das mulheres mais idosas disse que ouvira falar de um lugar tal como Bessop's Castle ( Castelo de Bessop) e achou que me podia levar ao lugar, mas que não se tratava de um castelo nem de uma taverna, mas de um rochedo elevado.

Ofereci-lhe boa paga pelo trabalho e, depois de alguma hesitação, consentiu em acompanharme ao local. Encontrando-o sem grande dificuldade, mandei-a de volta e passei a examinar o lugar. O "castelo" consistia num conjunto irregular de penhascos e rochedos, sendo um destes últimos muito digno de nota, por sua altura, bem como por sua aparência isolada e artificial. Subi a seu cume e fiquei sem saber o que devia fazer em seguida.

- Enquanto me ocupava em tal reflexão, caíram meus olhos sobre uma saliência estreita, na face ocidental do rochedo, uma jarda talvez por baixo do cimo em que me achava. Essa saliência projetava-se cerca de dezoito polegadas e não tinha mais de um pé de largura; um nicho no penhasco dava-lhe tosca semelhança como uma das cadeiras de encosto côncavo usadas por nossos antepassados.

- Não duvidei de que ali se achava a "cadeira do diabo" que aludia o documento e pareceume então apreender todo o segredo do enigma. 
- O "bom vidro", sabia eu, apenas podia referir-se a um binóculo, pois a palavra glass (vidro) é raramente empregada em outro sentido pelos marinheiros. Logo vi, então, que se devia usar um binóculo, de um ponto de visão definido, não admitindo variação. Não hesitei em acreditar que as frases "quarenta e um graus e treze minutos" e "nordeste quadrante norte" deveriam ser direções para colocação do binóculo. Grandemente excitado por essas descobertas apressei-me em voltar à casa, apanhei um binóculo e regressei ao rochedo.

- Coloquei-me na saliência e verifiquei que era impossível ficar sentado, a não ser uma posição especial. Esse fato confirmou minha idéia preconcebida. Passei a usar o binóculo. Naturalmente, "quarenta e um graus e treze minutos" só podiam aludir à elevação acima do horizonte visual, pois a direção horizontal estava claramente indicada pelas palavras "nordeste quadrante norte. Estabeleci imediatamente esta última direção, por meio de uma bússola de bolso; depois, apontando o binóculo a um ângulo de cerca de quarenta e um graus de elevação, como podia calcular por experiência, movi-o cautelosamente para cima e para baixo, até minha atenção foi detida por uma fenda circular, ou abertura, na folhagem de uma grande árvore, que, à distância, dominava suas companheiras. No centro dessa abertura percebi um ponto branco mas a princípio não pude distinguir de que se tratava. Ajustei o foco do binóculo, olhei de novo e verifiquei então que era crânio humano.

Depois desta descoberta, eu estava confiante em considerar o enigma resolvido, pois a frase "tronco principal, sétimo galho, lado leste" só se podia referir à posição do crânio na árvore, enquanto que "atirai do olho esquerdo da caveira" também apenas admitia uma interpretação em relação à busca do tesouro enterrado. Percebi que a intenção era de lançar uma bala através do olho esquerdo do crânio e que uma 'linha de abelha", ou, em outras palavras uma linha reta, tirada do ponto mais próximo da árvore através "do tiro", ou o lugar onde a bala caísse, e daí estendida a uma distância de cinqüenta pés, indicaria um ponto definido. E por baixo desse ponto considerei como pelo menos possível que estivesse oculto um depósito de valor.

- Tudo isso disse - é excessivamente claro e, embora engenhoso, simples e explícito. Que fez você depois de deixar o " hotel do bispo"? 
- Ora , tendo cuidadosamente tomado nota da aparência da arvore, voltei para casa. Logo, porém, que deixei a "cadeira do bispo" a abertura circular desapareceu. Não pude vê-la mais depois, embora me virasse para trás. O que pareceu a principal perícia, em todo esse negócio, foi o fato (pois repetidas experiências me convenceram de que era um fato) de que a abertura circular em questão não é visível de qualquer ponto de visão que se possa alcançar, a não ser o que permite a estreita saliência na face do rochedo. Nessa expedição ao "hotel do bispo", fora eu auxiliado por Júpiter, sem dúvida, observara, nas semanas anteriores, minha atitudes de abstração, tomando especial cuidado em não me deixar só. Mas no dia seguinte, levantando-me muito cedo, escapuli dele e fui às colinas, à procura da árvore. Depois de muito pesquisar, encontrei-a .

- Quando voltei para casa, à noite, meu criado estava resolvido a dar-me uma surra. Do resto das aventuras creio que você sabe como eu.

- Suponho - disse - que você errou o lugar, na primeira tentativa de cavar, por causa da estupidez de Júpiter, deixando o escaravelho cair pelo olho direito, em vez de pelo olho esquerdo do crânio

- Perfeitamente. Esse engano produziu uma diferença de cerca polegadas e meia no "tiro", isto é, na posição da cavilha mais próxima da árvore; e se o tesouro estivesse por baixo do "tiro" o erro teria sido de pouca importância; mas o "tiro", bem como o ponto mais próximo da árvore eram simplesmente dois pontos para o estabelecimento de uma linha de direção. Naturalmente o erro, embora trivial no começo, aumentava à medida que continuava com a linha e, ao completarmos os cinqüenta pés, ficamos inteiramente fora da direção. Não fossem minhas impressões solidificadas de que o tesouro estava ali realmente enterrado, em alguma parte, poderíamos ter perdido em vão todo o nosso trabalho.

- Mas sua grandiloqüência, sua conduta ao balançar o escaravelho... estavam enormemente extravagantes! Eu ficara certo de você enlouquecera. E por que você insistiu em deixar cair o escaravelho, em vez de uma bala, pelo crânio?

- Ora, para ser franco, eu me sentia algo aborrecido com suas evidentes suspeitas, relativamente à minha sanidade mental e resolvi castigá-los calmamente ao meu próprio jeito, com um pouquinho de calculada mistificação. Por esse motivo balancei o escaravelho, e por 
essa razão fiz com que fosse atirado da árvore observação sua sobre o grande peso dele sugeriu-me essa idéia.

- Sim, percebo! E agora só há um ponto que me embaraça. Que significam os esqueletos encontrados no buraco?

- Essa é uma pergunta a que não sou mais capaz de responder do que você. Parece, contudo, haver apenas um meio plausivel de explicar o caso. . . e, entretanto, é terrível acreditar em atrocidades tal como a implicada em minha hipótese. E claro que Kidd, (se na verdade Kidd escondeu esse tesouro, coisa de que não duvido)claro que ele deve ter sido auxiliado nesse trabalho. Concluído, porém, o serviço, pode ter ele considerado prudente fazer desaparecer todos os que participavam de seu segredo. Talvez um par de golpes com uma picareta, fosse suficiente, enquanto seus ajudantes se ocupavam em cavar; talvez fossem necessários doze. . . Quem sabe? 


\section{ATIVIDADES}

Atividade 1: Bilhete Secreto

$\begin{array}{cccccccccccccccc}\text { O } & \text { U } & \text { D } & \text { L } & \text { S } & \text { R } & \text { M } & \text { G } & \text { N } & \text { R } & \text { L } & \text { O } & \text { S } & \text { I } & \text { M } \\ \text { L } & \text { E } & \text { O } & \text { U } & \text { E } & \text { A } & \text { O } & \text { O } & \text { O } & \text { A } & \text { H } & \text { E } & \text { T } & \text { O } & \text { U } \\ \text { A } & \text { R } & \text { S } & \text { N } & \text { N } & \text { R } & \text { S } & \text { R } & \text { M } & \text { V } & \text { O } & \text { M } & \text { E } & \text { S } & \text { N } \\ \text { Q } & \text { I } & \text { A } & \text { O } & \text { T } & \text { E } & \text { A } & \text { A } & \text { A } & \text { I } & \text { S } & \text { I } & \text { R } & \text { O } & \text { D } \\ & & & & & & & & & & & & & & \\ \text { O } & \text { R } & \text { O } & \text { F } & \text { I } & \text { I } & \text { M } & \text { O } & \text { I } & \text { S } & \text { A } & \text { A } & \text { V } & \text { O } & \text { E } \\ \text { D } & \text { I } & \text { G } & \text { I } & \text { N } & \text { A } & \text { O } & \text { S } & \text { N } & \text { T } & \text { C } & \text { T } & \text { E } & \text { C } & \text { M } \\ \text { A } & \text { P } & \text { R } & \text { A } & \text { I } & \text { R } & \text { S } & \text { S } & \text { V } & \text { I } & \text { A } & \text { R } & \text { S } & \text { I } & \text { A } \\ \text { C } & \text { T } & \text { A } & \text { E } & \text { C } & \text { E } & \text { N } & \text { A } & \text { E } & \text { G } & \text { O } & \text { A } & \text { D } & \text { N } & \text { B }\end{array}$

a) Qual é a mensagem oculta nela?

b) Como você a descobriu?

c) Utilizando a mesma lógica, criptografe a seguinte mensagem: "No meio da dificuldade, encontra-se a oportunidade". Albert Einstein

d) Você considera esse código com um nível de segurança alto ou baixo? Justifique.

Atividade 2: Debate sobre o filme

Algumas questões norteadoras para o debate sobre o filme:

- o momento histórico da humanidade; o perfil psicológico de Alan Turing e similaridades com outras pessoas;

- a questão da homossexualidade e da intolerância na Inglaterra e no mundo;

- reflexos das relações sociais;

- revolução científica (uso da enigma e a criação de Christopher);

- disputas em torno da verdade; algoritmos e resolução de problemas;

- o que é criptografia;

- panorama do século XX;

- o papel do Matemático nesse período;

- importância da criptografia naquele período histórico; 
- Criptografia no século XXI.

Atividade 3: "Guerras da Gália de Júlio César"

“ O mensageiro recebeu instruções para que, se não pudesse se aproximar, jogasse uma lança com a mensagem amarrada por uma tira de couro, dentro das fortificações do campo... Com medo, o gaulês arremessou a lança como fora instruído. Por acaso a arma encravou-se em uma torre e passou dois dias sem ser vista pelos nossos soldados, até que, no terceiro dia, um soldado a viu, retirando-a e entregando a mensagem para Cícero. Ele a leu e depois a recitou em voz alta para a tropa em formação, trazendo grande alegria para todos”. (Singh, p. 26)

O que será que essa mensagem quer dizer?

\section{OLJHLUD UDSRVD PDUURP VDOWRX VREUH R FDFKRUUR FDQVDGR}

Responda,

a) Como você a descobriu?

b) Seria possível, estabelecer uma "fórmula" para criptoanalisar a mensagem? Explique.

c) Existe uma "fórmula" para criptografar a mensagem?Explique.

d) Que palavras são essas? Criptoanalise-as.
121134113411
33114415331144241311

e) Quais as semelhanças entre Código de Políbio e a Cifra de Júlio César? Qual parece mais segura? Justifique.

f) Escreva um bilhete para a dupla vizinha, utilizando a cifra de César.

Atividade 4: Desafio de criptoanálise

JGMG G GKS HULD PMENSGQ
a) Qual é o significado dessa frase? É possível criptoanalisá-la? Justifique.
b) Quais são os aspectos positivos e negativos da Cifra de Vigenère?
c) Quais os pontos em comum da Cifra de Blaise de Vigenère e as mensagens escritas pela máquina Enigma?


Atividade 5: Cifra Indecifrável

a) Agora é a sua vez de criar uma cifra indecifrável. Para tal, você deve levar em consideração:

- Será uma cifra de transposição ou substituição?

- Qual será a regra para cifrar? Explique-a. (Obs.: Precisa ter uma lógica de construção, como as cifras analisadas).

- Dê um nome para a sua cifra.

- Dê exemplos de criptografia e criptoanálise da cifra criada.

Registre todos os dados de sua cifra nessa folha.

b)Elabore uma maneira criativa de apresentar sua cifra para a turma.

c) Apresente sua Cifra para a turma (combinar data de apresentação e tempo de duração).

Atividade 6: Pesquisa

Pesquise sobre a Máquina Enigma e sua lógica de funcionamento. Registre nessa folha suas descobertas e observações que julgar pertinente sobre a descoberta, sempre relacionando com as discussões feitas em sala.

Atividade 7: Avaliação das Atividades

Que bom:

Que pena:

Que tal: 